\section{Pacific Northwest}

National Laboratory

Operated by Battelle for the

U.S. Department of Energy

\title{
Hydrologic Characterizations Using Vadose Zone Monitoring Tools: Status Report
}

\author{
G.W. Gee \\ A.L. Ward \\ Pacific Northwest National Laboratory \\ Richland, Washington \\ J.B. Sisson \\ J.M. Hubbell \\ Idaho National Engineering and Environmental Laboratory \\ Idaho Falls, Idaho \\ D.A. Myers \\ H.A. Sydnor \\ CH2M Hill Hanford Group \\ Richland, Washington
}

February 2003

Prepared for the U.S. Department of Energy under Contract DE-AC06-76RL01830 


\title{
DISCLAIMER
}

This report was prepared as an account of work sponsored by an agency of the United States Government. Neither the United States Government nor any agency thereof, nor Battelle Memorial Institute, nor any of their employees, makes any warranty, express or implied, or assumes any legal liability or responsibility for the accuracy, completeness, or usefulness of any information, apparatus, product, or process disclosed, or represents that its use would not infringe privately owned rights. Reference herein to any specific commercial product, process, or service by trade name, trademark, manufacturer, or otherwise does not necessarily constitute or imply its endorsement, recommendation, or favoring by the United States Government or any agency thereof, or Battelle Memorial Institute. The views and opinions of authors expressed herein do not necessarily state or reflect those of the United States Government or any agency thereof.

\author{
PACIFIC NORTHWEST NATIONAL LABORATORY \\ operated by \\ BATTELLE \\ for the \\ UNITED STATES DEPARTMENT OF ENERGY \\ under Contract DE-ACO6-76RLO183O
}

This document was printed on recycled paper. 


\title{
Hydrologic Characterization Using Vadose Zone Monitoring Tools: Status Report
}

G. W. Gee
A. L. Ward
Pacific Northwest National Laboratory
Richland, Washington

\author{
J. B. Sisson \\ J. M. Hubbell \\ Idaho National Engineering and Environmental Laboratory \\ Idaho Falls, Idaho \\ D. A. Myers \\ H. A. Sydnor \\ CH2M HILL Hanford Group \\ Richland, Washington
}

February 2003

Prepared for the U.S. Department of Energy

under Contract DE-AC06-76RL01830

Pacific Northwest National Laboratory

Richland, Washington 99352 


\section{Summary}

Hydrologic characterization of the vadose zone (from soil surface to the underlying water table) is needed to assess contaminant migration from buried wastes. The Pacific Northwest National Laboratory, under contract with the U. S. Department of Energy's EM-50 (Subsurface Contamination Focus Area), and in collaboration with CH2MHILL Hanford Group, the Idaho National Engineering and Environmental Laboratory (INEEL), and Duratek Federal Services (DFS), deployed a suite of vadose-zone instruments at the Hanford Site near Richland, Washington. Several new instruments were tested. One instrument, the Advanced Tensiometer (AT), developed at INEEL measures soil water pressures in the vadose zone, and was tested successfully at a Hanford field site by both auger placement and by drive cone (penetrometer) methods. Another new instrument, the water fluxmeter, adapted by Battelle from conventional lysimeter technology, measures drainage flux directly, and was successfully tested and subsequently deployed at Hanford and a number of other sites including the Savannah River Site (SRS). The purpose of the vadose zone deployments was to obtain in situ hydrologic characterization data, to verify drainage potential and to obtain estimates of current recharge fluxes under a range of surface conditions.

A series of tests to confirm performance and longevity of vadose zone monitoring sensors has been ongoing since 1999. Data have been archived and updated on a current web page, http://vadose.pnl.gov. The results reported on the web page from tests at the VZFS300N field site indicate that the tensiometer systems have been reliable and have required little or no servicing for periods up to three years or longer, for all sensors tested. A nearly continuous record has been maintained since sensor installation. The site contains a set of $7.6 \mathrm{~m}$ deep lysimeters, designed to simulate waste burial-ground conditions. The tensiometer data exhibit unit-gradient conditions confirming that drainage persists at the site in spite of the arid climate. The data also clearly show that for bare sand surfaces water pressure pulses generated by net infiltration of winter rains are dampened with depth and do not appear to penetrate below $3 \mathrm{~m}$, so that near steady-state drainage conditions prevail below this depth. Water storage measurements in the top 1 meter appear to capture most of the transient changes in water content within the sediment profile. Measured drainage for the past three years has averaged about $55 \mathrm{~mm} / \mathrm{yr}$, similar to predictions using past measurements from a drainage experiment where instantaneous profile data of water contents and soil water pressures were taken on an adjacent lysimeter. Estimates of drainage or recharge using textural analysis, laboratory methods, and a permeameter method used in previous studies, have been less successful in predicting actual drainage. The data suggest that direct measurements of drainage either by water fluxmeter or by profile monitoring (instantaneous methods) may be required to obtain reliable estimates of the water flux and related hydraulic properties of Hanford sediments.

Two deployments within the Hanford Site Tank Farms were completed. The first was in FY 2001,

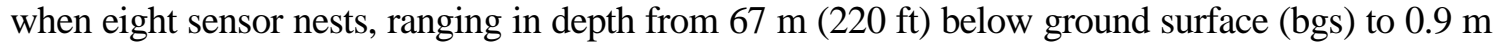
(3 ft) bgs were placed in contact with vadose-zone sediments inside an uncased borehole (C3360) located adjacent to Tank B-110. The sensor sets are part of the Vadose Zone Monitoring System (VZMS) for the Hanford Tank Farms and include advanced tensiometers, heat dissipation units, water content reflectometers, thermal probes, and solution samplers. Within the top meter of the surface, a water 
fluxmeter was deployed to directly measure net infiltration from meteoric water (rain and snowmelt) sources. In addition, a rain gage was located within the Tank Farm to document on-site precipitation events. All sensor units, with the exception of the solution samplers, were connected to a solar-powered data logger located within the B Tank Farm. Data collected from these sensors were accessed by modem and cell phone. Tensiometer data collected to date show that unit gradient conditions have persisted at the B Tank Farm site since installation of the instruments more than a year ago. The persistence of unitgradient conditions supports the case for drainage at this site. The gravel surfaces and lack of vegetation on the Tank Farm promotes accumulation of water in the surface that enhances drainage. The tensiometer data show the vertical direction of water flow and indicate that drainage is occurring but the data do not provide a direct measure of drainage rates, which can only be estimated if the unsaturated hydraulic conductivity of the sediments is known. The water fluxmeter provides a direct measure of drainage from meteoric water sources (or surface water spills that might occur directly over the fluxmeter) The fluxmeter was calibrated in late March 2002 and indicated that it was responding properly to water inputs. Since the seasonal precipitation has been below normal little drainage has occurred during the spring and summer of 2002 in these coarse sediments. Thermal profiles from the sensor nests appear normal and show little effect of heating due to radioactivity in the subsurface. Solution samples collected from the subsurface by a vacuum lysimetry system are currently being analyzed.

The second deployment of vadose-zone hydrologic sensors was in FY 2002, when four sensor nests ranging in depth from $30.1 \mathrm{~m}$ (98 feet) to $1.5 \mathrm{~m}$ (5 feet) bgs were placed in an uncased borehole (C3830) located between Tank TX 101 and TX 105 in the TX Tank Farm. Because of the reduced size of the borehole $(0.18 \mathrm{~m}$ for the TX borehole vs. $0.26 \mathrm{~m}$ for the B borehole), the sensor sets were limited to advanced tensiometers and thermocouples placed at each of four depths. Also, due to drilling restrictions, water fluxmeters were placed outside the Tank Farm. Two water fluxmeters were placed under coarse gravel surfaces, directly south of the TX borehole C3830 just outside the fenced perimeter of the Tank Farm. Data collected from the sensor nests and fluxmeters are currently being accessed remotely. Data from the TX Tank Farm has been placed online at a secure website. Tensiometer data collected from the TX Tank Farm are similar to those at the B Tank Farm and indicate that unit-gradient conditions exist and the Tank Farm is draining. Water fluxmeter data collected over the course of the next three years will be made available to estimate drainage rates within the TX Tank Farm.

Data from vadose-zone monitoring provide direct measures of soil water pressures, temperatures, and water fluxes. Vadose-zone monitoring can document waste site responses to changes in meteoric inputs of precipitation (rain and snowmelt), to assess the impacts of water-line leaks, or support ex-tank leak detection during retrieval operations. Since most flux rates in the vadose zone are relatively low and changes generally occur slowly, results will not be instantaneous. Meaningful data sets will require an extended monitoring period (several years or more). Based on current observations, however, data from the tensiometers indicate that drainage is occurring within the two monitored Tank Farms at the Hanford Site. Similar drainage conditions are expected at other Tank Farms at Hanford, where surfaces are coarse-textured and bare. As multiple years of data are collected, hydrologic monitoring systems with water fluxmeters will be able to provide a direct measure of annual recharge within Tank Farms and other waste sites, thus providing an early warning to the potential of future groundwater contamination. 


\section{Acknowledgments}

The work described in this report was funded by the U. S. Department of Energy (DOE) under Contract DE-AC06-76RL01830. The DOE Office of Science and Technology, Subsurface Contamination Focus Area, supported the Tank Farm work. The Tank Farm deployments were successful because of excellent cooperation by CH2M HILL Hanford Group, who allowed boreholes in B and TX Tank Farms to be used for hydrologic monitoring purposes. The characterization boreholes are part of a CH2MHILL activity supported by the U. S. Department of Energy's Office of River Protection (ORP) through the Tank Farm Vadose Zone Project. We thank Tony Knepp of CH2M HILL Hanford Group and Rob Yasek, Department of Energy-ORP, for providing windows of opportunity for these deployments. We also acknowledge the help of Kent Reynolds and Dave Skoglie of Duratek Federal Services in the instrument package design and placement. We thank Joe Lord of Idaho National Engineering and Environmental Laboratory; Ray Clayton, John Goreham, Chris Strickland, and Jennifer Carr of Pacific Northwest National Laboratory (PNNL); and Jason Ritter (formerly of PNNL, now at Campbell Scientific, Inc., Logan, Utah), all of whom provided installation support for the instrumentation deployments or computer support for the work described in this report. We also thank tank-farm operations supportstaff for assistance in sensor placement. The initial tests on the Advanced Tensiometers and the water fluxmeter were supported by DOE's Laboratory Directed Research and Development (LDRD) program, the Groundwater Vadose Zone Integration Project Science and Technology program, and Project RL31SS31. 


\section{Acronyms}

\begin{tabular}{|c|c|}
\hline AT & Advanced Tensiometer \\
\hline bgs & below ground surface \\
\hline CH2MHILL & CH2M HILL Hanford Group \\
\hline $\mathrm{CPT}$ & Cone Penetrometer Technology \\
\hline CSI & Campbell Scientific Inc., Logan, Utah \\
\hline DCT & Drive Cone Tensiometer \\
\hline DFS & Duratek Federal Services \\
\hline DOE & U. S. Department of Energy \\
\hline FFTF & Fast Flux Test Facility \\
\hline $\mathrm{HDU}$ & Heat Dissipation Unit \\
\hline HMS & Hanford Meteorological Station \\
\hline INEEL & Idaho National Engineering and Environmental Laboratory \\
\hline LDRD & Laboratory Directed Research and Development \\
\hline ORP & Office of River Protection \\
\hline PNNL & Pacific Northwest National Laboratory \\
\hline PVC & Polyvinyl chloride \\
\hline SRS & Savannah River Site \\
\hline VZFS & Vadose Zone Field Site \\
\hline VZMS & Vadose Zone Monitoring System \\
\hline WFM & Water Fluxmeter \\
\hline
\end{tabular}




\section{Contents}

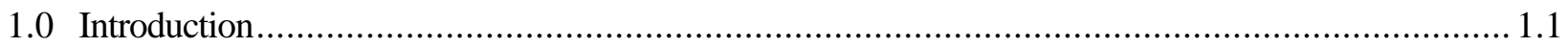

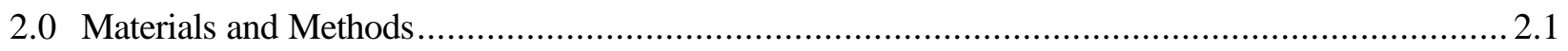

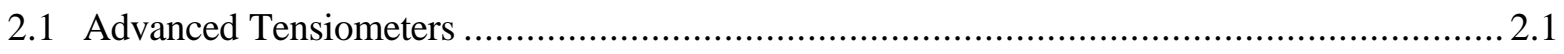

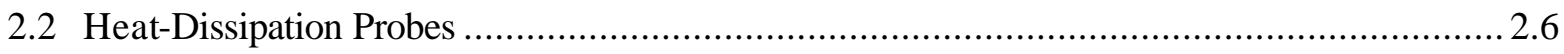

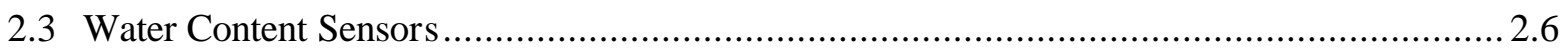

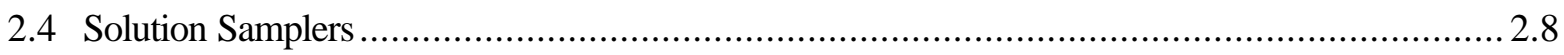

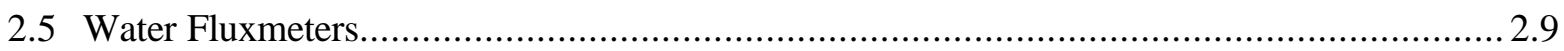

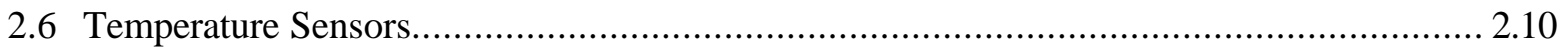

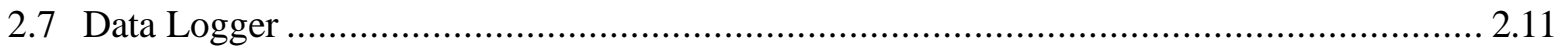

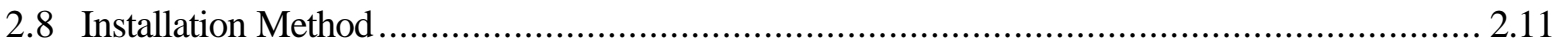

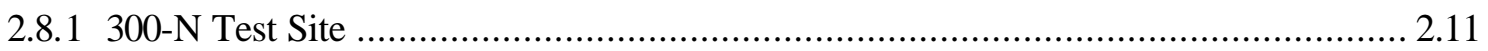

2.8.2 B Tank Farm-Borehole C3360 ................................................................ 2.12

2.8.3 TX Tank Farm- Borehole C3830 and Water Fluxmeter Placements ....................... 2.17

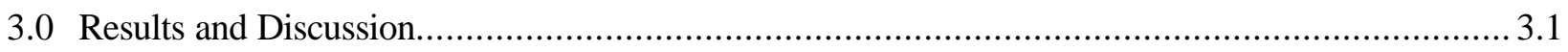

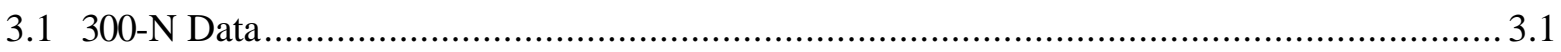

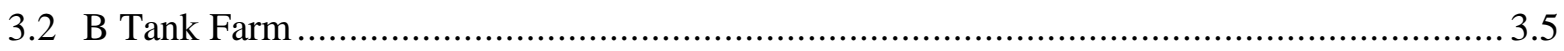

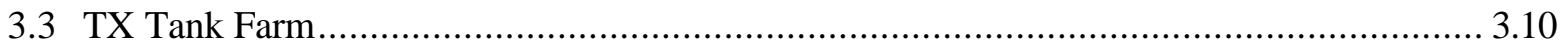

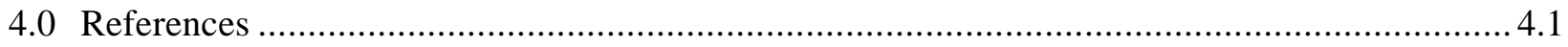

Appendix A: Duratek Water Well Report for C-3360 (299-E33-46) ............................................ 1

Appendix B: Water Well Report for TX Tank Farm Borehole C3830 ….................................. B.1

Appendix C: Water Well Report for Tank Farm TX Water Fluxmeters-

Geotechnical Borings C4089 and C4090.......................................................... C.1 


\section{Figures}

2.1. Schematic of ATs Showing the Porous Cup and Pressure Transducer System for a Typical Deployment

2.2. Drive Cone Tensiometer (DCT) Deployed at the VZFS300N Site Using Cone Penetrometer Technology (CPT)

2.3. Picture of a DCT for Directly Pushing Sensor into Sediments, Without Auger Drilling, Using CPT.

2.4. AT Modified for Tank Farm Placement

2.5. Heat Dissipation Unit (HDU) for Measuring Soil Water Pressures

2.6. Campbell Scientific CS-615 Water Content Reflectometer. CS-615 units were installed in the $300 \mathrm{~N}$ Lysimeter to measure soil-water storage in the top meter.

2.7. Schematic of Modified CS-505 (CSI Logan, Utah) Water Content Sensor for Placement in the Tank Farm Borehole C-3360 at near B-110.

2.8. VZMS (Without Water Fluxmeter and Temperature Sensor) Before Deployment in B Tank Farm

2.9. Schematic View of the PNNL WFM

2.10. Schematic of the 300-N Lysimeter Site Showing the North and South Lysimeter and Locations of Auger-Placed and CPT-Placed Tensiometers.

2.11. View of B Tank Farm in the 200 E Area, Hanford Site, Washington, in July 2001 During the Drilling of Borehole C3360

2.12. Installation of VZMS System in Borehole C3360 at B Tank Farm in 200 E Area Hanford Site, July, 2001

2.13. Completion of Well C3369 Showing Coarse-Gravel Surface and Top of the Water Fluxmeter ..... 2.15

2.14. Data Aquisition System, Including Solution Sensor Lines, Data Logger, Solar Panel, and Raingage, Located Adjacent to Completed Borehole C3360 next to Tank B-110 in B Tank Farm, 200 E Area.

2.15. View of the TX Tank Farm in $200 \mathrm{~W}$ Area, Hanford Site, Washington, During Installation of Borehole C3830 in September 2002. Borehole C3820 is located near Tank TX-105. 
2.16. Schematic of Sensor Placement in Borehole C3830, Located near Tank TX-105 and the Water Flux Meter Installation Located at the Periphery of the Tank Farm South of TX-101....... 2.19

2.17. Placement of AT in Borehole C3830 at TX Tank Farm, September, 2002.............................. 2.20

2.18. Placement of Sand Slurry in Borehole C3830 in TX Tank Farm, September 2002................... 2.21

3.1. Time Course of Soil Water Pressure as Measured with Auger-Placed ATs at the 300-N Lysimeter Site

3.2. Time Course of Soil Water Pressure as Measured with Drive-Cone Placed Tensiometers (DCTs) at the 300-N Lysimeter Site

3.3. Total Head vs. Depth for 300 North.

3.4. Water Balance for 300 North

3.5. Soil Water Pressure Data: (a) Shallow and (b) Deep Sensors . 3.7

3.6. Total Head at Well C3360

3.7. Water Content in Borehole C3360, near Tank B-110, from August Through October, 2001 3.8

3.8. Drainage as Measured by the Water Fluxmeter......

3.9. Near Surface Soil Temperature Changes over Time

3.10. Soil Temperature Changes over Time at Depth.

3.11. AT Data at Borehole C3830 TX Tank Farm. Soil Water Pressure.

3.12. Hydraulic Head Data at Borehole C3830 in TX Tank Farm.

3.13. Temperature Data at Borehole C3830 in TX Tank Farm

\section{Table}

3.1. VZMS Sensor Placement in Borehole C3360 near Tank B110 in B Tank Farm. 3.5 


\subsection{Introduction}

Millions of curies of radioactive waste currently reside in the vadose zone at the U. S. Department of Energy's Hanford Site near Richland, Washington (Gephart and Lundgren 1998, Gephart 2001). While much of the radioactivity is immoblizied in Hanford sediments, a portion, including ${ }^{99} \mathrm{Tc}$, remains mobile in the Hanford vadose zone and has now reached groundwater in elevated concentrations. For example, in the SX Tank Farm at one monitoring well near SX-115, ${ }^{99} \mathrm{Tc}$ in groundwater has increased to more than 63,000 pCi/L, over 70 times regulatory limits (Johnson and Chou 2001). Predictions of quantities and timing of the arrival of radioactive and hazardous contaminants to groundwater rely on computer models which in turn require as inputs, estimates of the hydraulic properties of Hanford sediments. The more reliable the inputs, the better the model predictions. Because of this, there is increasing interest to obtain improved characterization of hydraulic properties and also to obtain field mesurements of both flow and transport for history-matching purposes, leading to model calibration and verification. Such detailed characterization work has just begun at the Hanford Site. The Pacific Northwest National Laboratory, under the Office of Science and Technology's Subsurface Contaminant Program was directed to develop and test vadose-zone monitoring methods for hydraulic propertiy characaterization at the Hanford Site. Collaborators on this project have included the Idaho Engineering and Environmental Laboratory (INEEL), CH2M HILL Hanford Group (CH2MHILL) and Duratek Federal Services (DFS). This report provides a status of that effort.

Hydraulic property characterizaion within the vadose zone includes such measurements as soil water pressure, water content, hydraulic conductivity and water flux. Knowledge of the water-potential gradient and hydraulic conductivity allows the calculation of water flux over the interval of measurement in a soil profile. Direct measurement of the water flux, in turn, can be used to estimate the hydraulic properties if the water-potential gradients are known. Such data combinations indentify the dominant flow direction in the vadose zone and can be used to quantify recharge rates, a requirement for successful interpretation of existing contaminant plumes, for history matching in model calibration and for predicting future migration rates. Under ideal conditions, such information is easily obtained by monitoring water content and water pressure. In some cases, the water flux can be directly measured during controlled infiltration experiments. Because of costs and worker safety, this approach is not readily applicable at contaminated sites within the U.S. Department of Energy (DOE) complex, and more innovative techniques are needed to obtain this information. Water-flow direction is best determined from water-potential gradients measured using tensiometry. However, traditional tensiometers are limited to operating within a few feet from the ground surface and are often fragile, difficult to install and expensive to maintain, particularly at depth in contaminated sites. Advanced tensiometers, developed initially at the INEEL, as described later in more detail, overcome these limitations. They are more robust, more easily maintained, and can be placed at almost any depth below ground surface. The addition of water content and water-flux measurements to water pressure provide a very strong suite of measurements useful for estimating recharge rates and rates of chemical transport. When linked to a data-acquisition and telemetry system, these sensors provide realtime measurements of changes in water pressure and water contents. These data, when correlated or linked to water-flux measurements, changes in surface boundary conditions, and episodic changes in groundwater contamination levels, allow important driving forces and transport 
mechanisms in the Hanford vadose zone to be identified. A combination of sensors packaged as a vadose-zone monitoring-system (VZMS), designed to measure the water balance, pressure gradients, and related parameters, can provide a site with necessary characterization data for evaluating vadose-zone transport.

In keeping with the overall objectives of the Department of Energy's EM 50 Subsurface Contaminant Focus Area, project RL31SS31 (Hanford Vadose Zone Characterization-Flow and Transport Processes) and in support of the vadose zone characterization effort being conducted within the Hanford Tank Farms (CH2MHILL 2000), the work reported here has focused on both developing and deploying instrumentation and methods that can be used to improve the hydrologic characterization of the vadose zone at the Hanford Site. A key area where hydrologic characterization information is currently needed is at Tank Farms where leaks of high-level waste fluids have occurred. One objective of this project was to deploy suitable vadose-zone sensors for hydrologic characterization within Tank Farms at Hanford. To accomplish this objective, Pacific Northwest National Laboratory (PNNL) teamed with CH2MHILL, INEEL, and DFS, and installed VZMS within the B Tank Farm in the 200 E Area and the TX Tank Farm of the $200 \mathrm{~W}$ Area of the Hanford Site during FY 2001 and FY 2002. The following sections describe the specific sensors used, initial tests conducted, and subsequent deployments in the B and TX Tank Farm including final in-place sensor configurations, monitoring strategies and initial results. 


\subsection{Materials and Methods}

In situ hydrologic characterization of the vadose zone has evolved over the past few years to include key measurements of water content, soil water pressure, temperature, and chemical concentration. Knowledge of these state variables is essential to developing a more complete understanding of vadosezone processes and provides dynamic input to numerical model calibration and verification efforts. In addition to the state variables, soil-water-flux data are also needed. The VZMS is used to measure the hydrologic parameters described above. While the VZMS does not provide chemical concentrations directly, soil water samples are obtained by means of vacuum lysimeters that can remove samples at depth, and the pore waters are taken to the laboratory for analysis. Recent developments also have allowed water flux in the vadose zone to be monitored more easily. Because no single sensor is capable of monitoring all of the key variables in the vadose zone, a suite of sensors is required in the VZMS. Using a number of sensors allows for concurrent measurements of state variables and also provides the characterization and monitoring data needed to further identify flow paths and mechanisms that previously may not have been considered in transport models. We describe in turn sensors that are currently being used in the VZMS for the Hanford Site.

\subsection{Advanced Tensiometers}

A tensiometer is simply a water-filled porous cup attached hydraulically to a pressure transducer. The porous cup is placed in contact with subsurface sediment, and water inside the cup is allowed to equilibrate with pore water in the sediment. In unsaturated sediments, a vacuum (negative pressure) is created inside the cup equal to the soil water pressure at the cup surface. The pressure transducer produces a voltage output directly related to the negative pressure in the cup, thus registering the soil water pressure of the sediment (or matrix). A tensiometer is a key vadose-zone monitoring device, because it is the only instrument we are aware of that can directly measure soil water pressure. Under typical conditions, the tensiometer has an operational range from 0 mbar to -700 mbar. Tensiometers can also be used to measure positive pressures in soils that are saturated and thus act as piezometers for monitoring perched water bodies or water-table elevations.

ATs incorporate the pressure transducer directly into the porous cup to minimize the length of the water column that hydraulically connects the pressure transducer to the cup (Sisson and Hubbell 1999). By minimizing the water-column length, the ATs' performance is enhanced by eliminating (or minimizing) several problems encountered in conventional tensiometers-namely, excessive thermal noise, sluggish response, and limited depth placement (Hubbell and Sisson 1996, 1998; Sisson and Hubbell 1999). Placement of the pressure transducer, porous cup, and the water column at depths where diurnal temperature fluctuations are dampened minimizes the problem of thermally affected fluid movement into and out of the tensiometer. Placement of the pressure transducer directly in contact with the cup reduces the chance for air entrapment in line with the transducer, thus minimizing the lag time for pressure response. In addition to reducing the noise level from temperature fluctuations, the length of time between refilling the tensiometer can be extended from once per week to once per year or longer, depending on the 
depth of placement and the in situ soil water pressures. The short length of the sealed portion of the AT makes it possible to be placed at almost any depth (Figure 2.1). The pressure transducer is typically a hermetically sealed unit that can either operate in absolute or differential mode and gives a linear millivolt output over a range of 0 to \pm 1000 mbar.
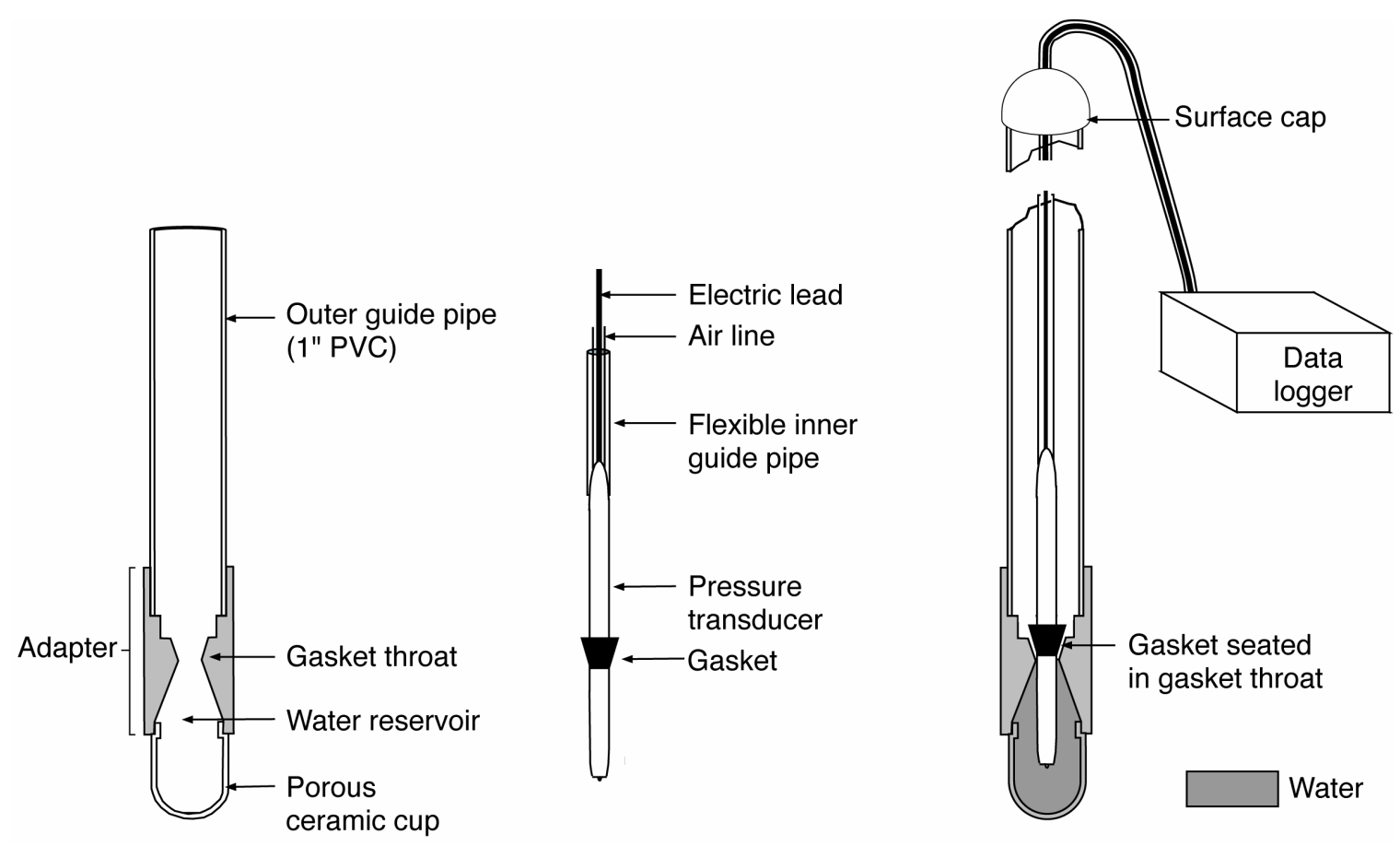

Figure 2.1. Schematic of ATs Showing the Porous Cup and Pressure Transducer System for a Typical Deployment

ATs have been deployed successfully at a number of sites, including INEEL, Savannah River, Oak Ridge, and Hanford. Technical issues with respect to the durability of sensors, data-acquisition systems, and reliability of data have largely been resolved. Typically, sensors have been easily installed under conditions where monitoring points have been relatively easy to access. The major technical issue for Hanford relates to deployment into contaminated sites and in deep vadose-zone materials (deeper than

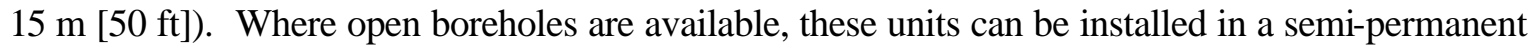
installation. An option to placement of tensiometers in boreholes is to modify the AT so that it can be deployed by use of cone penetrometer (CPT) techniques. Such a direct push system has been successful at the Hanford Site (Sisson et al. 2002) and is shown in Figure 2.2 and Figure 2.3

The AT design for the Hanford Site Tank Farms was modified from Figure 2.1, based on observations that soil water pressures in Hanford sediments are generally within the range of 0 to -100 mbar and also that access to tensiometers in the Tank Farms is limited so that refilling operations need to be minimized. In wet soils, water losses from the tensiometer cups should be very low such that the life of the units can be extended almost indefinitely in draining sediments by increasing the volume of water in the tensiometer. Wet sand and similar coarse-grained sediments are present in abundance in the subsurface at most Hanford waste sites. Figure 2.4 shows a schematic of the modified ATs used for Tank Farm deployments. 
It should be noted that the AT units deployed in the B tank farm are slightly different from the "singleshot" unit shown in Figure 2.4, which was used for the TX tank farm deployment. For the B tank farm deployment, the pressure sensor was placed in the cup and the electrical leads were brought out of the top plug. Some tests on ATs similar to the B tank farm have shown that the vacuum seal on the lead wires is not always perfect leading some slow loss of vacuum and malfunction of the AT units where the wires are brought through the top plug. This issue will be discussed in the results section of the report.

\section{During Installation}

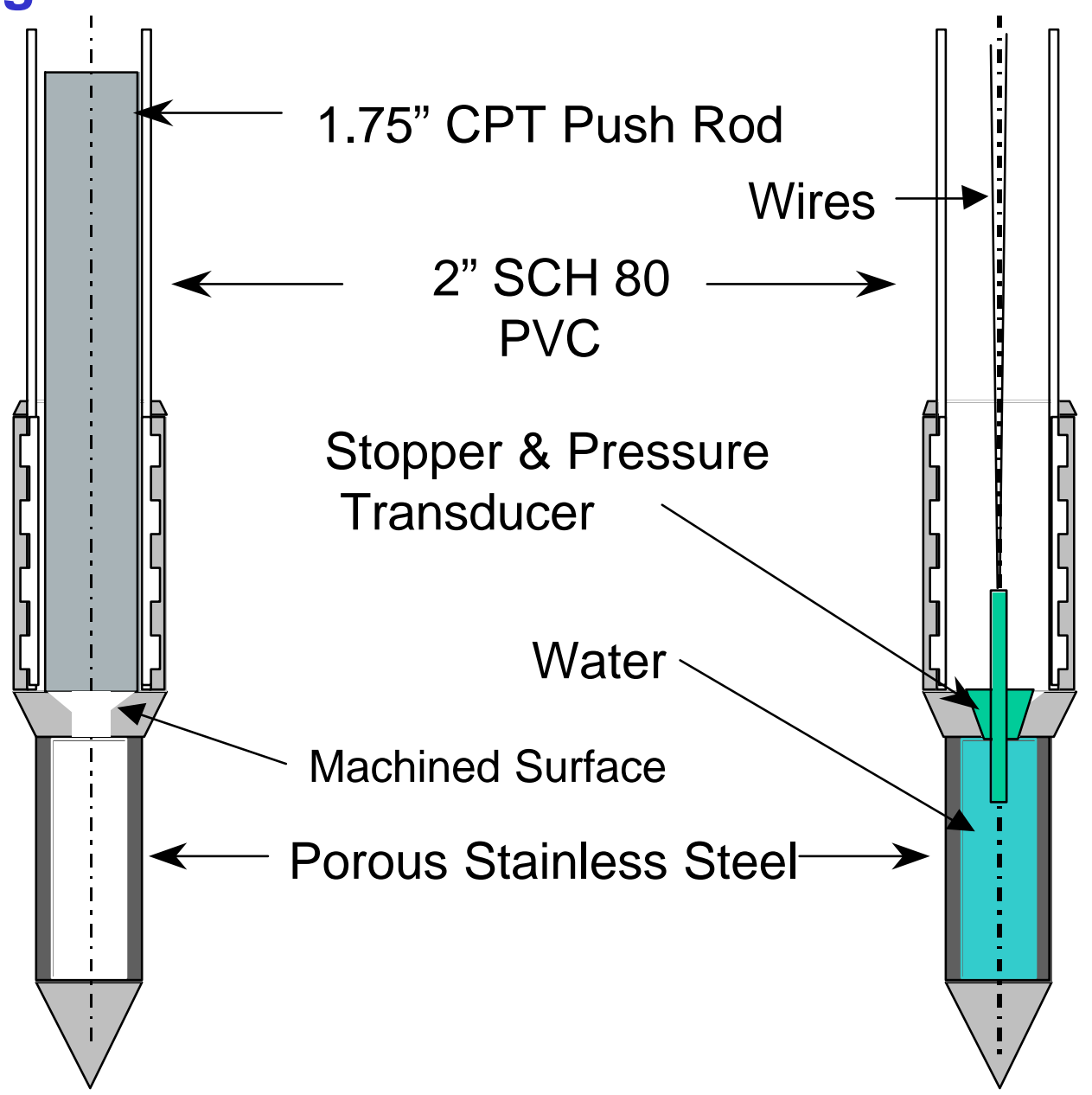

Figure 2.2. Drive Cone Tensiometer (DCT) Deployed at the VZFS300N Site Using Cone Penetrometer Technology (CPT). The DCT is placed in the ground by a hydraulic push technique and requires no open borehole. The depth of placement is limited by formation resistance to CPT push, which for Hanford Site conditions is typically less than $30 \mathrm{~m}$. 


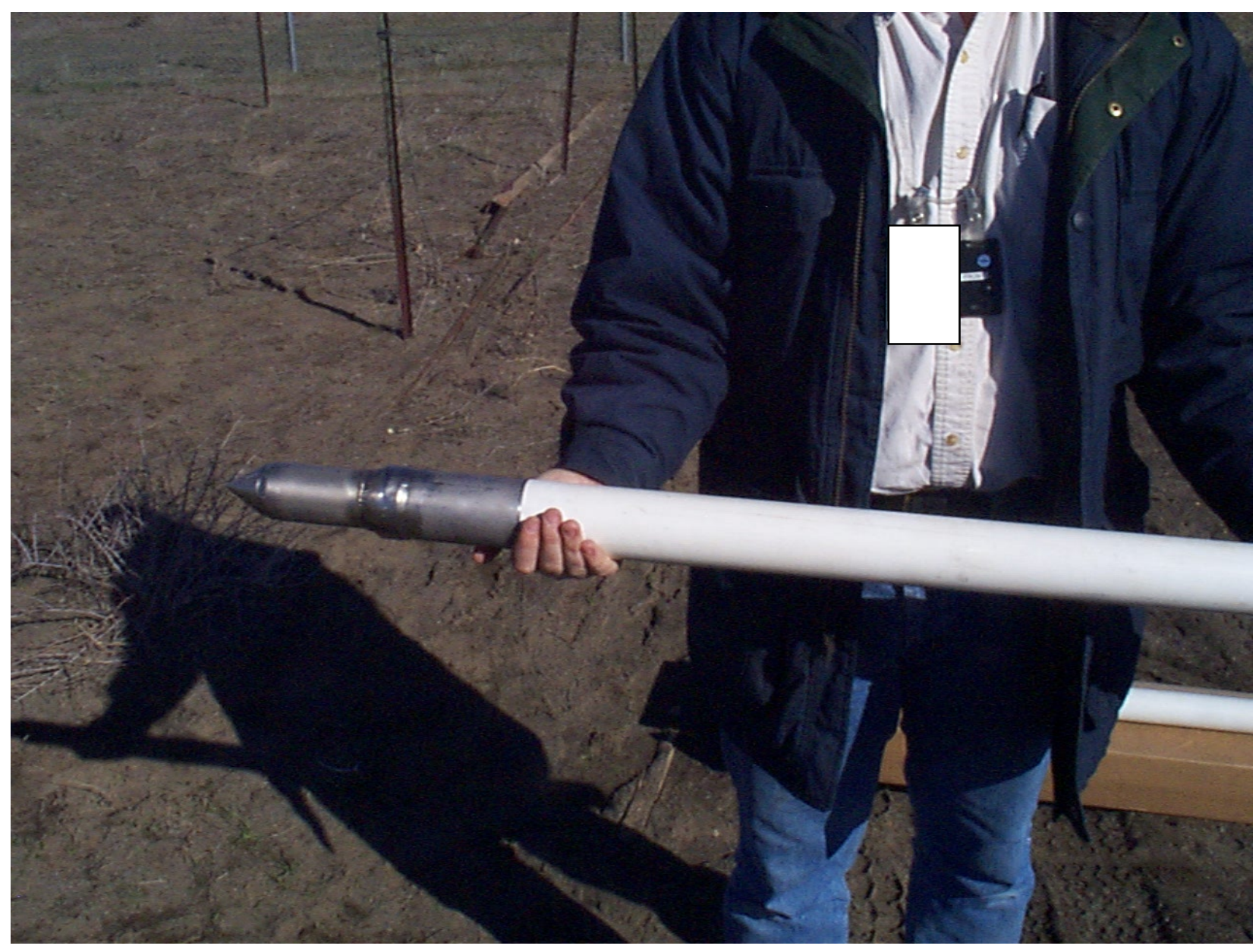




\section{Single Shot Tensiometer}

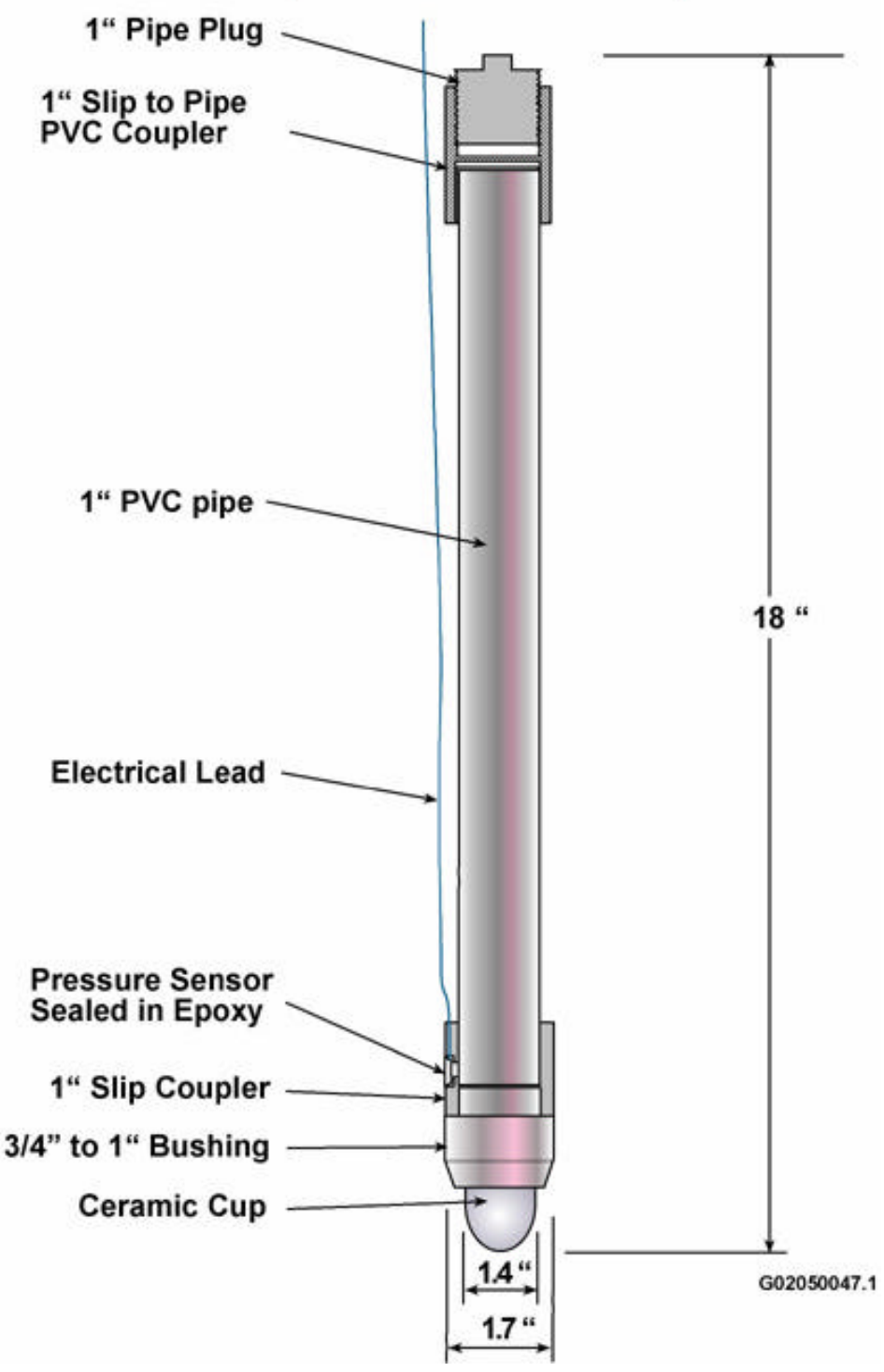

Figure 2.4. AT Modified for Tank Farm Placement

For Tank Farm deployments, the AT configuration is a simply a ceramic cup attached to a sealed, water-filled plastic (PVC) tube. The total water volume in the tube and cup is approximately $0.4 \mathrm{~L}$. The outer and inner guide pipe that normally extends to the land surface is eliminated so that only electrical connections are brought to the surface. The pressure transducer used in the tensiometer is a type that can over-range beyond the typical pressure limit of 1000 mbar (15 psi). The pressure sensor (Motorola MPX4250A, Denver, Colorado) is placed adjacent to the measurement location so that when the unit is sealed and a vacuum is established, the pressure measurement is a direct measure of the soil water pressure. The pressure range of the sensor also allows for detection of perched water if the sediments become saturated. 


\subsection{Heat-Dissipation Probes}

The heat-dissipation unit (HDU) is used to measure soil water pressure and is commercially available from CSI, Logan, Utah (e.g., model 229 L). The HDU consists of a special ceramic body with a temperature sensor and a heater imbedded in the center (Figure 2.5).

A short heat pulse is generated in the porous ceramic, and the heat dissipation is related to the water content of the ceramic, which in turn is related uniquely to the water pressure in the surrounding media . Reece (1996) has shown that these units are quite reliable in the pressure range from -100 mbar to -10000 mbar or more. The HDU provides a redundant measure of soil water pressure and operates in a range beyond where the normal tensiometers operate (i.e., 0 to -700 mbar). HDUs have been used successfully at Hanford in the $200 \mathrm{E}$ Area to measure water pressures in silt loam soils that cover the prototype surface barrier (Ward et al. 1997). It is expected that these units will work best in soils that have drained such that their soil water pressures are drier than -100 mbar (the typical air entry value for the porous ceramic). The HDUs were calibrated in the laboratory using Hanford sediments at three different water contents.

\subsection{Water Content Sensors}

Water content sensors used in the tests reported here were electronic reflectometers (frequency domain-type) made by Campbell Scientific, Inc. (CSI), Logan, Utah. In the initial tests in the 300 Area, CSI model CS-615s (Water Content Reflectometers) were used to monitor water storage in the top meter of the sediment profile (Sisson et al. 2002). The CS-615 unit measures the effective dielectric (electrical properties) of the soil between two metal rods spaced about $5 \mathrm{~cm}(2 \mathrm{in}$.) apart. The rods for

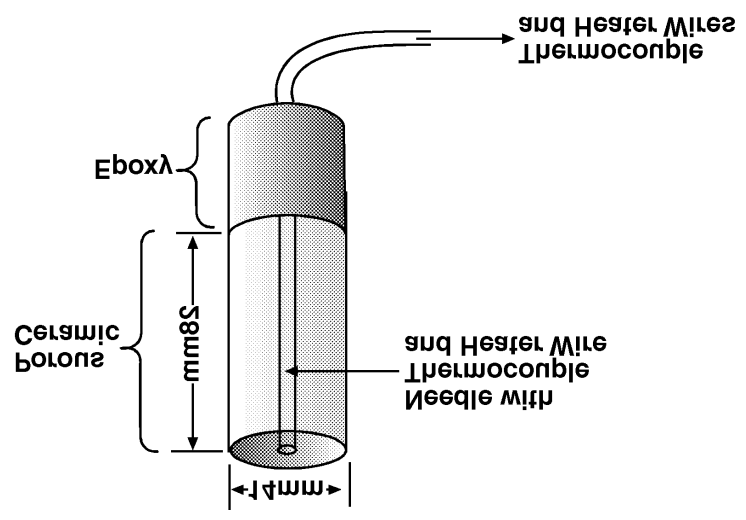
these commercial units are $30 \mathrm{~cm}$ (12 in.) long.

Figure 2.5. Heat Dissipation Unit (HDU) for Measuring Soil Water Pressures

Figure 2.6 shows a CS-615 unit, typical of those installed at the 300 Area test site. In loose sands and alluvial silt deposits, these units can simply be pushed into the formation. In gravels and coarse materials, the units need to be placed so that the rods remain uniformly spaced, so excavation and backfilling are typically required. The units are calibrated by measuring voltage output as a function of soil water content (reported on a volume basis). The electronic circuitry for the CS-615 reflectometers is imbedded into the plastic end piece and is hermetically sealed (Figure 2.6). The units are weather resistant and typically expected to have a long service life (multiple years). According to CSI, the major failure mode is a lightning strike that can short out the electronics, but with proper grounding, this problem can be avoided. We have experienced no failures of any CS-615 probes at the Hanford Site during our more than 3 years of testing. 


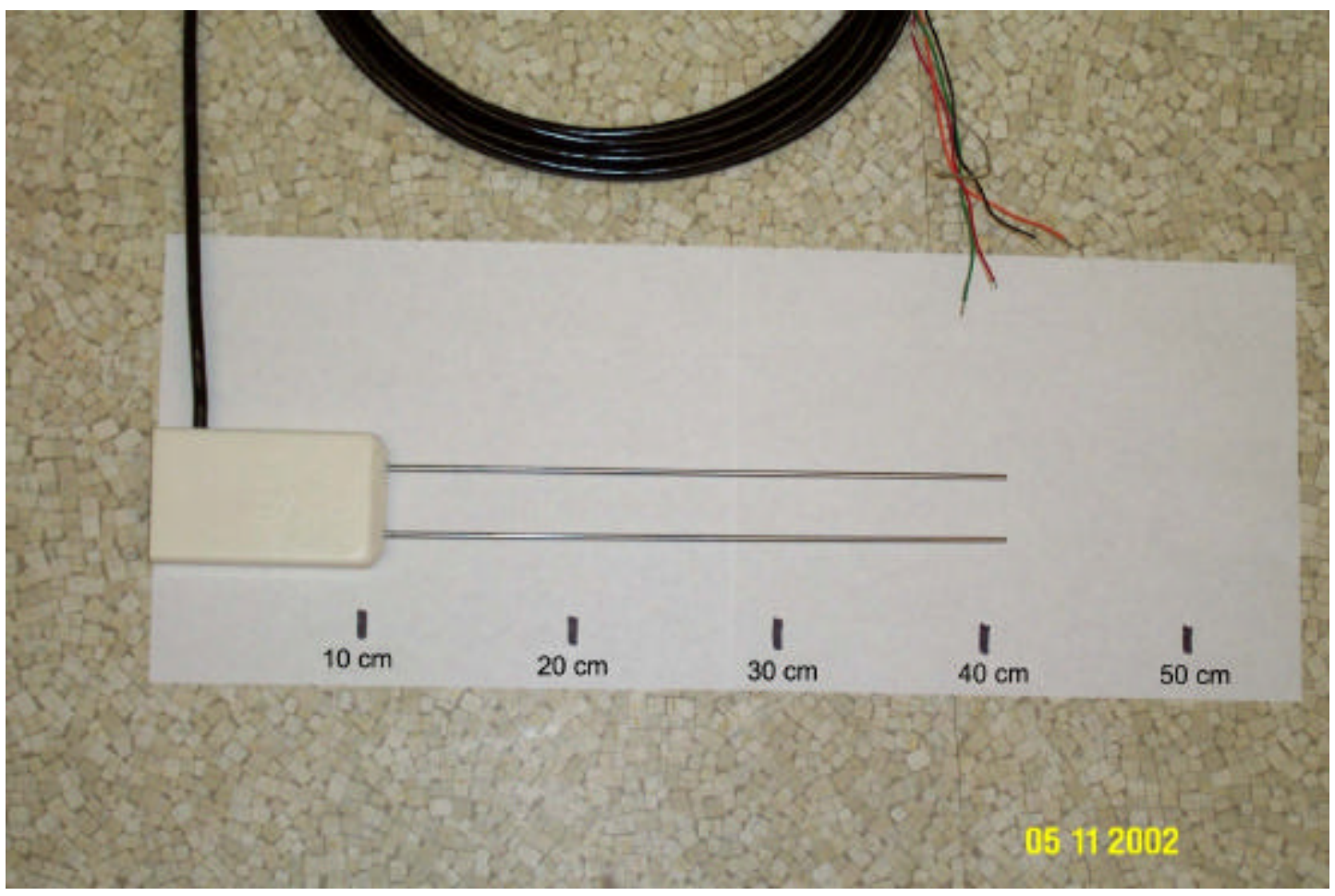

Figure 2.6. Campbell Scientific CS-615 Water Content Reflectometer. CS-615 units were installed in the $300 \mathrm{~N}$ Lysimeter to measure soil-water storage in the top meter.

In tank-farm boreholes, the water-content measurement is more complicated. The borehole is filled with backfill, and the sensors must make direct contact with the formation. If they are imbedded in the backfill, they will reflect the water content of the backfill, which in general will be quite different from that of the formation. For example, when fine silica sand (e.g., SCS-90, U. S. Silica, Ottawa, IL) is used as backfill, the water content can be as high as 30 vol. \% or more, while the formation water content is generally a fraction of that (often less than $10 \mathrm{vol} . \%$ ). This is because the pore-size distribution and water-retention characteristics of the backfill and the formation materials are strikingly different (e.g., fine silica flour vs coarse-grained sediments). Dissimilar materials with widely differing pore-size distributions in contact with each other can achieve pressure equilibrium, but for rather obvious reasons, they never achieve water-content equilibrium. For use in the borehole, water-content sensors were fabricated using a CS-505 fuel-moisture sensor (Campbell Scientific, Logan, Utah) attached to brass electrodes mounted on a foam backing material. The water-content sensor is lowered to depth, and the electrode-foam-pad assembly is forced against the borehole wall with a lever arm is a schematic of the water-content assembly.

The water-content sensors were calibrated in Hanford sediments obtained at the VZFS300N lysimeter site in the 400 Area, Hanford, Washington. The calibration procedure consisted of packing the sensors in a 15.9-cm (6.25-in.) diameter column of oven-dried sediments, obtaining a sensor output, saturating the column using tap water, and then obtaining another sensor output. The two outputs were used to compute a linear calibration for each sensor. 


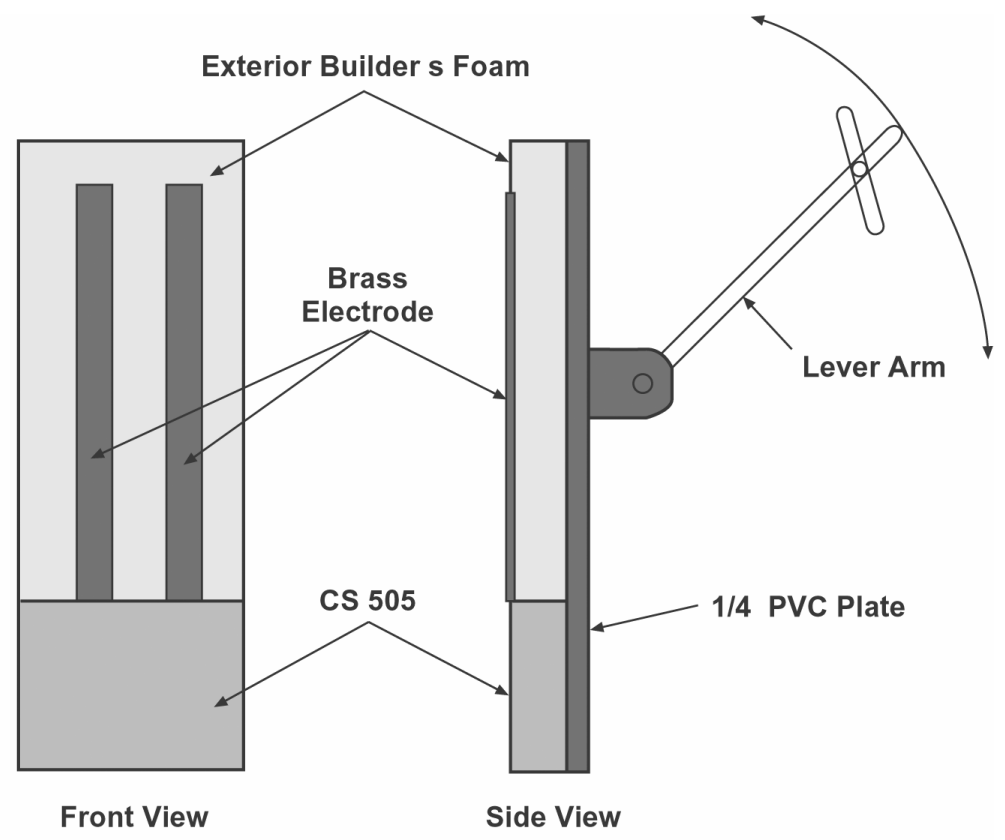

Modified CS 505

Water Content Sensor

G03010057-2

\section{Figure 2.7. Schematic of Modified CS-505 (CSI Logan, Utah) Water Content Sensor for} Placement in the Tank Farm Borehole C-3360 at near B-110

\subsection{Solution Samplers}

The solution samplers are model 1940 solution samplers constructed with 1-bar high-flow ceramic cups (Soil Moisture Equipment Co., Santa Barbara, California). These sampling units were constructed with the upper end of the ceramic sealed with a plug that accommodates two $0.635-\mathrm{cm}(0.25$-in.) plastic lines. The lines, which extend to the soil surface, run to an environmental box that is located beneath the data logger. The lines are used for pressurization and sample collection. When solution samples are to be collected, a negative pressure is applied for a given period of time (e.g., $0.5 \mathrm{~h}$ or longer, dependant on field conditions), and then the line is pressurized to remove the water sample. This pressure forces the liquid sample out of the cup and up into a collection system at the surface. Figure 2.8 shows the VZMS system before installation in the B Tank Farm at Well C3360 with the full array of instruments. Not shown in the picture are the temperature sensor and the water fluxmeter that is described in the following section. 


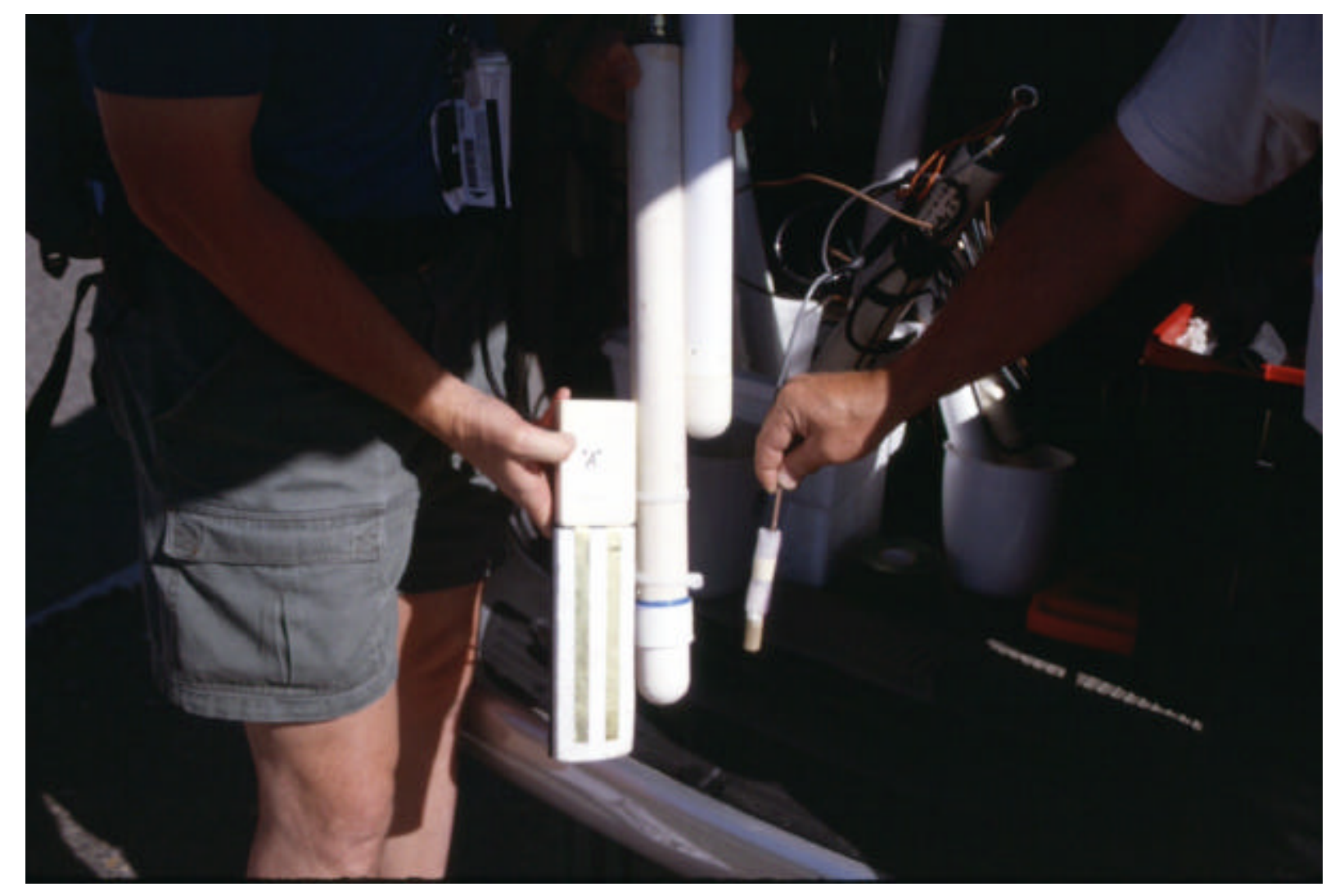

Figure 2.8. VZMS (Without Water Fluxmeter and Temperature Sensor) Before Deployment in B Tank Farm. Sensors from left to right are the modified CSI water content sensor, AT, solution sampler, and HDU.

\subsection{Water Fluxmeters}

Figure 2.9 shows an idealized cross section of the PNNL water fluxmeter (WFM). The WFM is essentially a continuously recording, miniature drainage-lysimeter (Gee et al. 2002a). The WFM unit allows the draining water to percolate into a fiberglass wick that has a tension control of about 60-mbar soil water pressure. The tension control and the extension of soil above the wick combine to limit the diversion of water around the meter, which is often one of the limitations of such lysimeter units. A tipping-spoon rain gage (Rain-O-Matic, Pronamic Co. Ltd, Sikeborg, Denmark) collects and records the drainage water. The rain gage is hooked to an event recorder and measures drainage-water volume on a nearly continuous basis (Figure 2.9). The bottom of the WFM unit was installed in the borehole at about the 1.8-m (6-ft) depth. For Tank Farm applications, the top of the unit at the B Tank Farm was initially about $20 \mathrm{~cm}$ (8 in.) bgs from the surface and covered with gravel fill. No vegetation is growing on the Tank Farm surface, so significant drainage from winter precipitation is expected to occur at this site. The fluxmeter will provide the net infiltration data needed to determine the rate of flux in the near surface throughout the year. The WFM unit will require some time to equilibrate with the surrounding sediments. 


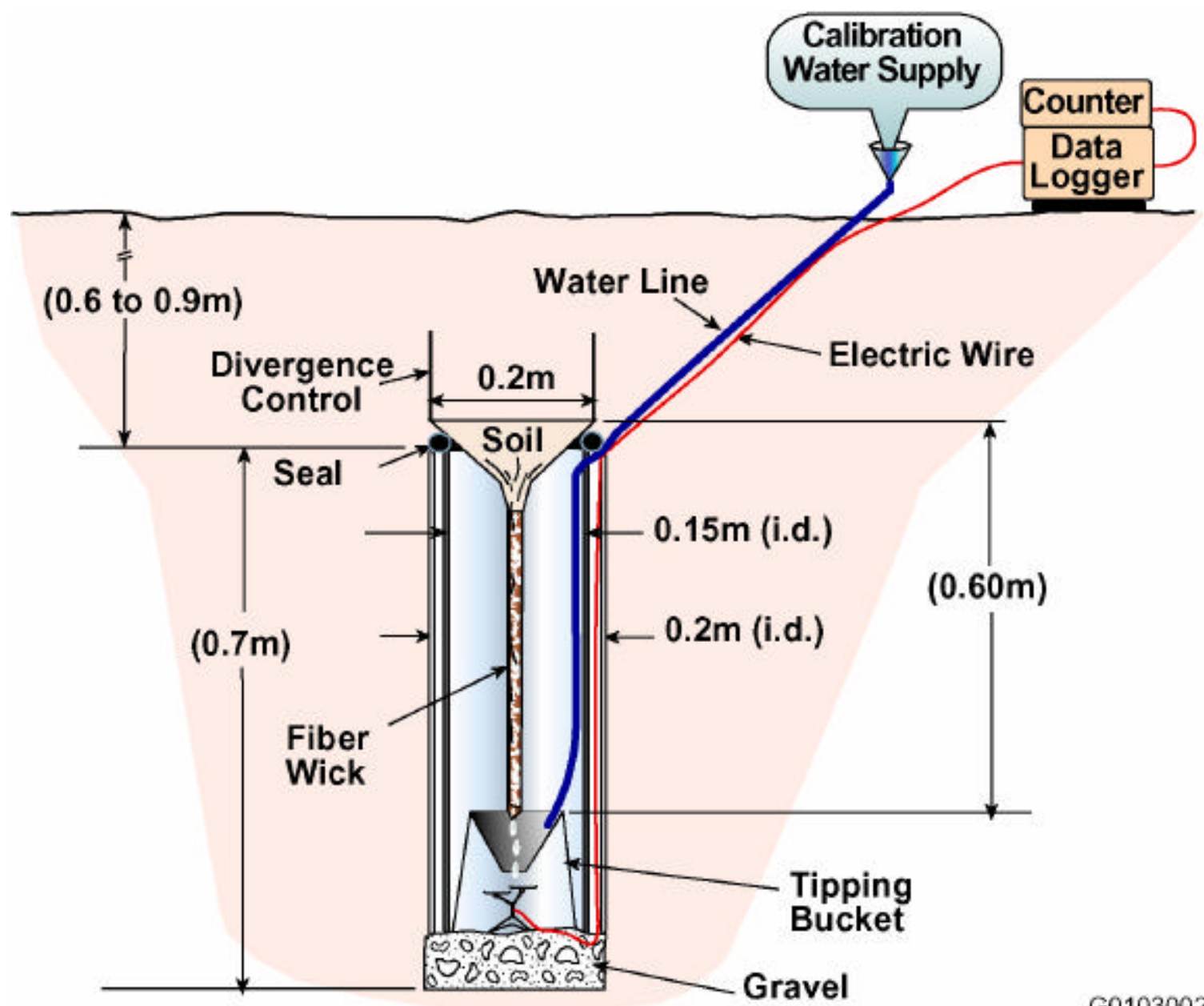

G01030028.1

Figure 2.9. Schematic View of the PNNL WFM. The divergence control for all drainage tests was at least $60 \mathrm{~cm}$. For bare soil conditions, including Tank Farms, the divergence control was brought to the surface or within a few $\mathrm{cm}$ of the surface to minimize any lateral flow.

\subsection{Temperature Sensors}

The temperature sensors, placed in the B Tank Farm, include both AD590MH solid-state precision temperature transducers (Analog Devices, Norwood, MA 02062-9106) and thermocouples (copperconstantan). The factory calibration curves for the AD590MHs are used to convert the sensor outputs to subsurface temperatures. The factory calibration indicates that the sensors have a precision of $\pm 0.5 \mathrm{~K}$ over the temperature range of -25 to $105^{\circ} \mathrm{C}$. The sensors have a current output of $1 \mathrm{microamp} / \mathrm{K}$, and the current was estimated by the voltage drop across a $250 \pm 0.1 \%$ ohm resistor. Thus, the calibration equation for each sensor is $\mathrm{T}\left({ }^{\circ} \mathrm{C}\right)=4 * \mathrm{mV}-273$, where the $\mathrm{mV}$ in the voltage drop across the 250-ohm resistor is in millivolts. The HDU sensor has a thermocouple (Figure 2.2) so that there is a redundancy in temperature measurements for the B Tank Farm. Only thermocouples were used for temperature sensing for the TX Tank Farm. 


\subsection{Data Logger}

A Campbell Scientific CR 23X (CSI, Logan, Utah) is used to collect and store data from the ATs, heatdissipation sensors, temperature sensors (downhole and at instrument panel), and water-fluxmeter for the water-balance monitoring sites in the 300N Area and the Tank Farms. Data are collected on a regular daily interval and stored in the internal memory. The data logger is powered by a battery that is recharged by a solar panel so that it is not affected by power outages. The data can be accessed using a cellular phone for remote data collection. In the case of the $300-\mathrm{N}$ site, the data are hooked to a phone line. The entire package has been designed to allow continuous long-term and unattended data collection.

\subsection{Installation Method}

Installation methods differed at each site and were dependent on instrumentation used and specific site conditions encountered and thus will be described in turn for each location.

\subsubsection{0-N Test Site}

The 300-N site is located just north of Richland, Washington, at DOE's Hanford Site, just south of the Fast Flux Test Facility (FFTF), and within $300 \mathrm{~m}$ of the 300 Area Burial Grounds (618-10). A detailed description of the site is provided by Gee and Jones (1985), Gee et al. (1992), and Sisson et al. (2002). A series of lysimeters was constructed at this site in 1978. The lysimeters were designed for water-balance studies and simulate waste-burialgrounds with bare, coarse-grained surfaces. The lysimeters can accommodate a variety of instruments for performance testing. Two of the lysimeters were selected to test AT performance, specifically testing for ease of installation, operational stability, durability, and longevity. In August of 1999, six ATs, similar to those shown in Figure 2.1, were installed using a commercial drill-rig (Mobile B6, Mobile Drilling Co., Indianapolis, IN). An 8.25-in.-diameter hollow-stem auger was used to drill into sandy fill material of the south lysimeter (Figure 2.10). The hollow-stem auger held open the hole, preventing collapse, while tensiometers were placed at selected depths. Cuttings from the auger flights were used to backfill around the tensiometers, the auger sections withdrawn, and the tensiometers left to equilibrate with backfill and the surrounding sediments. In addition, two DCT-type tensiometers (Figure 2.2 and Figure 2.3) were installed in February and March of 2000, within and adjacent to the North Lysimeter at the 300-N site (Figure 2.10). Both of the DCT-type tensiometers were hydraulically pushed into the subsurface to a depth of $7 \mathrm{~m}(23 \mathrm{ft})$ using CPT. Details of the DCT tensiometer placement can be found in Sisson et al. (2002). In addition to tensiometers, three CS-615 water-content sensors were placed vertically in the top meter of the south lysimeter to monitor water content and water-storage changes (Sisson et al. 2002). A Pronamic rain gage, similar to those used in our water fluxmeters, was installed at the drainage outlet in the bottom of the lysimeter (Figure 2.10) in August 2000. The rain gage was connected electronically to a data logger to measure drainage on a continuous basis. In April 2002, two water fluxmeters were also installed in the south lysimeter and connected to the data logger. 


\section{Plan View}

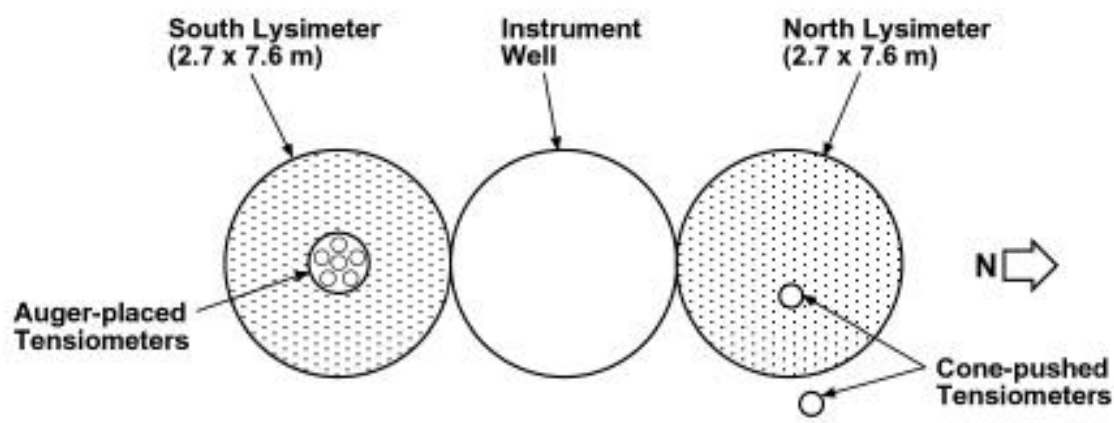

Elevation View

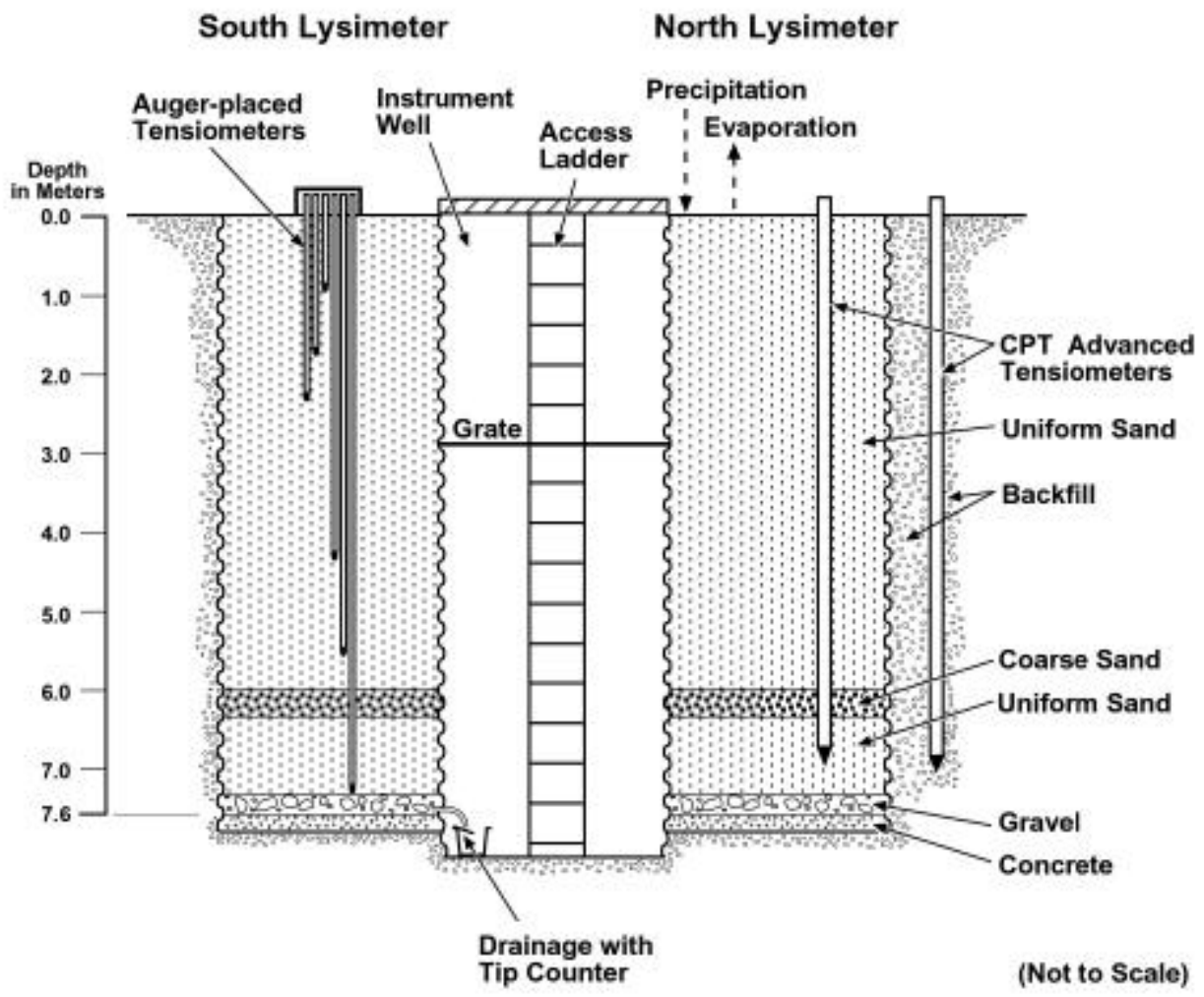

Figure 2.10. Schematic of the 300-N Lysimeter Site Showing the North and South Lysimeter and Locations of Auger-Placed and CPT-Placed Tensiometers. Not shown are three water-content sensors, located in the top meter of the south lysimeter.

\subsubsection{B Tank Farm-Borehole C3360}

The borehole (C3360) (also designated as 299-E33-46) is located adjacent to Tank B-110 in the B Tank Farm within the 200 E Area of the Hanford Site. Figure 2.11 shows the B Tank Farm during the drilling of borehole C3360 in July 2001. 


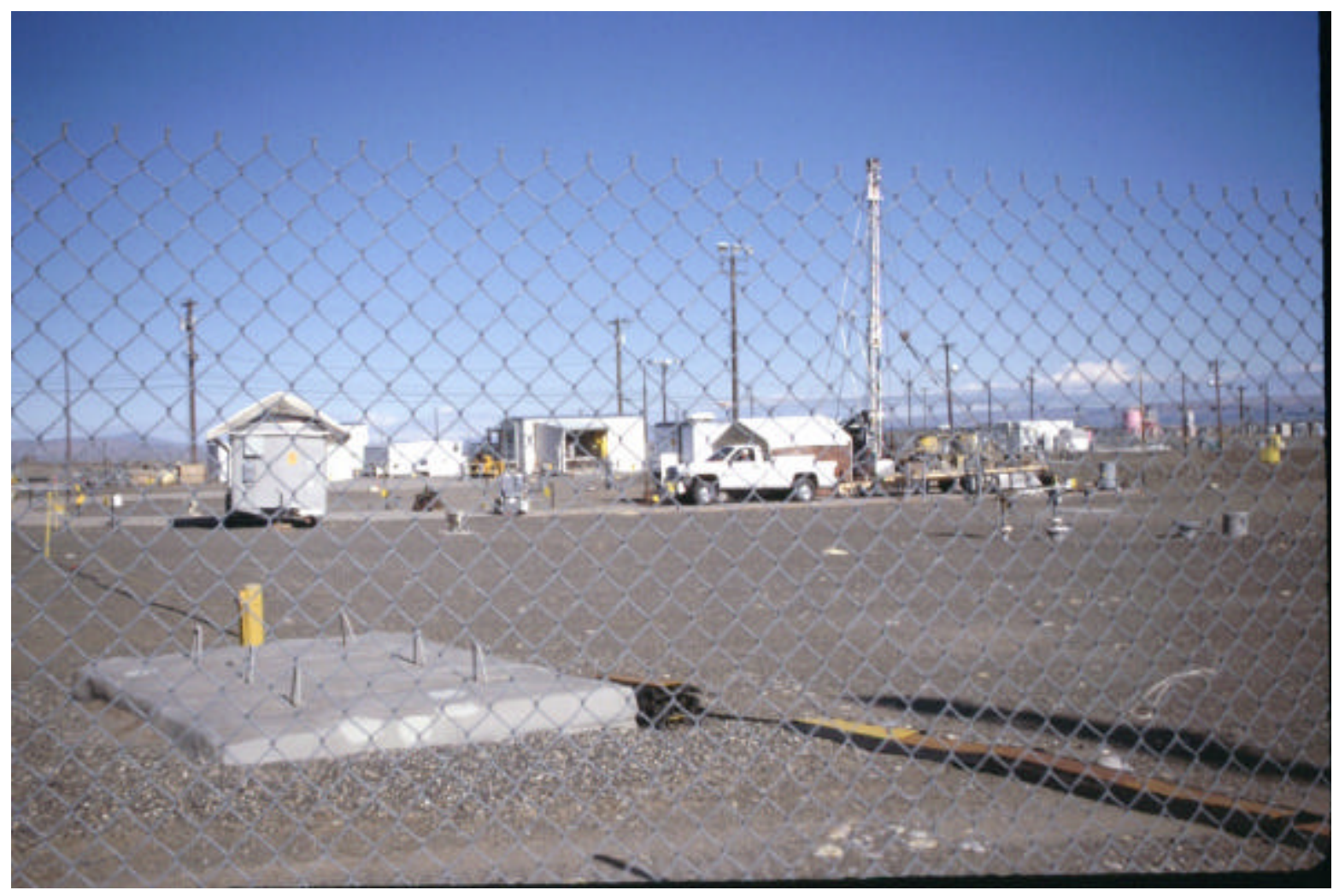

Figure 2.11. View of B Tank Farm in the 200 E Area, Hanford Site, Washington, in July 2001 During the Drilling of Borehole C3360. Borehole C3360 is located adjacent to Tank B-110.

Borehole C3360 consisted of a $0.26-\mathrm{m}(0.85-\mathrm{ft})$ diameter hole that was steel cased with bentonite at the bottom. The casing was pulled a few $\mathrm{ft}$, and a $0.3-\mathrm{m}$ (1-ft) layer of sand was placed at the bottom to reduce the chance of the VZMS assembly coming into contact with the bentonite. The VZMS assembly, consisting of sets of sensors (as shown in Table 3.1) was lowered to the bottom of the hole (Figure 2.12). The water-content sensor was set against the borehole wall using its attached lever arm (Figure 2.12). The process of seating the sensor against the wall was monitored with the aid of a down-hole video system. Once the VZMS was placed satisfactorily, the assembly was grouted in place with a silica-flour slurry (SCS-90, U. S. Silica, Ottawa, IL). Silica flour slurry has been used by INEEL in similar installations of VZMS systems in Idaho, Savannah River, and Oak Ridge to assure that hydraulic contact is made between the sensors and the formation. The backfill was allowed to settle a few minutes, and a sand plug was added on top of the grout. If the silica-flour backfill had not drained to a firm condition, it was found that the sand penetrated into the backfill until a firm hole resulted. Once a firm bottom was obtained, as evidenced by the feel of the tag line used to monitor backfill placement, the hole was backfilled with bentonite as casing was being pulled to the depth of the next installation. At the level of the next VZMS assembly, a 0.3-m (1-ft) layer of sand was added, and the sensor assembly was inserted. This methodology was repeated up to the 6.2-m (20.4-ft) bgs depth, where backfill was switched to sand and tank-farm fill materials. A PNNL water fluxmeter was installed, with the bottom of the fluxmeter at 
1.8- $\mathrm{m}$ bgs and the top extending to ground surface Additional detail related to installation and geologic features observed during drilling of the borehole is provided in Appendix A.

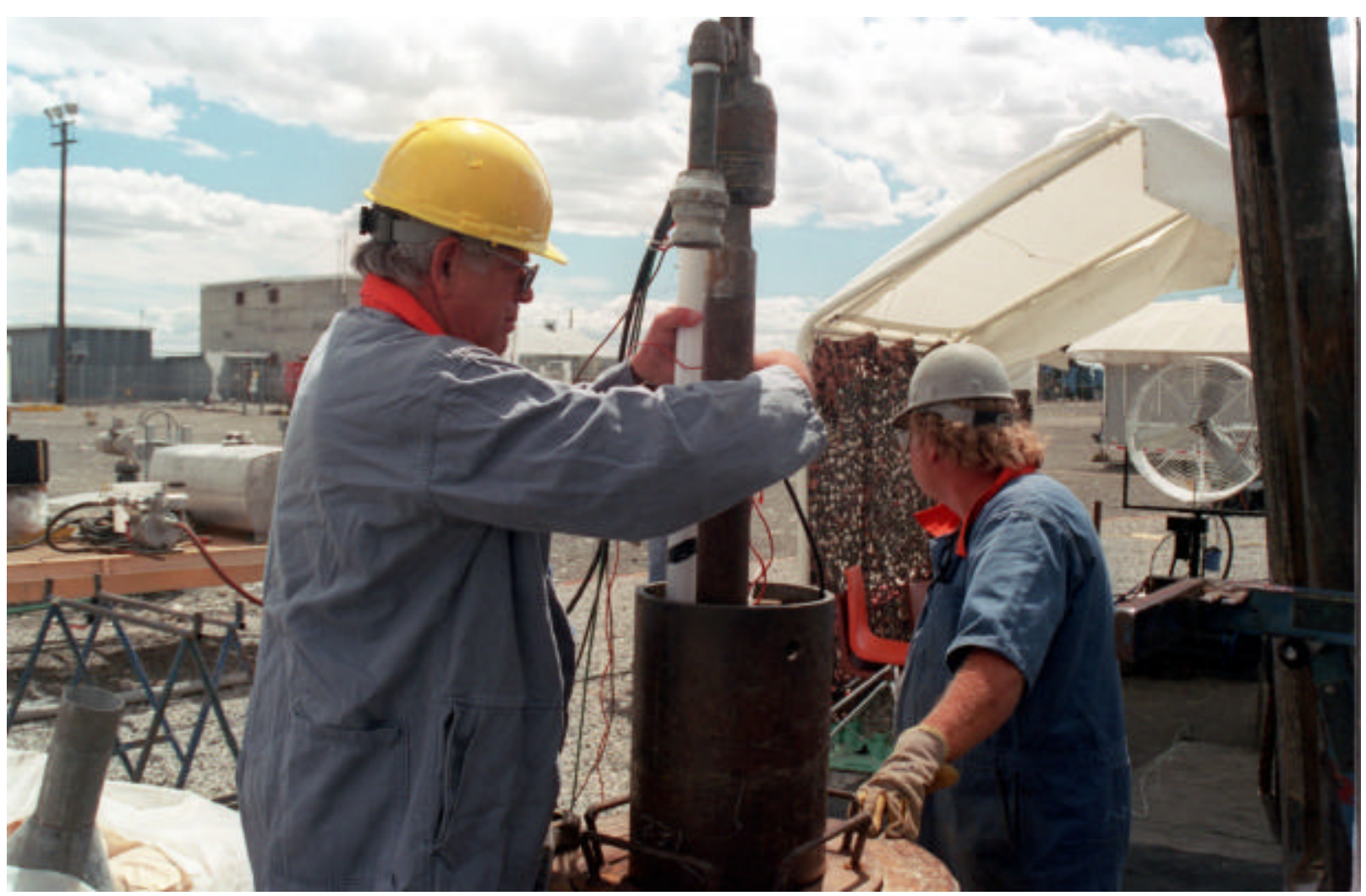

Figure 2.12. Installation of VZMS System in Borehole C3360 at B Tank Farm in 200 E Area Hanford Site, July, 2001

Figure 2.13 shows the well completion and top of the water fluxmeter. The instrumentation was connected to a data-acquisition system consisting of a CR23X data logger (CSI, Logan, Utah), cellular phone, modem, power supply, and solar panel. A Rain-O-Matic rain gage (Pronamic Co. Ltd. Sikeborg, Denmark) was installed at the site to record precipitation. Figure 2.14 shows the data-acquisition system adjacent to the completed C3360 borehole in the B Tank Farm. Data from the system are recorded hourly and sent daily to the PNNL laboratory where it is downloaded to a secure server. The data are stored, and backup files are created. Graphical displays are generated in a systematic manner providing plots of soil water pressures, temperatures, and water balance, e.g., precipitation and drainage. These plots are generated in three sets displaying detail for all data recorded from 1) start of monitoring, 2) past year, and 3) past 90 days. Because of potentially sensitive information, the web site is a secure site and accessed only by a protected password. 


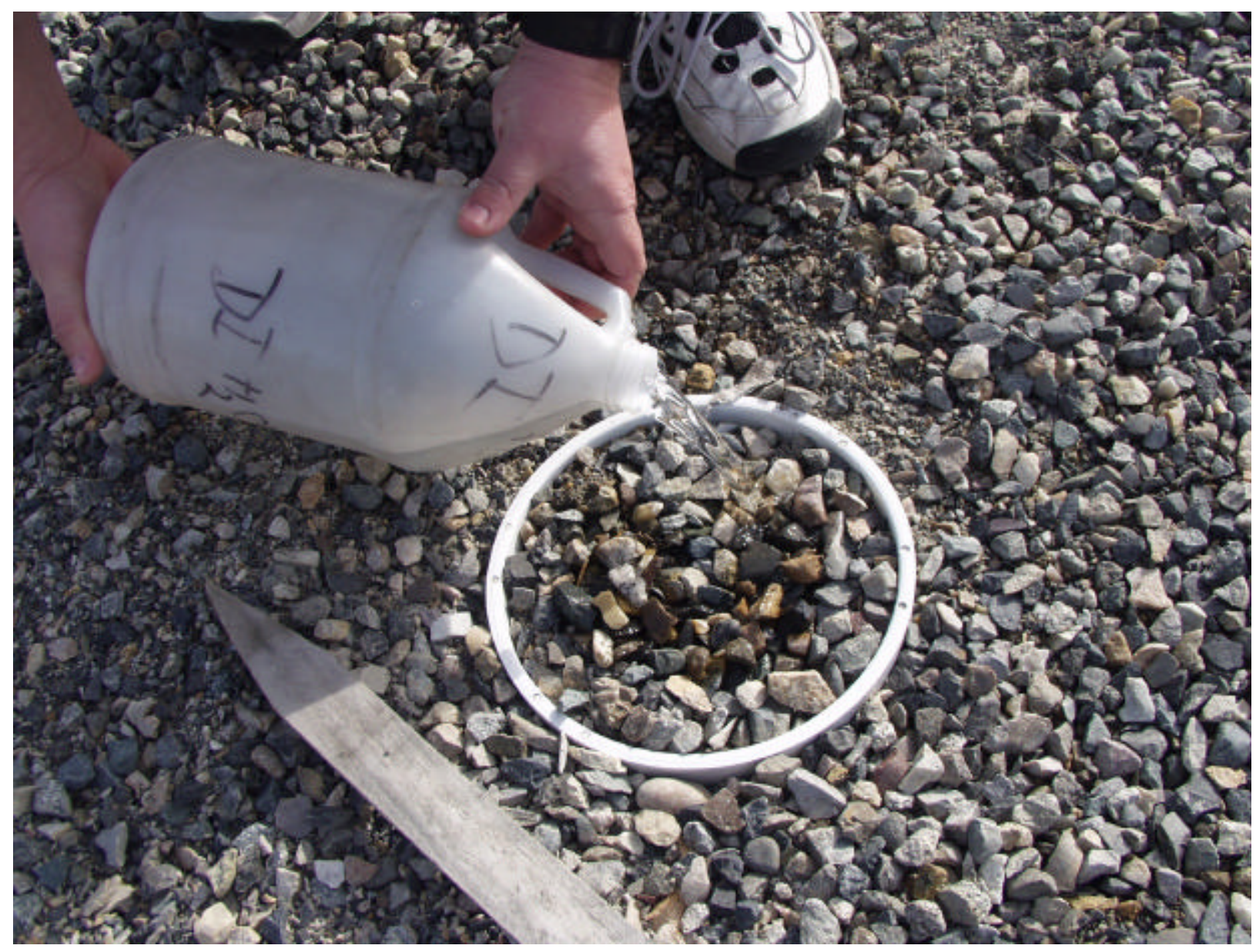

Figure 2.13. Completion of Well C3369 Showing Coarse-Gravel Surface and Top of the Water Fluxmeter. The surface of the water fluxmeter was prewetted before drainage monitoring. 


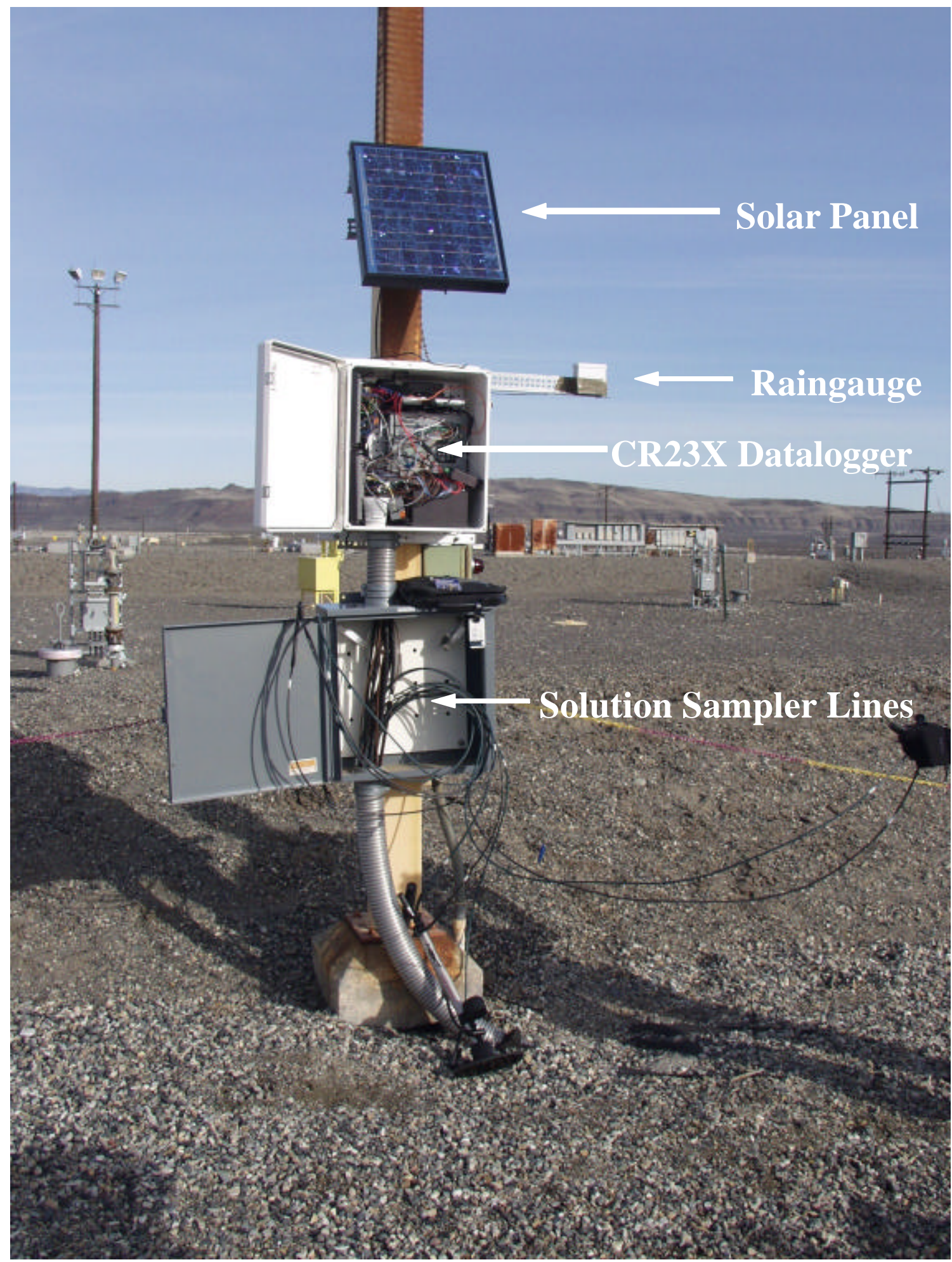

Figure 2.14. Data Aquisition System, Including Solution Sensor Lines, Data Logger, Solar Panel, and Raingage, Located Adjacent to Completed Borehole C3360 next to Tank B-110 in B Tank Farm, 200 E Area 


\subsubsection{TX Tank Farm- Borehole C3830 and Water Fluxmeter Placements}

Borehole C3830 is located in the TX Tank Farm in the $200 \mathrm{~W}$ Area of the Hanford Site. The borehole is located near Tank TX 105,to the immediate northeast of Tank TX 101. The well diameter was 7.5 inches and the borehole drilled to 116.8 feet bgs. A procedure similar to that used at the B-110 borehole (C3360) was followed during the completion of this borehole. Casing was driven to depth of refusal (116.8 feet) The formation consisted of interbedded sands and gravels to a depth of 109 feet. Tight caliche (cemented) material was encountered below this depth. As casing was pulled, bentonite granules were poured into the borehole to a depth of $101.2 \mathrm{ft}$. bgs. A 30-mesh sand was used to fill the borehole to a depth of $96.2 \mathrm{ft}$. In this zone the tensiometer and temperature sensor was placed. The process was repeated such that three additional tensiometers were placed at depths of 55 to 50 feet, 11 to 7.5 feet and 6.9 to 2.9 feet bgs, all enclosed in a sand pack interval between bentonite fill. Natural fill was added to from 2.2 feet to the surface to complete the borehole. Directly south of borehole C3830 and just out side the TX tank-farm perimeter fence two additional boreholes C4089 and C4090 were drilled using a 15 inch aguer to a depth of 6 feet. Geophyiscal monitoring using ground-penetrating radar was used to document acceptable location for the borehole placaement. A water fluxmeter was placed in each of the two boreholes at the tank farm perimeter. The water fluxmeters were with diversion control extensions (see figure 2.9) were within $15 \mathrm{~cm}$ of the surface. The two shallow boreholes for the waterfluxmeters were completed to the surface using natural fill (gravel with sand).

Figure 2.15 shows a view of the TX Tank Farm in September 2002, during installation of borehole C3830. 


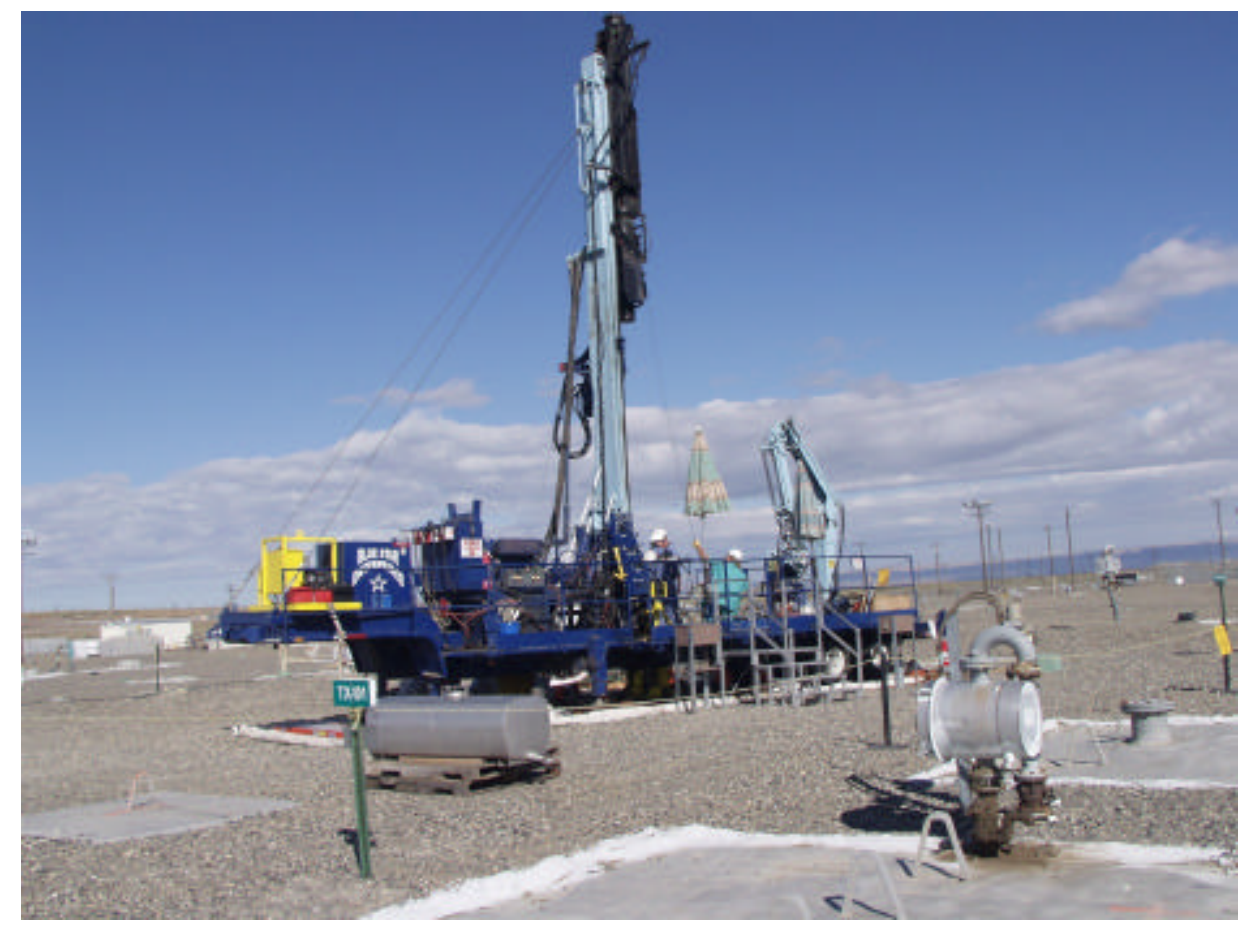

Figure 2.15. View of the TX Tank Farm in 200 W Area, Hanford Site, Washington, During Installation of Borehole C3830 in September 2002. Borehole C3820 is located near Tank TX-105.

Figure 2.16 shows a schematic of the sensor placement in borehole C3830, located near Tank TX-105 and the water flux meter installation at the periphery of the tank farm south of TX-101. 


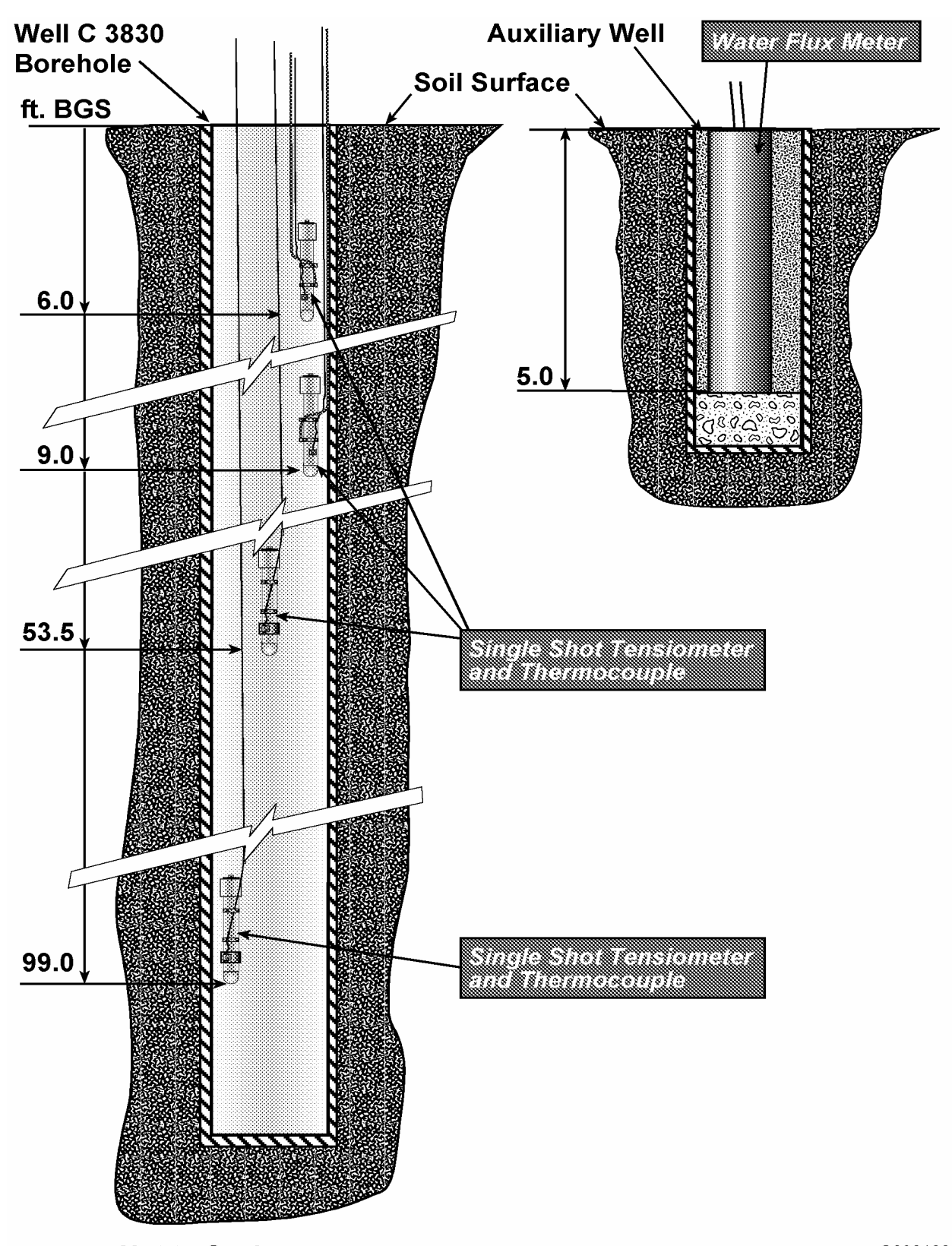

Not to Scale

G0301005

Figure 2.16. Schematic of Sensor Placement in Borehole C3830, Located near Tank TX-105 and the Water Flux Meter Installation Located at the Periphery of the Tank Farm South of TX-101 
Figure 2.17 shows the placement of an AT in borehole C3830 at TX Tank Farm, September 2002.

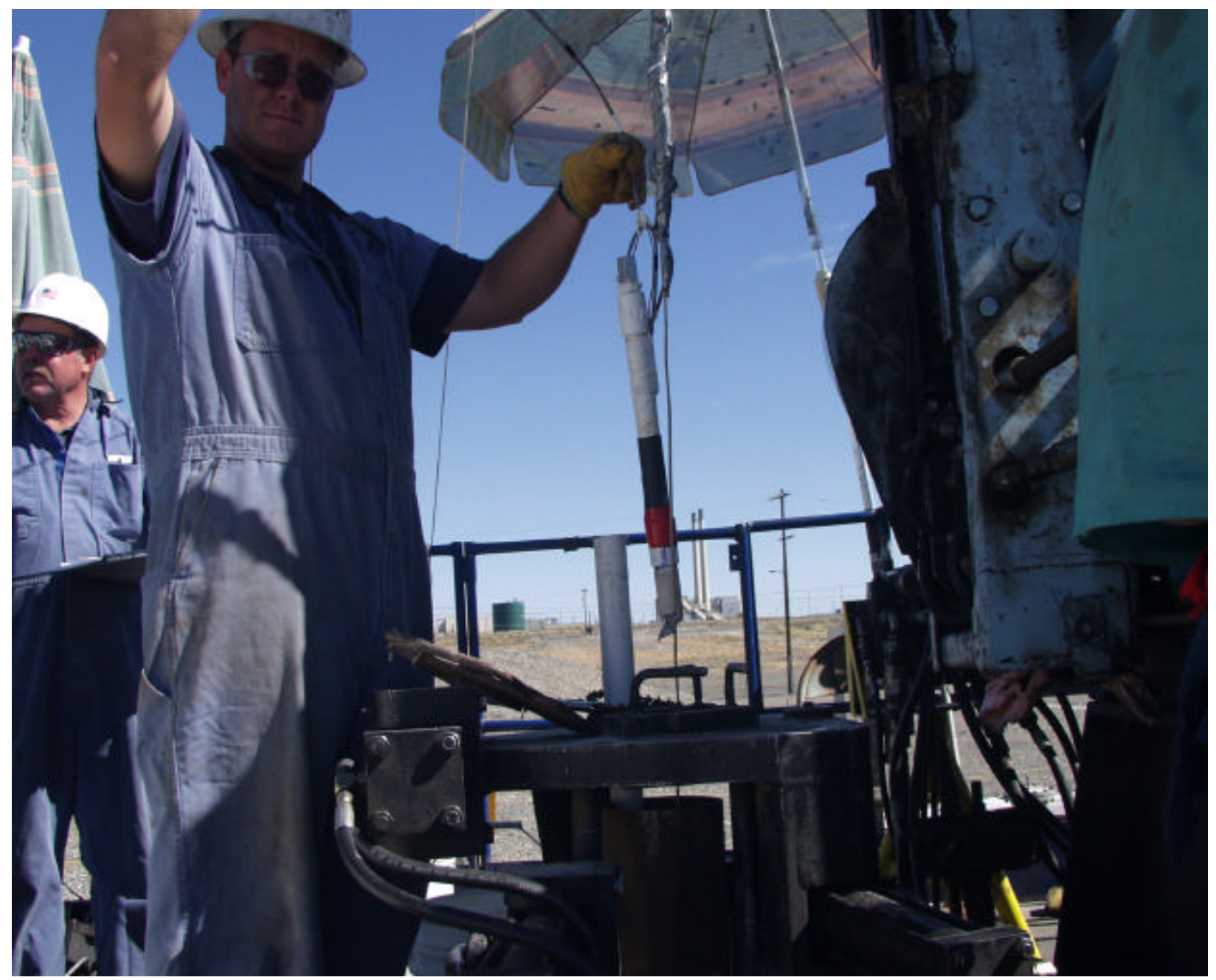

Figure 2.17. Placement of AT in Borehole C3830 at TX Tank Farm, September, 2002 
Figure 2.18 shows the placement of sand slurry in borehole C3830 in TX Tank Farm, September 2002.

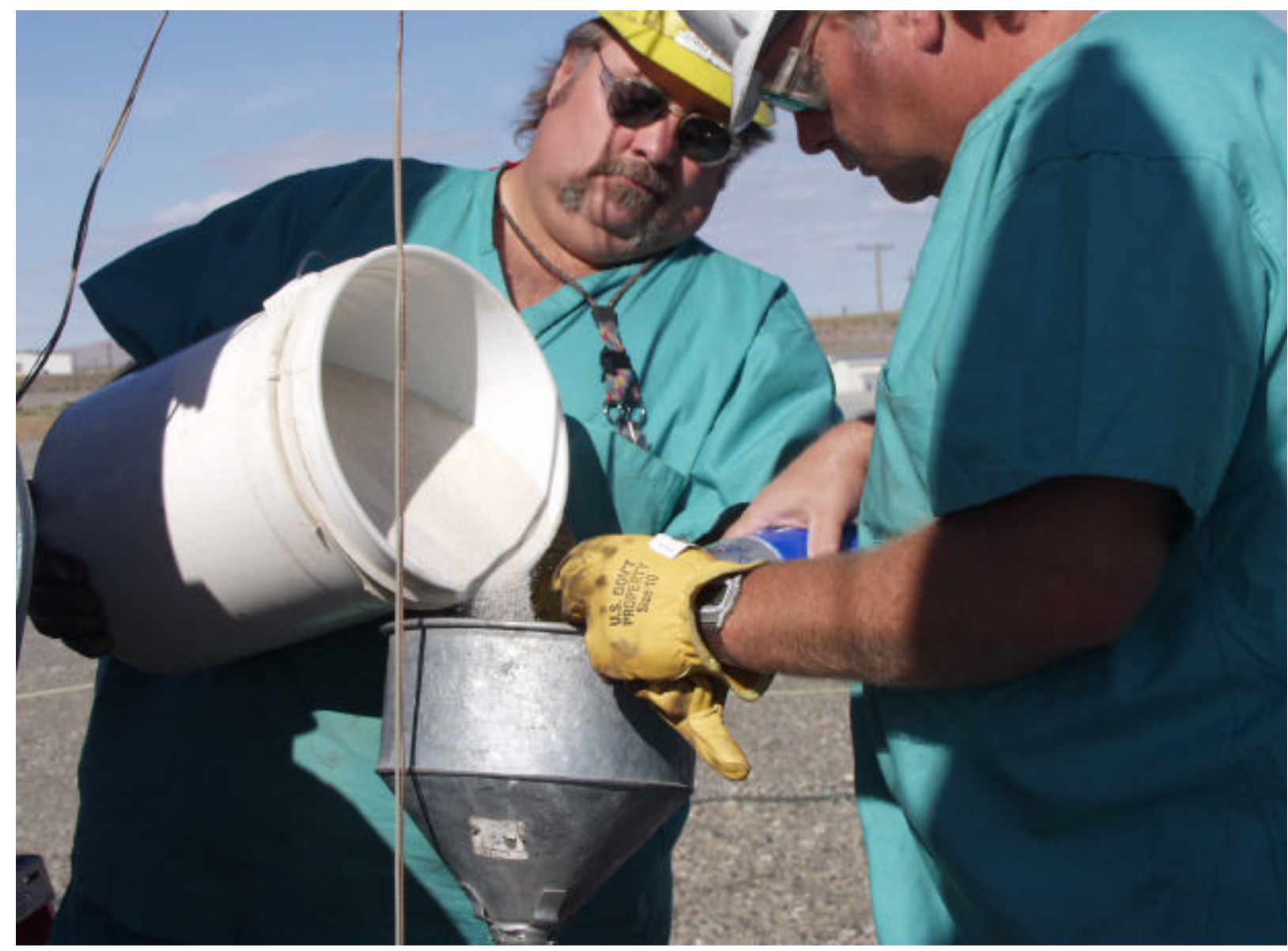

Figure 2.18. Placement of Sand Slurry in Borehole C3830 in TX Tank Farm, September 2002 


\subsection{Results and Discussion}

\subsection{0-N Data}

Data from the 300-N test area provide information about the performance of tensiometers and hydrologic monitoring in the vadose zone under simulated waste-site conditions at Hanford. Current data from the 300-N tests can be found on the PNNL web site, http://vadose.pnl.gov. As indicated earlier, all data from the 300-N Site are automatically retrieved electronically on a daily basis and stored on a PNL server. Plots of sensor response with time are generated for periods ranging from 90 days through the duration of the test (over 3 years). Soil water pressures are documented for the auger-placed ATs and the direct-pushed DCTs. In addition, precipitation, drainage, water storage, and total hydraulic-head profiles are displayed on the web site. Figure 3.1 illustrates the time course of the tensiometer (soil water pressure) data since September 1999 (over 3 years). The data show that tensiometers in the top $2 \mathrm{~m}$ $(6.6 \mathrm{ft})$ are responsive to winter precipitation and subsequent evaporation events, as indicated by changes in pressure for the top three tensiometers. The response dampens quickly, so that below $3 \mathrm{~m}(9.8 \mathrm{ft})$, there is little response to precipitation or evaporation, and the deeper pressure profiles remain steady with time. Except for the tensiometer at the 0.9-m (29.5-ft) depth, none of the tensiometers required refilling or recalibration during the past 3 years. While there are a few missing data points and some noise for short periods of time, the data are surprisingly stable.

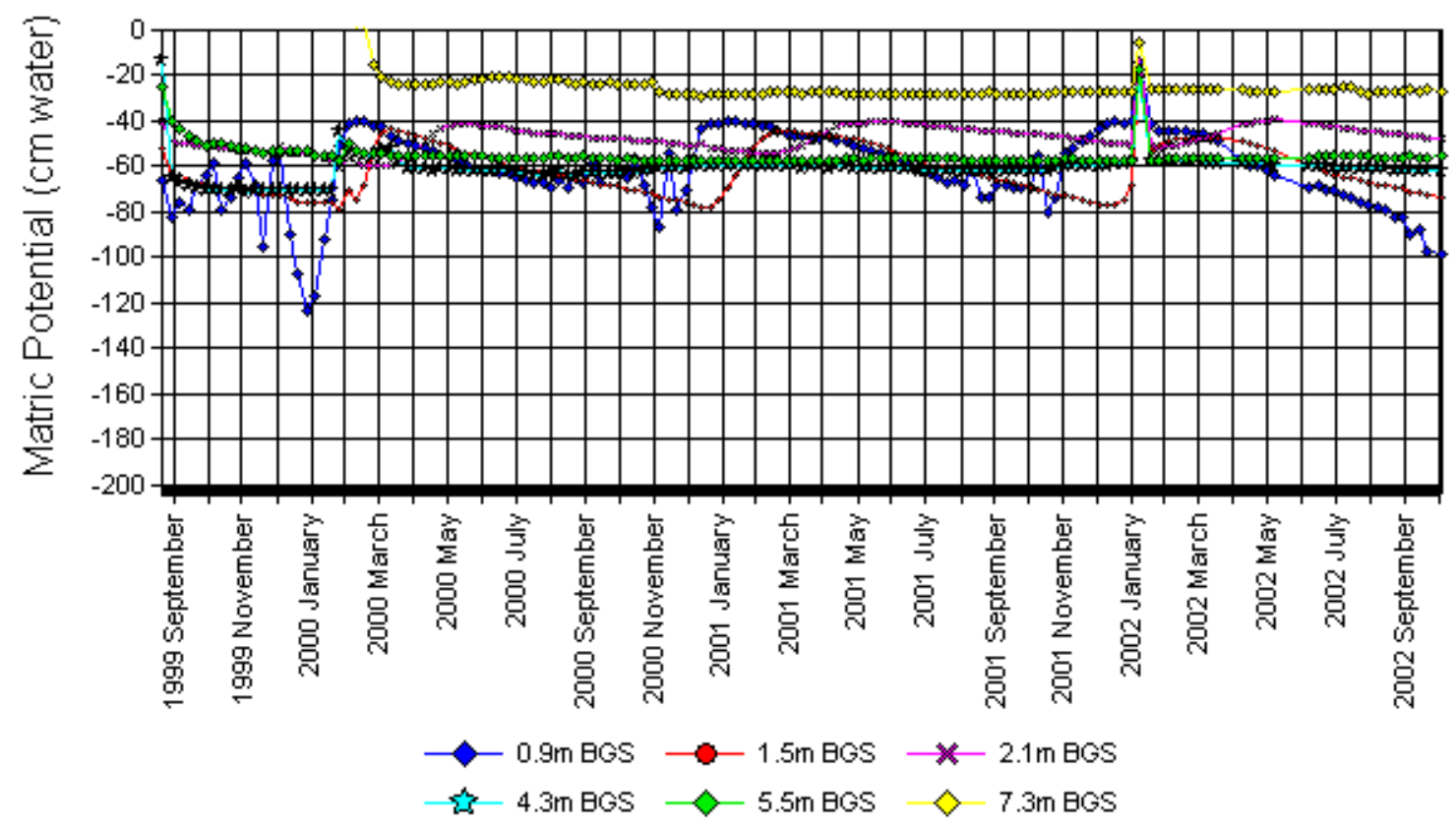

Figure 3.1. Time Course of Soil Water Pressure as Measured with Auger-Placed ATs at the 300-N Lysimeter Site 
The data show that for bare, coarse sand under Hanford Site conditions, soil water pressures below a 2-m (6.6-ft) depth range from a -20 to $-80 \mathrm{~cm}$ (-7.9 to $-31.5 \mathrm{in}$.) head, values indicative of a draining soil profile. At depth, the hydraulically pushed DCTs show very similar soil water pressure values as the auger-placed ATs (Figure 3.1 and Figure 3.2). The two DCT units tracked each other remarkably well and have maintained a nearly steady $-40 \mathrm{~cm}(-15.7 \mathrm{in}$.) head for the duration of the testing (Figure 3.2). It should be noted that the DCTs equilibrated rapidly with the sediments and were stable within a day of placement (both inside and outside of the lysimeter). This is in contrast to the auger-placed ATs, which took several weeks to equilibrate. The difference in initial response of the ATs is not surprising because the degree of soil disturbance is much greater with auger placement, so the AT units would be expected to take longer to equilibrate than direct-pushed DCT units. Totathead profiles are shown in Figure 3.3 for the auger-placed tensiometers. The results confirm that unit gradient conditions exist at this site. This is expected since drainage has been measured at this site for over 20 years (Gee and Jones 1985; Gee et al. 1992; Sisson et al. 2002).

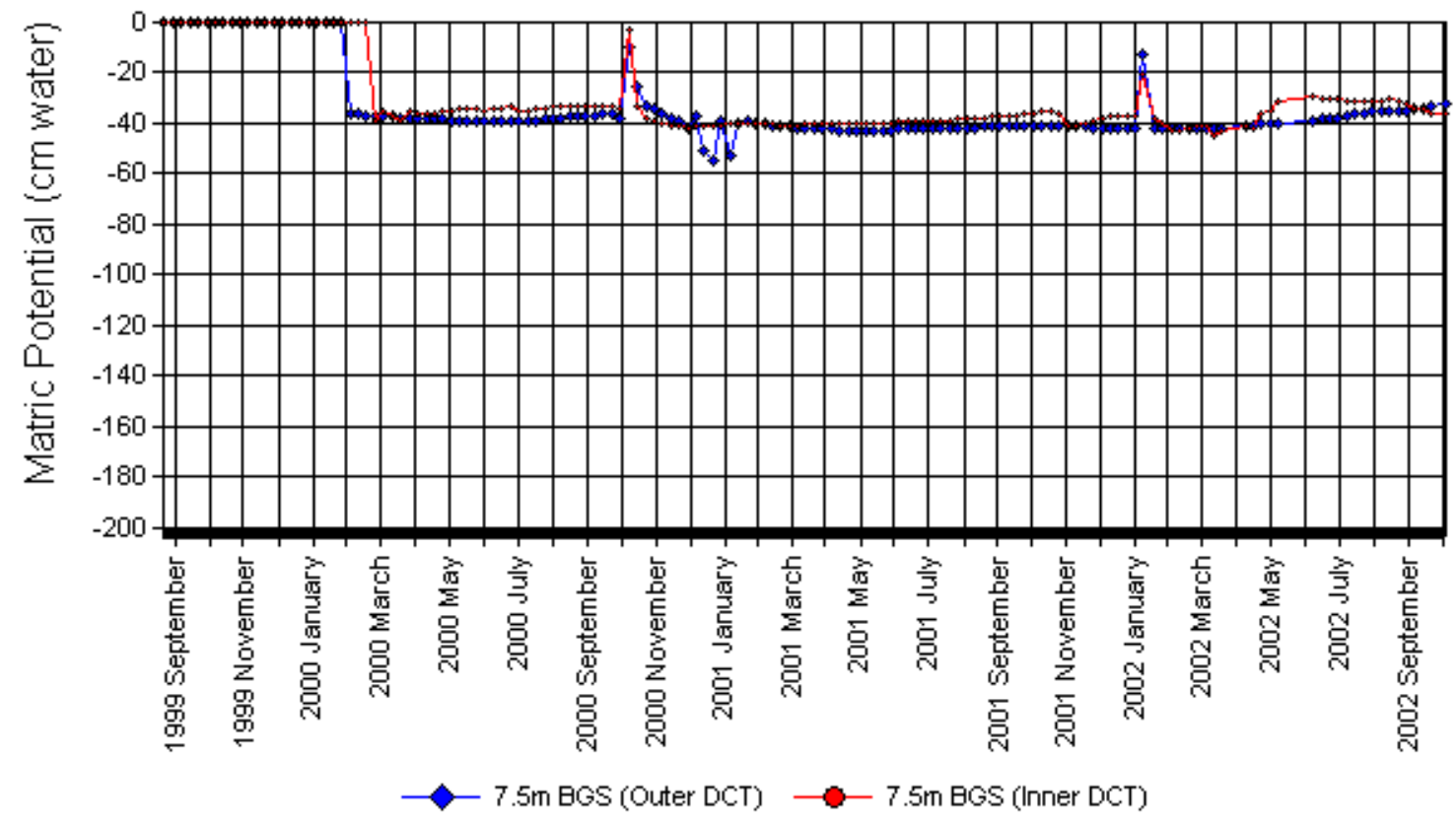

\section{Figure 3.2. Time Course of Soil Water Pressure as Measured with Drive-Cone Placed Tensiometers (DCTs) at the 300-N Lysimeter Site}

The water balance was monitored at the $300 \mathrm{~N}$ site over the course of the test. Precipitation and drainage records have been maintained at this site for over 20 years. Water storage was collected over the past 3 years (using CS-615 water content reflectometers as shown in Figure 2.6). Figure 3.4 shows the water balance at the south lysimeter. Note that evaporation is computed as a residual in the waterbalance equation as:

$$
\mathrm{E}=\mathrm{P}-? \mathrm{~S}-\mathrm{D}
$$


where: $\mathrm{E}$ is evaporation; $\mathrm{P}$ is precipitation; ?S is storage change, and $\mathrm{D}$ is drainage.

Initial drainage was higher than expected because the water table in the lysimeter was lowered in order to connect the automatic drainage collection system. In addition, the manual drainage system had not been monitored for more than 2 years (before September 1999).

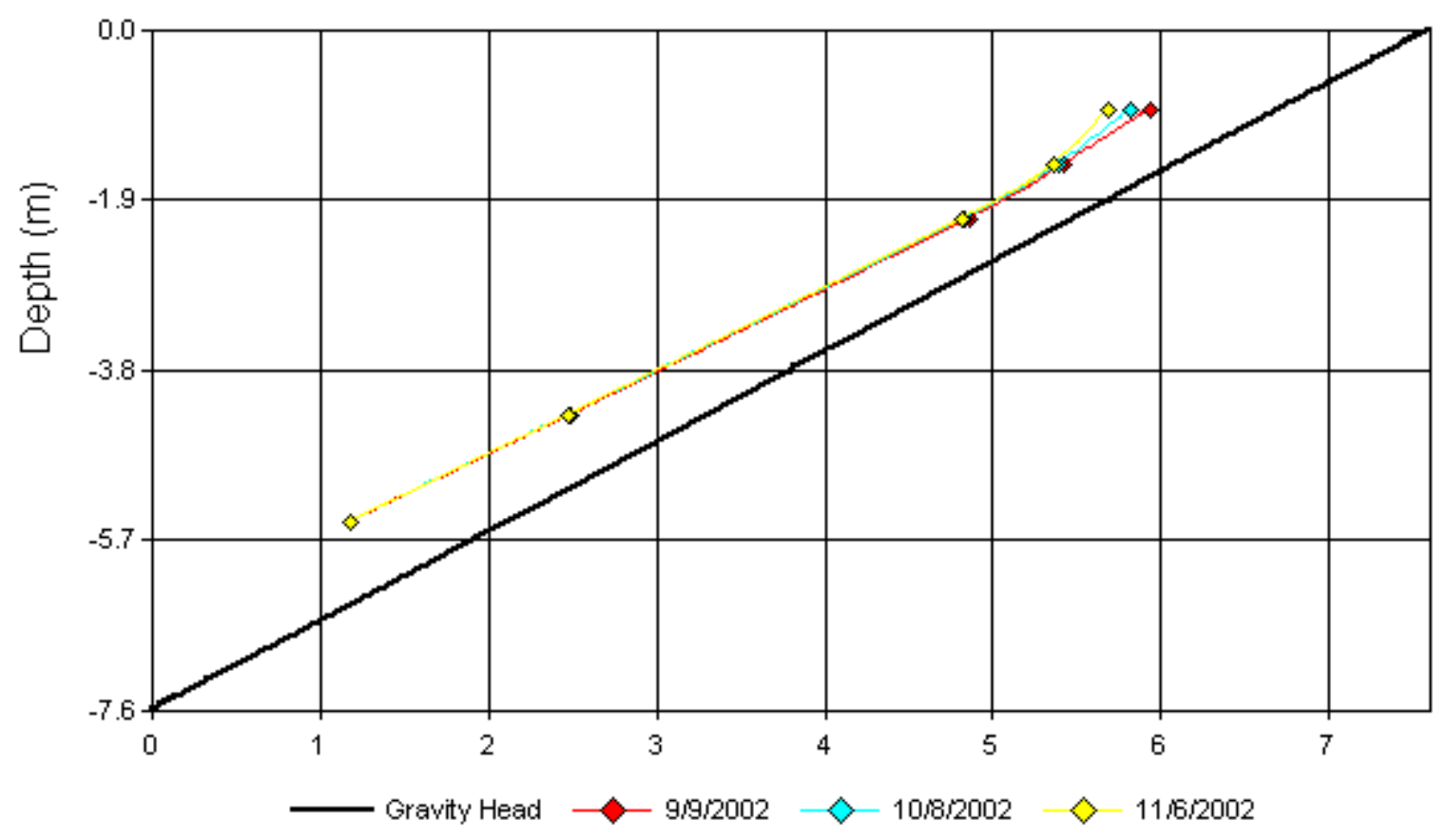

Figure 3.3. Total Head vs. Depth for 300 North 


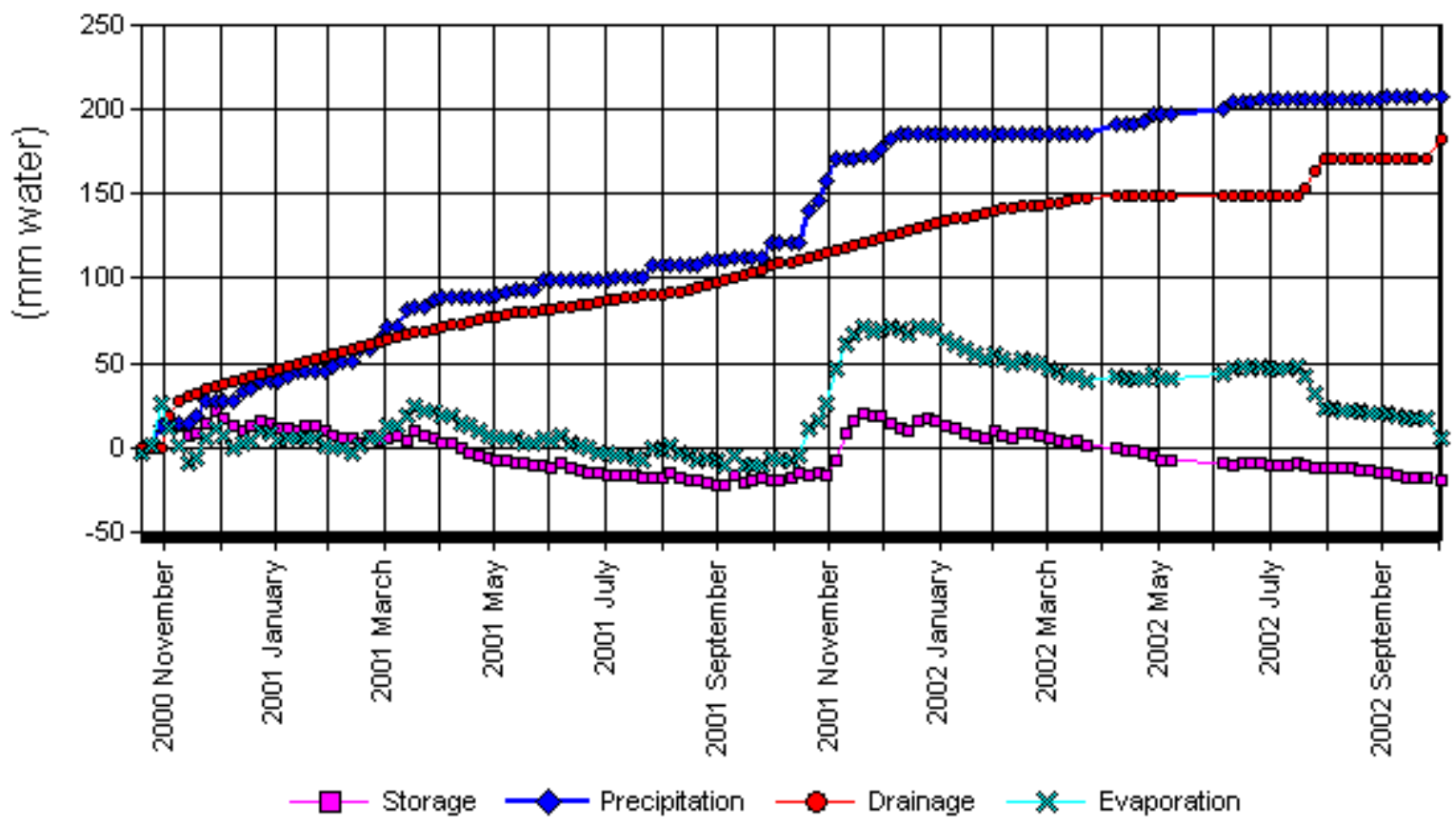

Figure 3.4. Water Balance for 300 North

Because the North Lysimeter is deep (7.6 $\mathrm{m}[25 \mathrm{ft}])$, there is a lag between water applied on the surface in winter and water drainage from the lysimeter (assuming a pulse response). Typically, the lag response is about 6 months, from the time that transient water pulses are incident on the surface until water exits the lysimeter. The actual time for a particle of water to infiltrate and move through the sediments to the water table depends on the soil water content, the depth the lysimeter, and the incident flux rate. At an average rate of $55 \mathrm{~mm} / \mathrm{yr}$ ( $2 \mathrm{in} . / \mathrm{yr}$ ), water moving through sediment at $0.1 \mathrm{vol} / \mathrm{vol}$ water content over a depth of $7.5 \mathrm{~m}(24.6 \mathrm{ft})$ has a travel time of 13.6 years. This suggests that after nearly 24 years, nearly 1.8 pore volumes have leached through the lysimeter. More rapid flow would be expected in coarser sediments (e.g., gravels) and slower flow in finer sediments (e.g., silts and clays) at similar water contents and incident flux rates.

Another contribution of VZMS data is to assess the unsaturated hydraulic conductivity. At the 300-N site, there have been attempts to evaluate methods to measure unsaturated hydraulic conductivity. Gee and Ward (2002) have reported results from the 300-N site that indicate that laboratory methods (using textural estimates and steady state column tests) can significantly overpredict actual unsaturated hydraulic conductivities for this coarse-grained sediment (i.e., 92\% sand, 6\% silt, 2\% clay). Gee and Ward (2002) report several comparisons of the unsaturated hydraulic conductivity as a function of soil water pressure (or tension). Based on actual drainage measurements, the unsaturated hydraulic-conductivity at field water content and pressure is overestimated by more than two orders of magnitude, using textural data and data from steady-state laboratory columns. In comparison, a field-drainage test, employing neutron probe and tensiometer to measure the instantaneous profile (Rockhold et al. 1988), yielded results that are virtually identical with the deep-drainage measurements and estimates of Sisson et al (2002). 
These observations suggest that field measurements of drainage are more reliable in predicting the unsaturated-conductivity function than pedotransfer functions (e.g., textures or similar characteristics) for at least some Hanford sediments. Direct measurement of drainage has been a desirable objective for Hanford site hydrologic characterization of the vadose zone. With the development and deployment of water flux meters, this objective can at least, in part, be realized. Over 50 deployments of water-flux meters have occurred in the past 2 years. An example of such deployments has been reported by Gee et al. (2002b). It is anticipated that in key areas of the site, flux measurements made over a period of a few years can lead to better characterization of the hydraulic properties of some of the key sediments that control the transport in the Hanford vadose zone.

\subsection{B Tank Farm}

The sensor locations at the borehole C3360, near Tank B-110, are listed in Table 3.1. The wellcompletion report is listed in Appendix A, where a complete listing of backfill materials, their precise placement, and depths of sensor assemblies is provided.

Data from Well C3360 are shown in Figure 3.5 through Figure 3.10. The soil water pressure data are shown on Figure 3.5. Since the pressure sensor used to monitor pressure in the tensiometers senses absolute pressure, the data exhibit considerable barometric noise. There is a barometric sensor on the data logger that will be used to correct the pressures for the barometric changes. However, it was determined that the barometric sensor is not correctly wired and is producing irrelevant results. In lieu of the actual barometric sensor, daily barometric averages of pressure as reported by the Hanford Meteorological Station (HMS), corrected for the altitude difference between the HMS and the 200E Area, were used.

Table 3.1. VZMS Sensor Placement in Borehole C3360 near Tank B110 in B Tank Farm

\begin{tabular}{||c|c|c|c|c|c|c||}
\hline \hline Depth (bgs) & WFM & AT & HDU & WC & Temp & SS \\
\hline 226 & & $\mathrm{X}$ & $\mathrm{X}$ & $\mathrm{X}$ & $\mathrm{X}$ & $\mathrm{X}$ \\
\hline 218 & & $\mathrm{X}$ & & $\mathrm{X}$ & $\mathrm{X}$ & $\mathrm{X}$ \\
\hline 82 & & $\mathrm{X}$ & $\mathrm{X}$ & $\mathrm{X}$ & $\mathrm{X}$ & $\mathrm{X}$ \\
\hline 53 & & $\mathrm{X}$ & & $\mathrm{X}$ & $\mathrm{X}$ & $\mathrm{X}$ \\
\hline 15 & & $\mathrm{X}$ & $\mathrm{X}$ & $\mathrm{X}$ & $\mathrm{X}$ & $\mathrm{X}$ \\
\hline 9 & & $\mathrm{X}$ & & $\mathrm{X}$ & $\mathrm{X}$ & \\
\hline 6 & $\mathrm{X}$ & $\mathrm{X}$ & $\mathrm{X}$ & $\mathrm{X}$ & $\mathrm{X}$ & \\
\hline 3 & & $\mathrm{X}$ & & $\mathrm{X}$ & $\mathrm{X}$ & \\
\hline
\end{tabular}

It was expected that the pressure data would show larger fluctuations over time as a result of the effect of adding fairly large volumes of water with the silica flour grout during the backfilling process. This indicates that the backfilling process used may have resulted in rapid equilibration in pressure between the backfill material and the surrounding sediments. We have used dry backfill material in the 
past, and it has typically resulted in equilibration times of several weeks. The tensiometer installed at the 1.8-m (15-ft) depth shows erratic behavior that is probably due to sensor malfunction, while the rest of the tensiometers give quite steady readings. Even so, all of the tensiometers give readings within the expected range. The data suggest that the backfill has equilibrated with the surrounding soil.

Figure 3.6 shows the total head at Well C3360. This is the sum of the soil water pressure head potential as measured by the tensiometers and the gravity head resulting from its height above the water table. The dashed line indicates the gravity head. The measured points are all slightly to the left of the gravity-head line, indicating that unit gradient conditions exist at the site.

Figure 3.7 shows water content changes at depth. The unexpectedly high readings from the sensors at 66.4- and 68.9-m (218- and 226-ft) depths may be due to high salinity or high clay content as discussed below. All of the water-content sensors show very little variation over time, indicating that conditions in the borehole are at equilibrium.

Figure 3.8 shows drainage as measured by the water fluxmeter. Initially, there was no drainage, likely because the sediments in the fluxmeter were dry, and a storage capacity had to be satisfied. In February 2002, a 2-L volume of water was added to the top of the fluxmeter. Drainage in response to that event is shown in Figure 3.8. Subsequent drainage also occurred through June 2002. It is expected that the drainage measurements from winter rains will be useful to document the recharge at this site during the next few years.

Figure 3.9 and Figure 3.10 show soil-temperature changes with depth over time. The data for the near surface show expected seasonal changes. At depth, the temperatures are constant and appear to be unaffected by heating from adjacent tanks, suggesting that little heat remains in the tank and the contaminant spill in the soil is not causing noticeable heating of the soil.

(a)

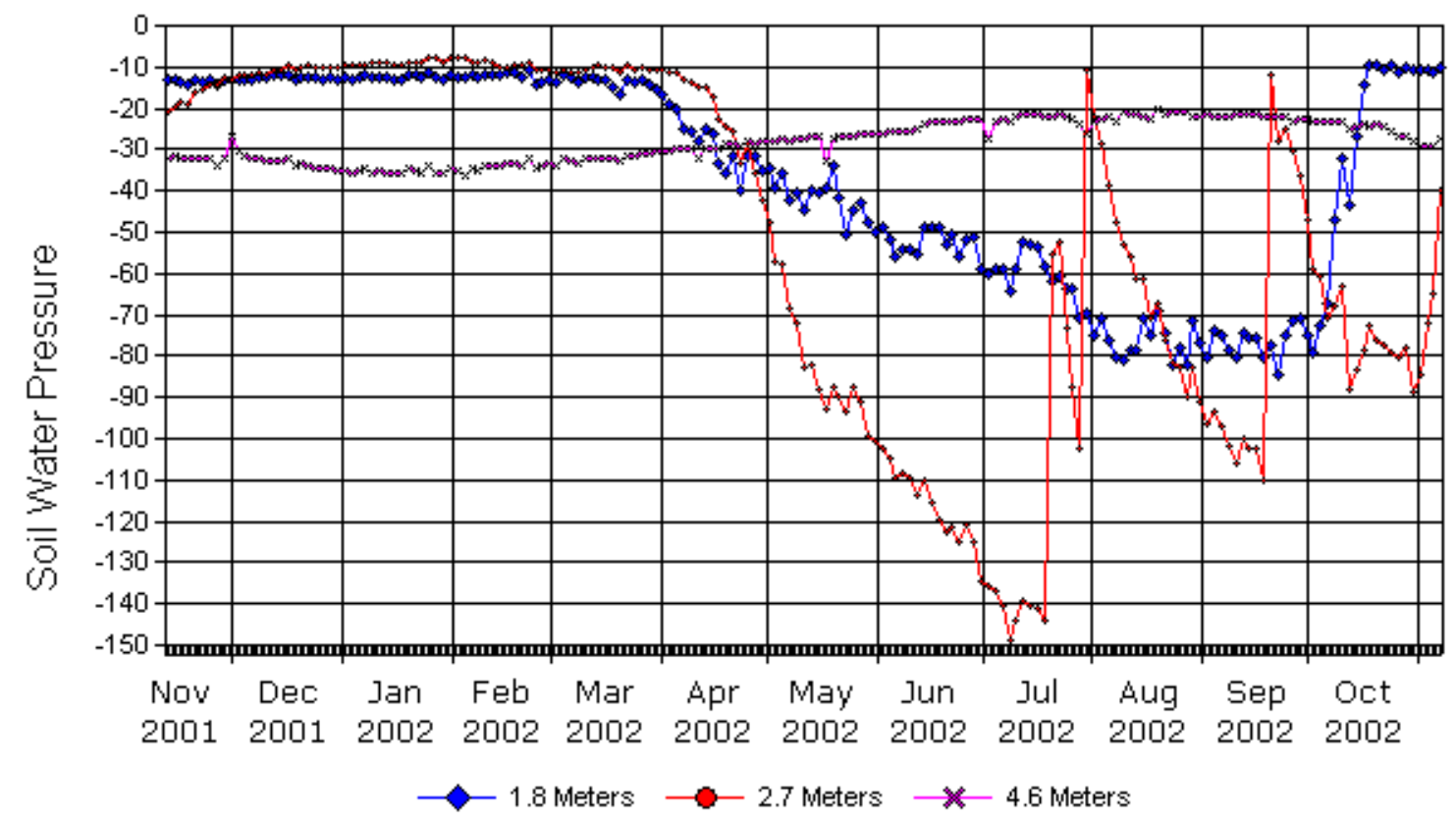


(b)

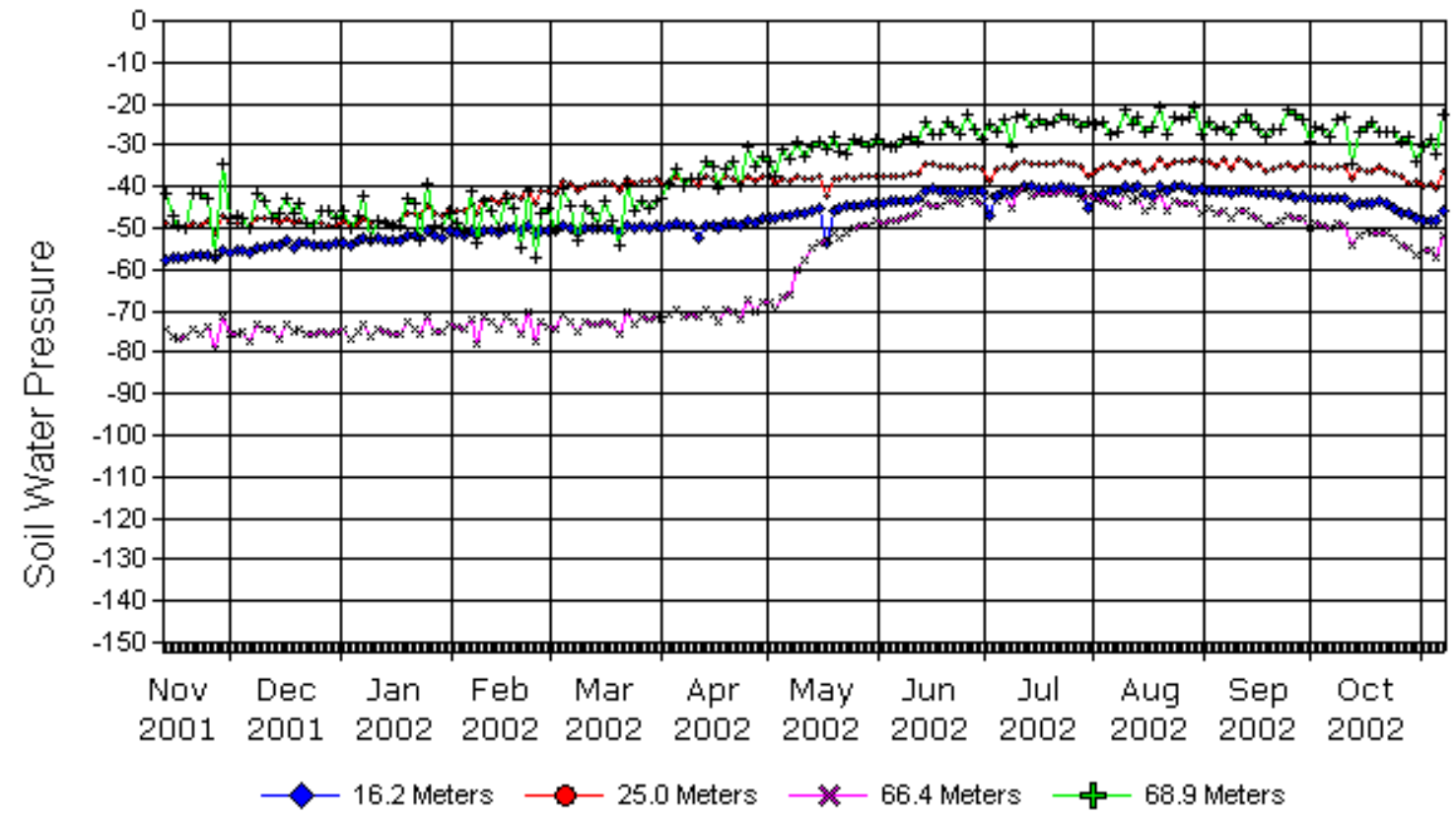

Figure 3.5. Soil Water Pressure Data: (a) Shallow and (b) Deep Sensors. Data are reported in cm of water pressure.

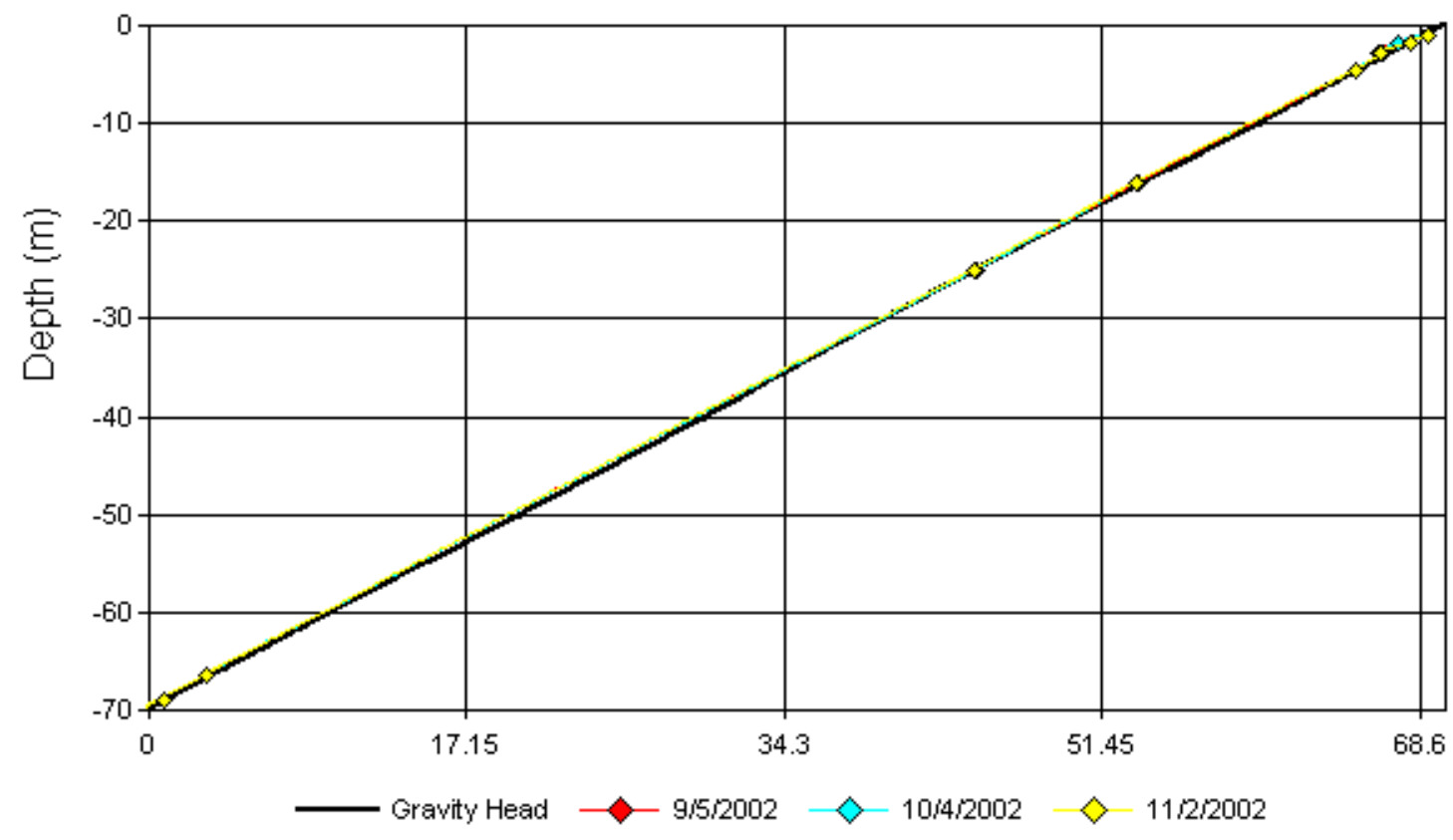

Figure 3.6. Total Head at Well C3360 


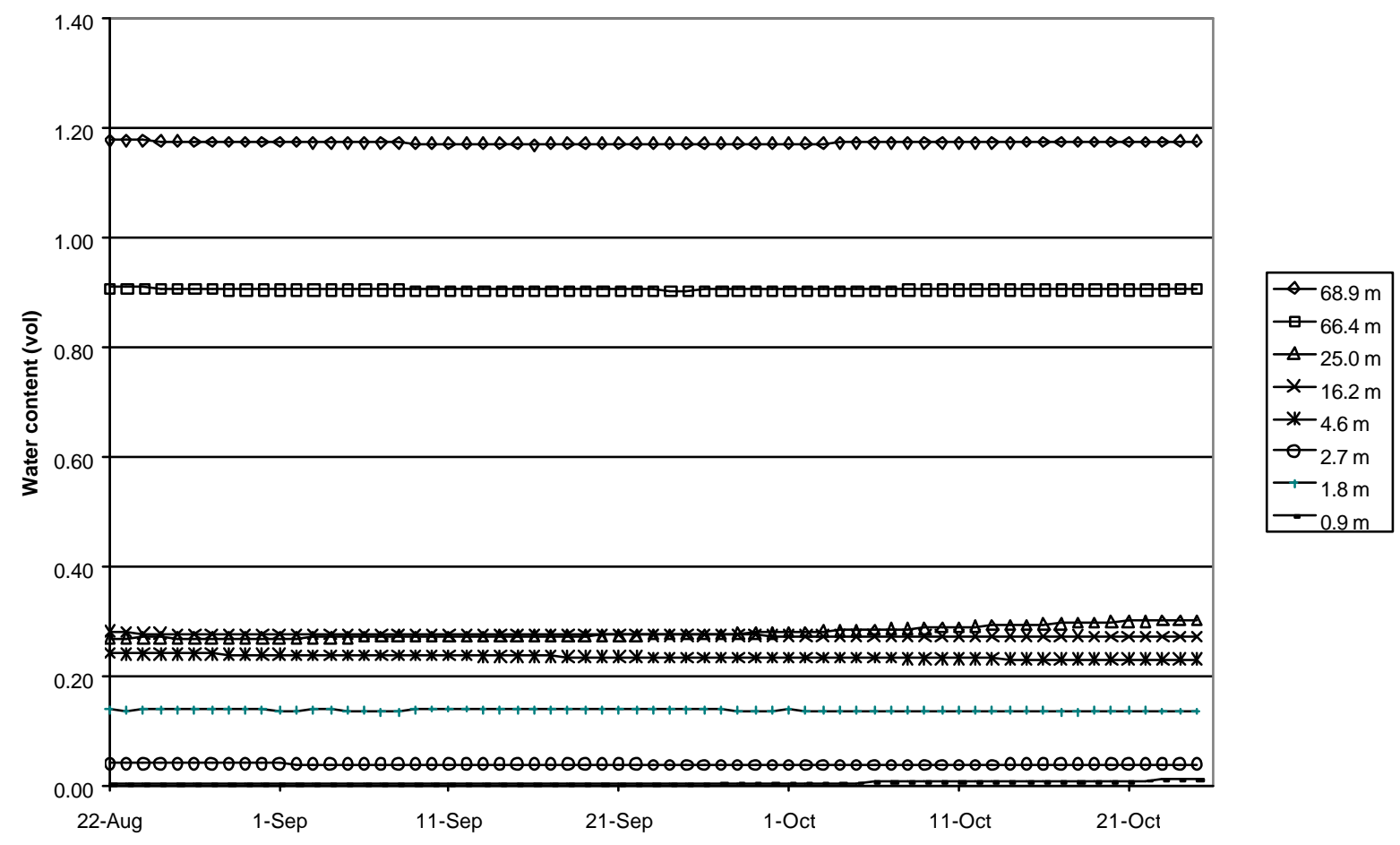

Figure 3.7. Water Content in Borehole C3360, near Tank B-110, from August Through October, 2001

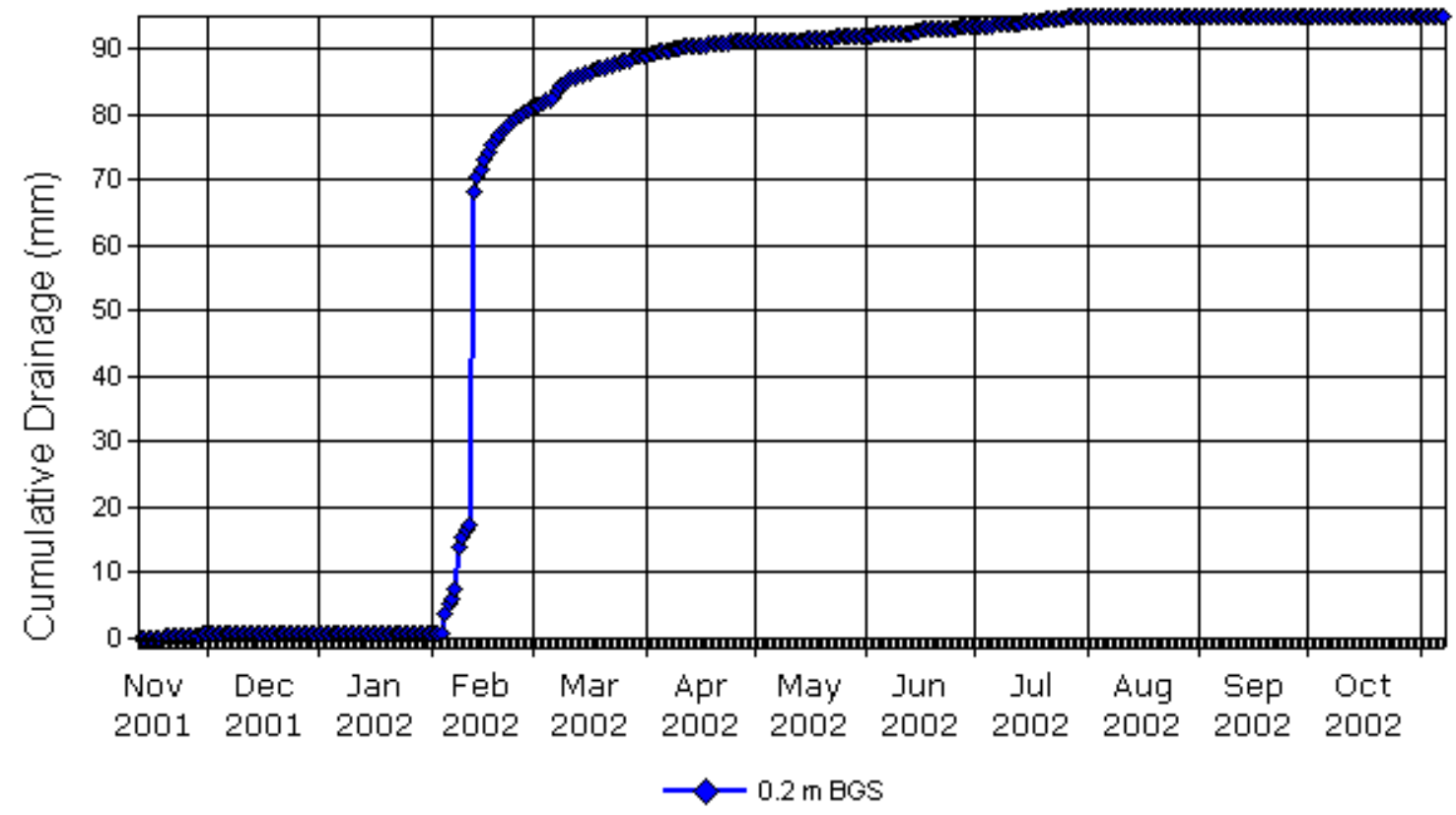

Figure 3.8. Drainage as Measured by the Water Fluxmeter 


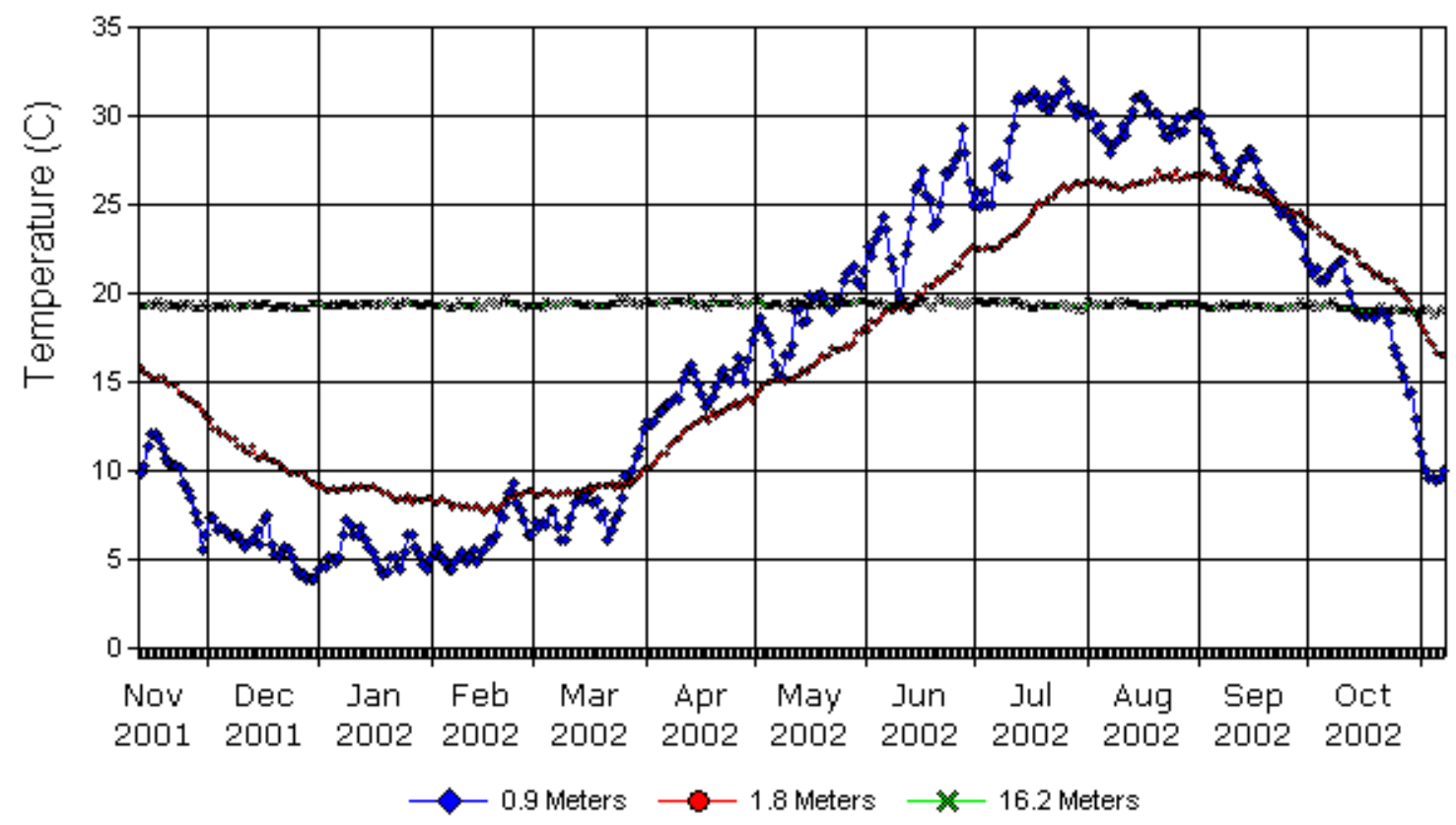

Figure 3.9. Near Surface Soil Temperature Changes over Time

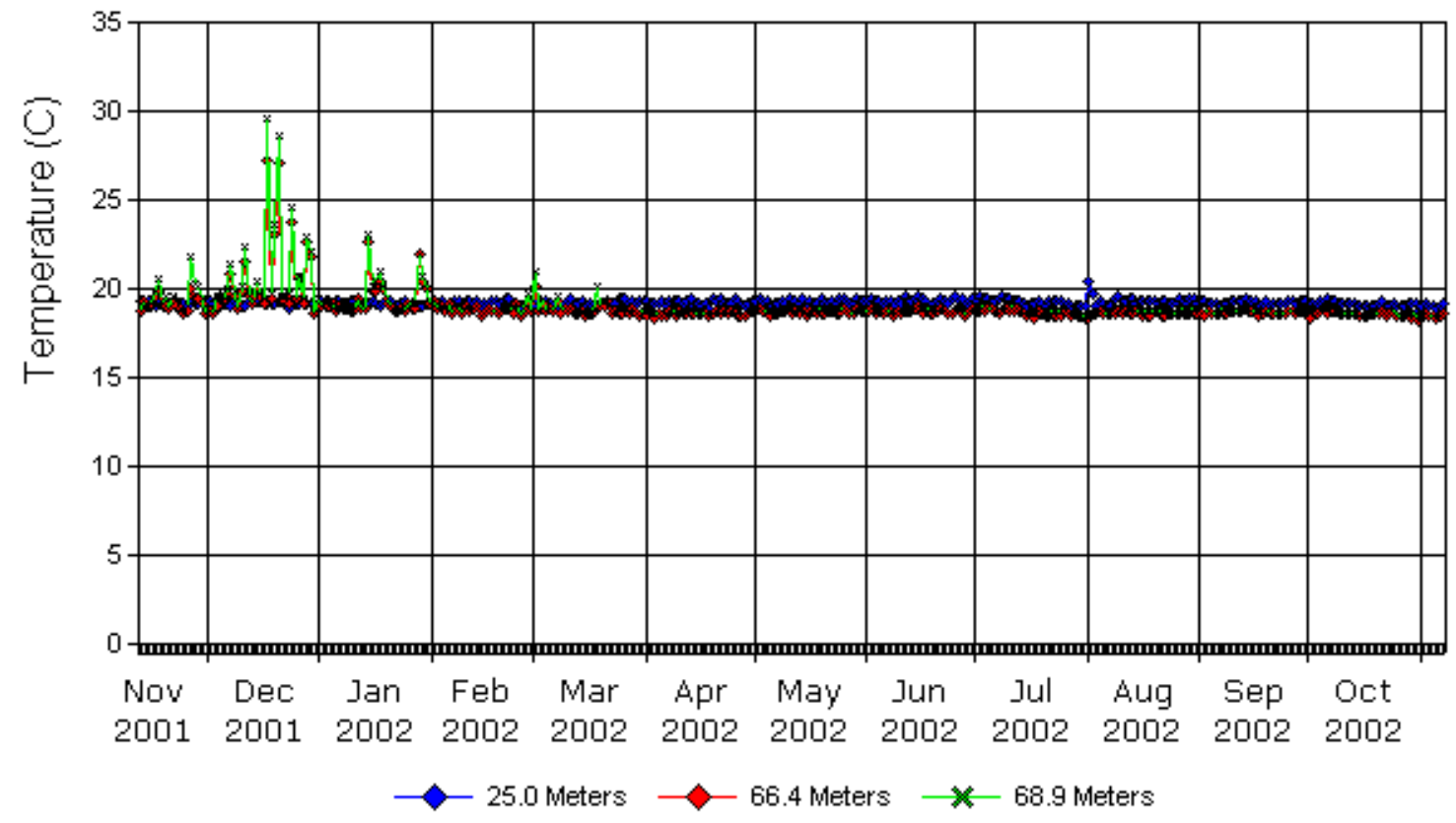

Figure 3.10. Soil Temperature Changes over Time at Depth

Solution samples were taken five times from February 2002 through September 2002. Vacuum was applied, and approximately $500 \mathrm{~mL}$ of sample was taken from each of 5 solution samples at depths indicated in Table 3.1. Vacuum in the range from -540 to -609 mbar was applied, and the sensors were 
sealed and allowed to pull water in from the silica slurry. It was found that the initial samples contained largely slurry water that was not in equilibrium with the formation waters. After five samples over the course of nearly 7 months, the solution water appeared to be in much closer in equilibrium with the chemistry of the formation water. Samples are currently being run to quantify the chemistry of the formation pore water and compare it with the most current solution samples. These data will be reported at a later date.

The B Farm deployment is the first installation of the VZMS in the sands and gravels at Hanford. Previous installations have been in finer textured materials or in rock. Information gained from the B Farm installation will provide guidance for modifying sensor placement to better track changes in water content. A preliminary examination of the data collected at the B110 borehole indicates abnormally high water-content readings at the 66.4- and 68.9-m (218- and 226-ft) depths. Because of the uncertainties of the water contents with depth, the data collection for water contents was not continued. Periodic checks of these data over the next several years will be used to test the stability of the sensors for sensing water content, pressure, and water flux.

\subsection{TX Tank Farm}

Only limited data have been collected from TX tank farm. The sensors were installed in September and early October, 2002. AT data are shown in Figure 3.11. The data indicate that the soil water pressures are in a range similar to those found at the 300-N Site and the B Tank Farm. The hydraulic head data shown in Figure 3.12 indicate that for this time period, the total head is unit gradient so that drainage should be expected at this site. Temperature data are shown in Figure 3.13. It appears that two of the four thermocouple sensors that were installed in the TX Tank Farm were severed and not functioning. The other two sensors are operational and appear to indicate normal temperature conditions. Data from the two water flux meters at TX tank farm collected during the month of October, 2002 indicated that no drainage had occurred during the first month of operation. Howver, it is expected fully expected that drainage will be observed during the coming winter months.

The tensiometers used in the B and TX Tank Farm installations are of a new (single shot) design. The new design was done to provide a surface completion such that no pipe or casing would protrude above ground surface. Previous VZMS installations had access tubes from the tensiometers that protruded above ground surface. The access tubes provided for refilling and purging gases from the tensiometer. However, experience from the $300 \mathrm{~N}$ test has shown that the tensiometers were capable of operating over extended periods without accumulating excessive volumes of soil gases. This experience led to the new design. Thus, it is recommended that the performance of the new design be evaluated for possible further improvements. After the B Farm installation, the design of the tensiometer was simplified (figure 2.4), although it is still more complex than the original AT design (see section 2, figure 2.1). Also, the new single shot design cannot be easily retrieved. 


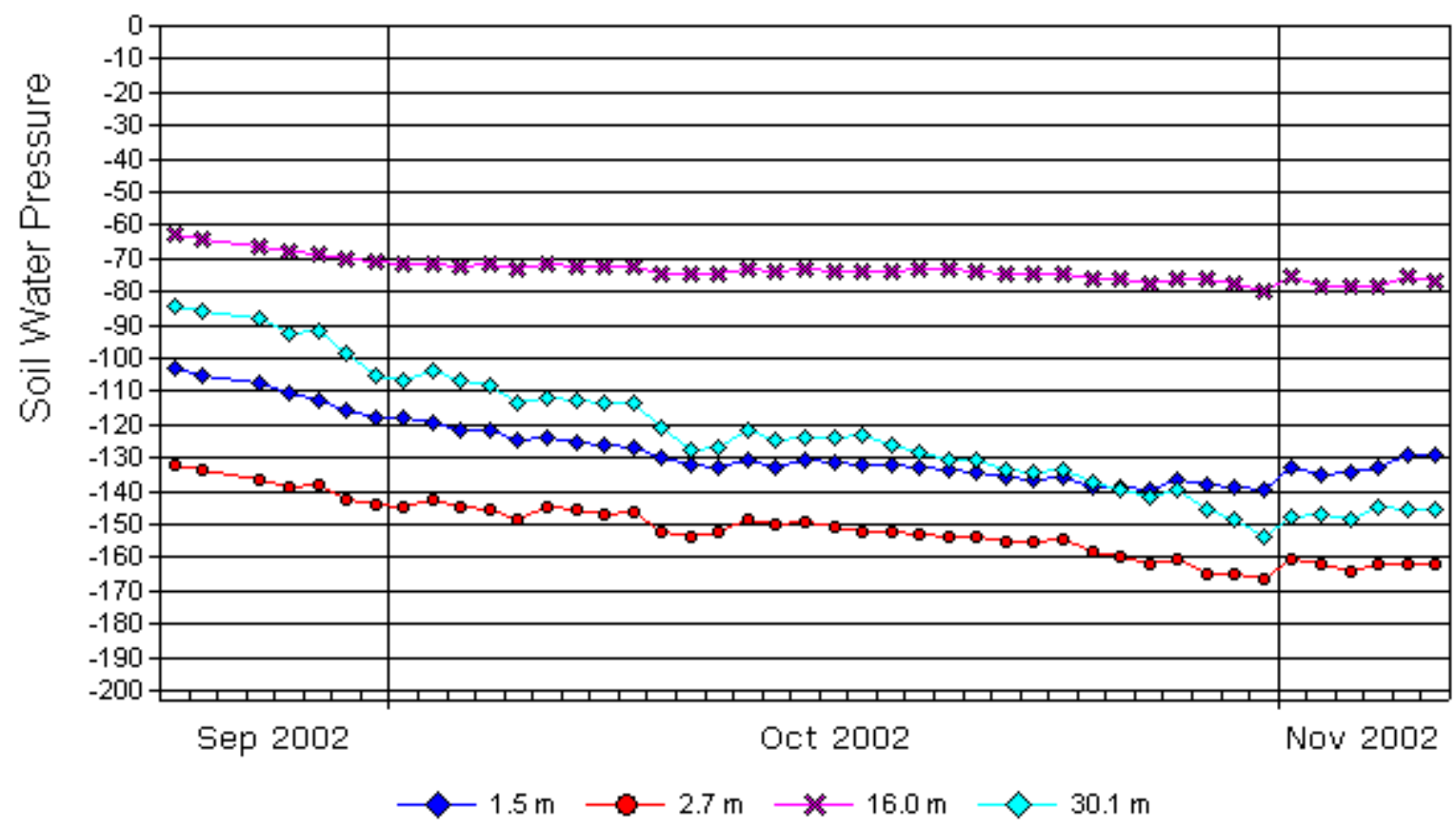

Figure 3.11. AT Data at Borehole C3830 TX Tank Farm, Soil Water Pressure. Data are reported in cm of water pressure.

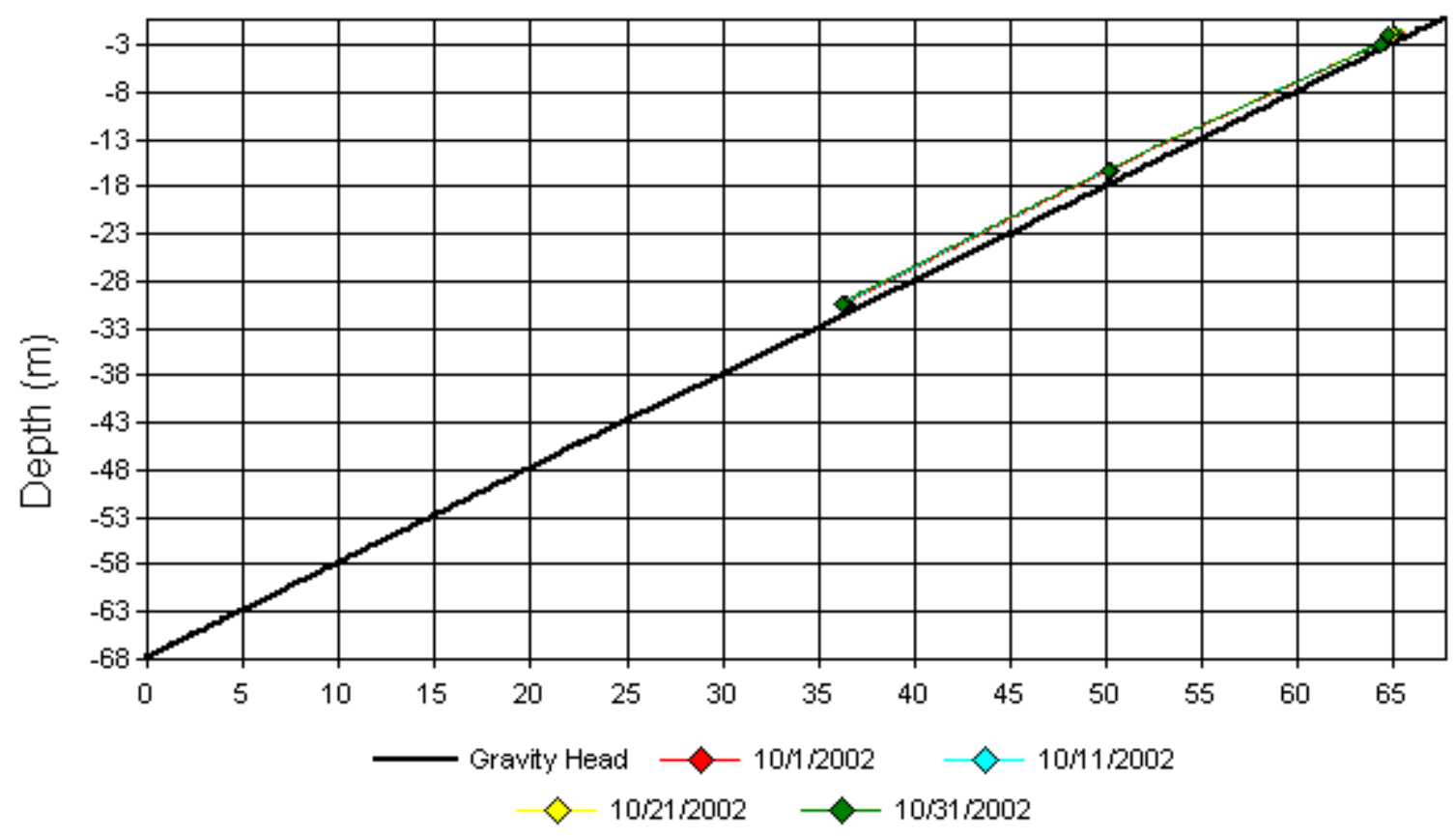

Figure 3.12. Hydraulic Head Data at Borehole C3830 in TX Tank Farm 


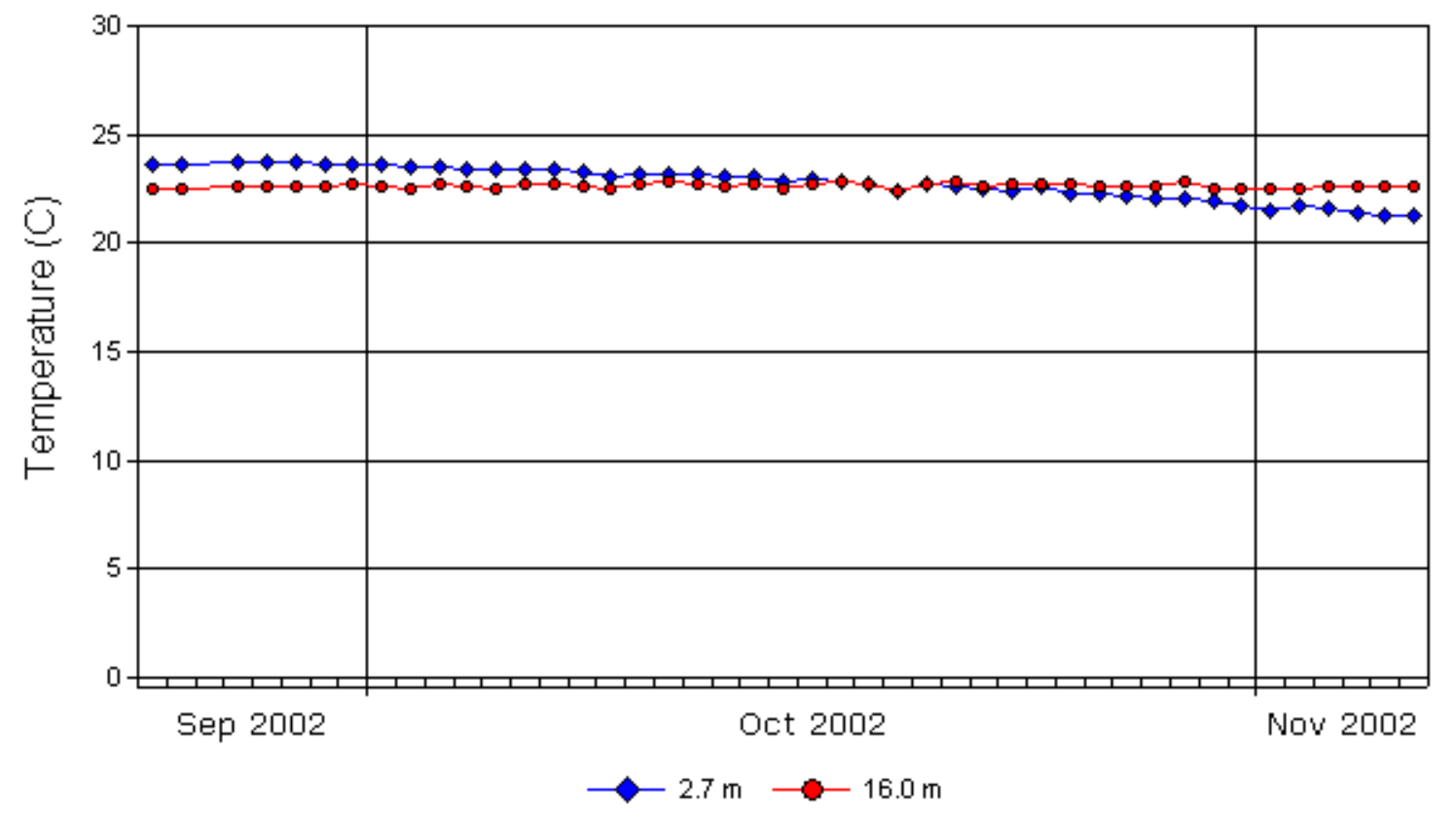

Figure 3.13. Temperature Data at Borehole C3830 in TX Tank Farm

The inclusion of temperature sensors into the VZMS assembly at B and TX tank farms is also a first for tank farm monitoring since prior to the VZMS installations, no soil temperature data were collected directly in the sediments in the tank farms. In general the thermal profiles at the B and TX tank farms appear to be relatively unaffected by any heat generated from the tanks at these locations.

Installation of vadose zone monitoring equipment within a given tank farm continues to be challenging. Limited borehole size ( 7 inch diameter) in TX restricted the placement of sensors within the borehole compared to B tank farm. No water content sensors and no solution samplers were placed in the TX borehole largely due to size limitations.

Placement of the two water fluxmeters at the perimeter of the TX tank farm made the installation easier at TX than at B tank farm. This arrangement also allows the units to be serviced easier than if the sensors were placed within the tank farm. Data loggers and peripheral equipment can also be serviced easier when the monitoring station is on the external side of the perimieter fence. Because the surface materials over the water fluxmeters are similar to the TX tank farm surface, it is expected that the drainage obtained from the water fluxmeters will be representative of the tank farm surface. Data collected from the fluxmeters over the next several years should prove to be invaluable in assessing the recharge potential for this site. The TX tank farm, like all other tank farms at Hanford is covered with bare, coarse, gravel materials and thus we expect a significant fraction of winter precipitation to drain. Drainage data from the two water fluxmeters should provide a reasonable estimate of the variation in drainage expected for the tank farm. The water fluxmeter performance has been optimized for tank farm conditions, where soils are coarse and surfaces are bare. Studies at the Field Lysimeter Test Facility (Fayer et al. 1999) located near the Hanford Meterological Station, about $4 \mathrm{~km}$ from the TX tank farm, 
have provided general information about expected drainage from bare, coarse, gravel surfaces under Hanford climatic conditions. The data generated from the Field Lysimeter Test Facility (FLTF) tests have provided the basis for current estimates for tank farm recharge (drainage). The actual collection of drainage with water fluxmeters at TX will be useful in verifying the recharge estimates from the FLTF lysimeters and the predictions of Gee and Ward (2002). Because the predictions of recharge require surface soil texture (percent fines) information, it will be desirable to collect surface soils from the perimeter and also within the tank farm to determine the variability in the surface texture of the tank farm.

Performance of vadose monitoring systems at the $300-\mathrm{N}$ site, the B Tank Farm, and the TX Tank Farm have met expectations to date but will need to be monitoried and serviced regularly over the next several years to assess the overall utility of these installations. The sensors, specifically the tensiometers have generally proven to be robust, with only minor instrumentation problems. Tensiometer and drainage data from the $300 \mathrm{~N}$ site have been used to successfully evaluate the hydraulic properties of Hanford formation sand materials. The $300 \mathrm{~N}$ test site has also proven to be useful for comparing performance of different sensors, including the advanced tensiometer placed by auger and the drive cone tensioimeter placed by CPT techniques. Both designs have performed well for nearly three years and have required only minimal maintenance. Water fluxmeters are relatively new vadose zone monitoring instruments but should prove to be robust and capable of producing reliable and long-term records of drainage under tank farm conditions. 


\subsection{References}

CH2M HILL Hanford Group, Inc. (CH2MHILL). 2000. Site Specific SST Phase 1 RFI/CMS Work Plan Addendum for WMA B-BX-BY, RPP-6072, Rev.1, Richland, Washington.

Fayer. M. J., E. M. Murphy, J. L. Downs, F. O. Khan, C. W. Lindenmeier, and B. N. Bjornstad. 1999. Recharge Data Package for the Immoblized Low-Activity Waste 2001 Performance Assessment. PNNL-13033, Pacific Northwest National Laboratory, Richland, Washington.

Gee GW, and TL Jones. 1985. Lysimeters at the Hanford Site. Present Use and Future Needs. PNL-5578, Pacific Northwest National Laboratory, Richland, WA.

Gee GW, MJ Fayer, ML Rockhold, and MD Campbell. 1992. "Variations in recharge at the Hanford Site.” Northwest Sci. 66:237-250.

Gee GW, AL Ward, TG Caldwell, and JC Ritter. 2002a. "A vadose-zone water fluxmeter with divergence control.” Water Resour. Res. 38(8) 10.1029/2001WR00816,2002.

Gee GW, JS Carr, JO Goreham, and CE Strickland. 2002b. Water Monitoring Report for the $200 \mathrm{~W}$ Area Tree Shelter Belt, Hanford Site, Richland, Washington, PNNL-14074, Pacific Northwest National Laboratory, Richland, WA.

Gee GW, and AL Ward. 2002. "Predicting Deep Drainage Using Soil Hydraulic Properties and Soil Texture Data." 9 pp. In. Transactions of the $17^{\text {th }}$ World Congress of Soil Science, Bangkok, Thailand, August 2002 (Electronic disk).

Gephart RE. 2001. A Short History of Hanford Waste Generation, Storage, and Release. PNNL13605, Rev. 1, Pacific Northwest National Laboratory, Richland, WA.

Gephart RE, and RE Lundgren. 1998. Hanford Tank Cleanup: A guide to understanding the technical issues. Battelle Press, Columbus $\mathrm{OH}$.

Hubbell JM, and JB Sisson. 1996. "Portable tensiometer use in deep boreholes." Soil Sci. 161: 376-381.

Hubbell JM, and JB Sisson. 1998. "Advanced Tensiometer for shallow or deep soil water pressure measurements," Soil Sci. 163: 271-277.

Johnson VG, and CJ Chou. 2001. RCRA Groundwater Quality Assessment Report for Waste Management Area S-SX (November 1997 through April 2000), PNNL-13441, Pacific Northwest National Laboratory, Richland, WA. 
Reece CF. 1996. "Evaluation of a line heat dissipation sensor for measuring soil matric potential." Soil Sci. Soc. Am. J. 60: 1022-1028.

Rockhold ML, MJ Fayer, and G W Gee. 1988. Characterization of Unsaturated Hydraulic Conductivity at the Hanford Site, PNL-6488, Pacific Northwest Laboratory, Richland, WA.

Sisson JB, and JM Hubbell. 1999. "Soil water pressure to depths of 30 meters in fractured basalt and sedimentary interbeds," pp 855-865. In M. Th. van Genuchten, F. J. Leij and L. Wu. (eds.), Proceedings of the International Workshop on Characterization and Measurement of the Hydraulic Properties of Unsaturated Porous Media. Oct 22-24, 1997, Riverside, CA, University of California, Riverside Press.

Sisson JB, GW Gee, JM Hubbell, WL Bratton, JC Ritter, AL Ward, and TG Caldwell. 2002. “Advances in tensiometry for long-term monitoring of soil water pressures" Vadose Zone J. (Nov. Issue).

Ward AL, GW Gee, and SO Link. 1997. Hanford Prototype-Barrier Status Report: FY 1997, PNNL-11789, Pacific Northwest National Laboratory, Richland, WA. 


\section{Appendix A}

\section{Duratek Water Well Report for C-3360 (299-E33-46)}


Durcatek

August 20, 2001
Duratek Federal Services, Inc. Northwest Operations 345 Hills Street Richland, Washington 99352

(509) 376-7055 - Phone (509) $372-1435$ - Fox

MGG-01-1616

Mr. Joe A. Caggiano

State of Washington

Department of Ecology

1315 West $4^{\text {th }}$ Avenue

Kennewick, Washington 99336

Dear Mr. Caggiano:

\section{WATER WELL REPORT}

Enclosed is a Water Well Report for geotechnical boring C3360 (299-E33-46). This well is located in the 200 East Area, B Tank Farm. Boring C3360 was completed per WAC 173-160 requirements and discussions with the State of Washington Department of Ecology.

Please reference Start Card number S00615 (Notice of Intent to Construct a Geotechnical Soil Boring).

Should you have any questions, please contact me at (509) 372-8029.

Very truly yours,

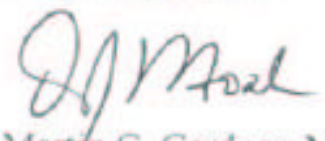

Martin G. Gardner, Manager

Sampling and Well Services

jal

Enclosure

$\begin{array}{ll}\text { CHG } & \text { - J. E. Auten } \\ & \text { A. J. Knepp } \\ & \text { H. A. Sydnor } \\ \text { DFSNW } & - \text { K. D. Reynolds } \\ & \text { D. E. Skoglie } \\ & \text { S. H. Worley } \\ & \text { MGG File/LB } \\ & \text { CHG/772028/305 }\end{array}$


File Original witt Desortment of Ecology Second Cooy - Omrer's Copy Thirs Copy - Driler's Copy
WATER WELL REPORT

STATE OF WASHENGTON
Notice of intans $\mathrm{S} 00615$

UNaOUE WELL $1.0,299-533-46$

Water Hight Parmit Na N/A

Page lof 3

(1) OWNer: Name U.S. Departnent of Energy Adews 825 Jadwin Ave., Richland, WA 99352

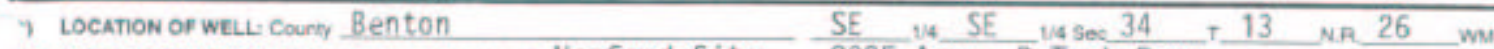

(2a) STREET ADOREss of WELL: (or nearast address) Hanford Site $200 E$ Ared, B Tank Farm TAX PAACEL NO. N/A

\begin{tabular}{|c|c|c|c|c|}
\hline 3 & PAOPOSED USE; & 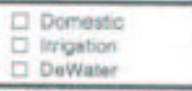 & $\begin{array}{l}\text { O industrial } \\
0 \text { Test Well }\end{array}$ & $\begin{array}{l}\text { Municipal } \\
\text { Other }\end{array}$ \\
\hline (4) & TYPE OF WOAK: & $\begin{array}{l}\text { Pwners nombet of } \\
\text { X New Weil } \\
\text { Deeepened } \\
\text { D Recondtioned } \\
\text { Deconiasion }\end{array}$ & $\begin{array}{l}\text { ell (f) more than onel } \\
\text { Method: } \\
\text { D Dug } \\
\text { X Cabies } \\
\text { D Aotary }\end{array}$ & 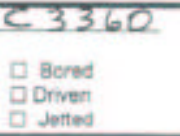 \\
\hline (5) & $\begin{array}{l}\text { DIMENSIONS: } \\
\text { Dilled_264.2 }\end{array}$ & $\begin{array}{l}\text { Dismentor of wel - } \\
\text { fuet. Depth of comp }\end{array}$ & $\begin{array}{l}11.75 \\
\text { enod wat } 226.0\end{array}$ & \\
\hline (6) & 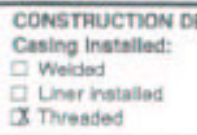 & $\begin{array}{l}\text { TAlLS } \\
13.375 \\
10.75\end{array}$ & $\begin{array}{l}\text { Diam from } 9 \\
\text { Diwn from } 0 \\
\text { Diwn from }\end{array}$ & 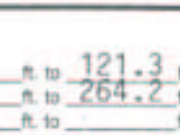 \\
\hline
\end{tabular}

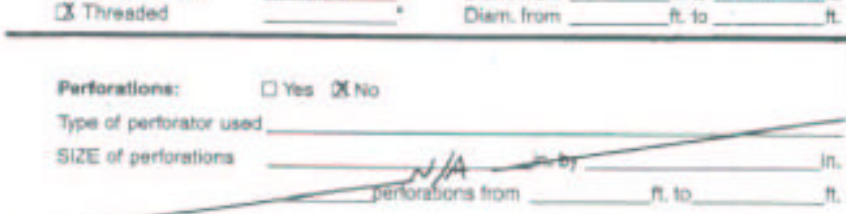

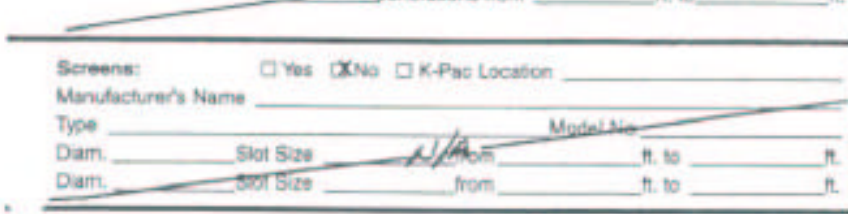

\begin{tabular}{|c|c|c|}
\hline GraveiFititer packed: & DYos DXNo & DSize of graveivsand \\
\hline Meriental placed from_ & 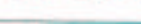 & in. 10 \\
\hline
\end{tabular}

\begin{tabular}{|c|c|c|}
\hline & $\begin{array}{l}\text { Surtace seat: } \\
\text { Material used in seal }\end{array}$ & To what depen? $\frac{\text { See As-Built }}{\text { Condition }}$ \\
\hline & $\begin{array}{l}\text { Did any strata contain unusabie water? } \\
\text { Dype of water? }\end{array}$ & $\begin{array}{l}\text { II Yes DNo } \\
\text { Depth of strata }\end{array}$ \\
\hline & Method of saaling strata of & \\
\hline (7) & PUMP: Manulacturars Nane $\mathrm{N} / \mathrm{A}$ & \\
\hline & Type: - & H.R \\
\hline
\end{tabular}

(8) WATER LEVELS: Land-surtace elevation above mean saa level 657.3

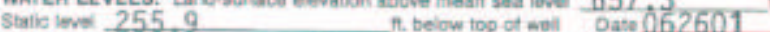
Arnesian pressure Artesian water is controlad by N/A (Cap, valve, ette)

(9) WELL TESTS: Drawdown is amount watar level is lowered below static leve Was a pump teal mado? DYas $X$ No If yes, ty whom?

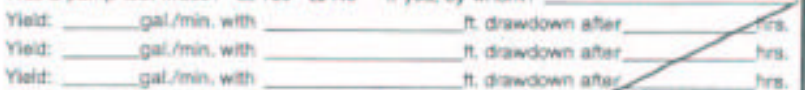
Recovery data (time taken as zero when pump sumed off (wabejel sil measured from wel top to water level

Time Water Level Time Warelfives Time Water Level

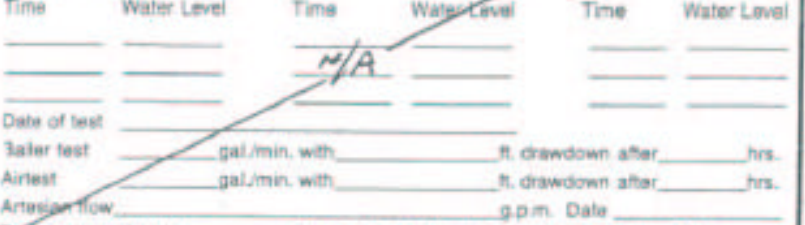

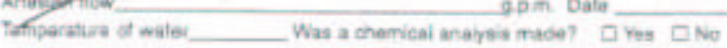

ECY 050.1.20 (11/9e)

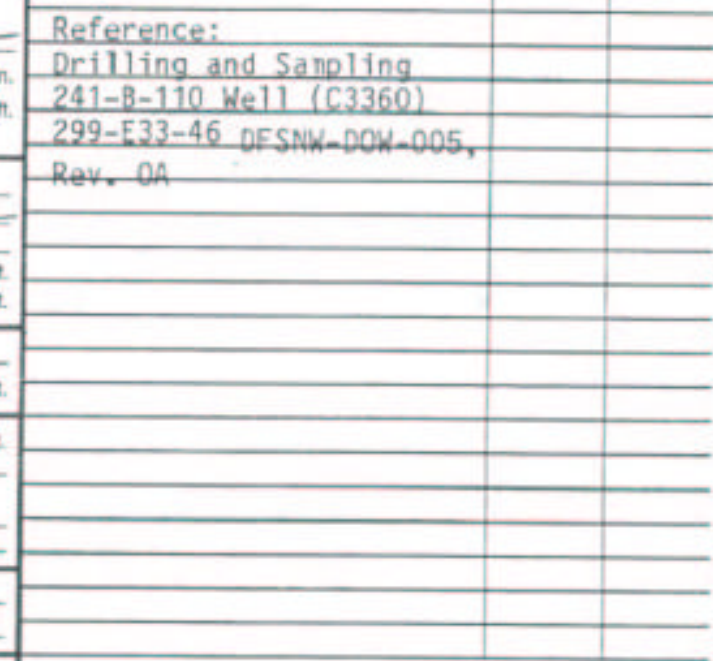

Woks stantad April 10, 2008mpieteo July 31, 2001

WELL CONSTAUCION CEATIFICATION:

I constructad andior accost resporsiblilty for construction of this well, and its compliance win at Washingten wat construction standards. Materlais used and the information reoorted above are true to my beat knowledoe and beief

The or Print Name Ke 1 ly 01 son woense No 1217 Ricaraed DrilientEnginear)

Tainee Name N/A License No. Driting Compary Resonant Sonicint.

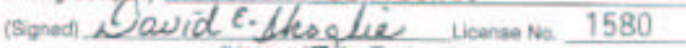
(uicensectofier Engineen)

Addess 345 Hills ST, Richland, WA 9935?

Contaciors

Pagistration Na RSONI*016L5 Dase OS1601 CUSE ADOITIONAL SHEETS IF NECESSAAY

Ecology is an Equal Opporturity and Affimative Action amployer. For specia accemmodascon needs, contact the Water Feiources Progarn at (360) 407 . 6600 . The TOD number is $(360)+407+0006$ 


\section{WATER WELL REPORT \\ STATE OF WASHINGTON}

Page 2 of 3

\section{As Built Condition:}

1) $133 / 8$ inch casing was drilled to a depth of $121.3 \mathrm{ft} \mathrm{BGS}$. Sediment samples were collected by split spoon and grab methods. Radiological contamination was noted from $44.7 \mathrm{ft}$ BGS to $86.2 \mathrm{ft}$ BGS utilizing field instrumentation.

2) Geophysical Logging and analysis was conducted (Gross gamma, Spectral High Purity Germanium HpgE, and Neutron-Moisture) inside the $133 / 8$ casing annulus.

3) $10 \%$ inch casing was drilled to a depth of $264.2 \mathrm{ft}$ BGS. Sediment samples were collected by split spoon and grab methods.

4) The water level was $255.9 \mathrm{ft}$ BGS (062601). A temporary sereen was set, casing back pulled, and a water sample obtained.

5) Geophysical Logging and analysis was conducted (Gross gamma, Spectral High Purity Germanium HpgE, and Neutron-Moisture) inside the $10 \%$ casing annulus

6) The geotechnical boring was decommissioned with sand to a depth of $253.7 \mathrm{ft}$ BGS while back pulling casing. Bentonite crumbles were placed to a depth of $228.3 \mathrm{ft}$ BGS while back pulling casing. Sand $(10-20)$ was placed to a depth of $227,9 \mathrm{ft}$ BGS.

7) Number 8 sensor array (Advanced Tensiometer, Solution Sampler, Heat Dissipation Sensor, and Water Content Sensor) was set @ a depth of $226 \mathrm{ft}$ BGS. Silica flour $/$ sand was placed to a depth of $225.2 \mathrm{ft}$ BGS. Sand was placed to a depth of $223.7 \mathrm{ft}$ BGS. Bentonite pellets were added to a depth of $220.8 \mathrm{ft}$ BGS while back pulling casing.

8) Sand (10-20) was placed to a depth of $219.1 \mathrm{ft}$ BGS.

9) Number 7 sensor array (Advanced Tensiometer, Solution Sampler, Heat Dissipation Sensor, and Water Content Sensor) was set @ a depth of $218 \mathrm{ft}$ BGS. Silica flour $/$ sand was placed to a depth of $215.8 \mathrm{ft}$ BGS. Sand was placed to a depth of $211.7 \mathrm{ft}$ BGS while back pulling casing.

10) Bentonite crumbles were placed to a depth of $124.2 \mathrm{ft}$ BGS while back pulling casing. The remaining $10 \%$ inch casing was removed from the bore hole.

11) Bentonite crumbles were placed to a depth of $85.5 \mathrm{ft} \mathrm{BGS}$ while back pulling the 13.375 inch casing.

12) Sand (10-20) was placed to a depth of $84.5 \mathrm{ft} \mathrm{BGS}$

13) Number 6 sensor array (Advanced Tensiometer, Heat Dissipation Sensor, and Water Content Sensor) was set @ a depth of $82 \mathrm{ft}$ BGS. Silica flourisand was placed to a depth of $79.6 \mathrm{ft}$ BGS.

14) Bentonite crumbles were placed to a depth of $56.5 \mathrm{ft}$ BGS while back pulling casing.

15) Sand (10-20) was placed to a depth of $55.3 \mathrm{ft}$ BGS.

16) Number 5 sensor array (Advanced Tensiometer, Heat Dissipation Sensor, and Water Content Sensor) was set (a) a depth of $53 \mathrm{ft}$ BGS. Silica flour $/$ sand was placed to a depth of $45.3 \mathrm{ft}$ BGS.

17) Bentonite crumbles were placed to a depth of $20.4 \mathrm{ft}$ BGS while back pulling casing.

18) Sand (8-12) was placed to a depth of $16 \mathrm{ft} \mathrm{BGS.}$

19) Number 4 sensor array (Advanced Tensiometer, Heat Dissipation Sensor, and Water Content Sensor) was set @ a depth of $15 \mathrm{ft}$ BGS. Silica flour/sand was placed to a depth of $11.2 \mathrm{ft}$ BGS. Natural fill (bore hole collapse to $10 \mathrm{ft}$ BGS).

20) Number 3 sensor array (Advanced Tensiometer, Heat Dissipation Sensor, and Water Content Sensor) was set @ a depth of $9 \mathrm{ft}$ BGS. Sand (10-20) was placed to a depth of $7.2 \mathrm{ft}$ BGS

21) Number 2 sensor array (Advanced Tensiometer, Heat Dissipation Sensor, and Water Content Sensor) was set @ a depth of $6 \mathrm{ft}$ BGS. Sand (10-20) was placed to a depth of $4.7 \mathrm{ft}$ BGS.

22) Number 1 sensor array (Advanced Tensiometer, Heat Dissipation Sensor, Water Content Sensor, and

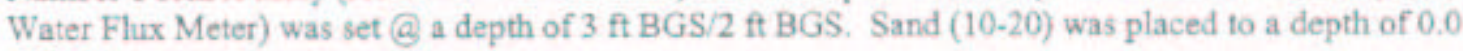
ft BGS.

23) The Sensor Arrays were wired and site secured. 


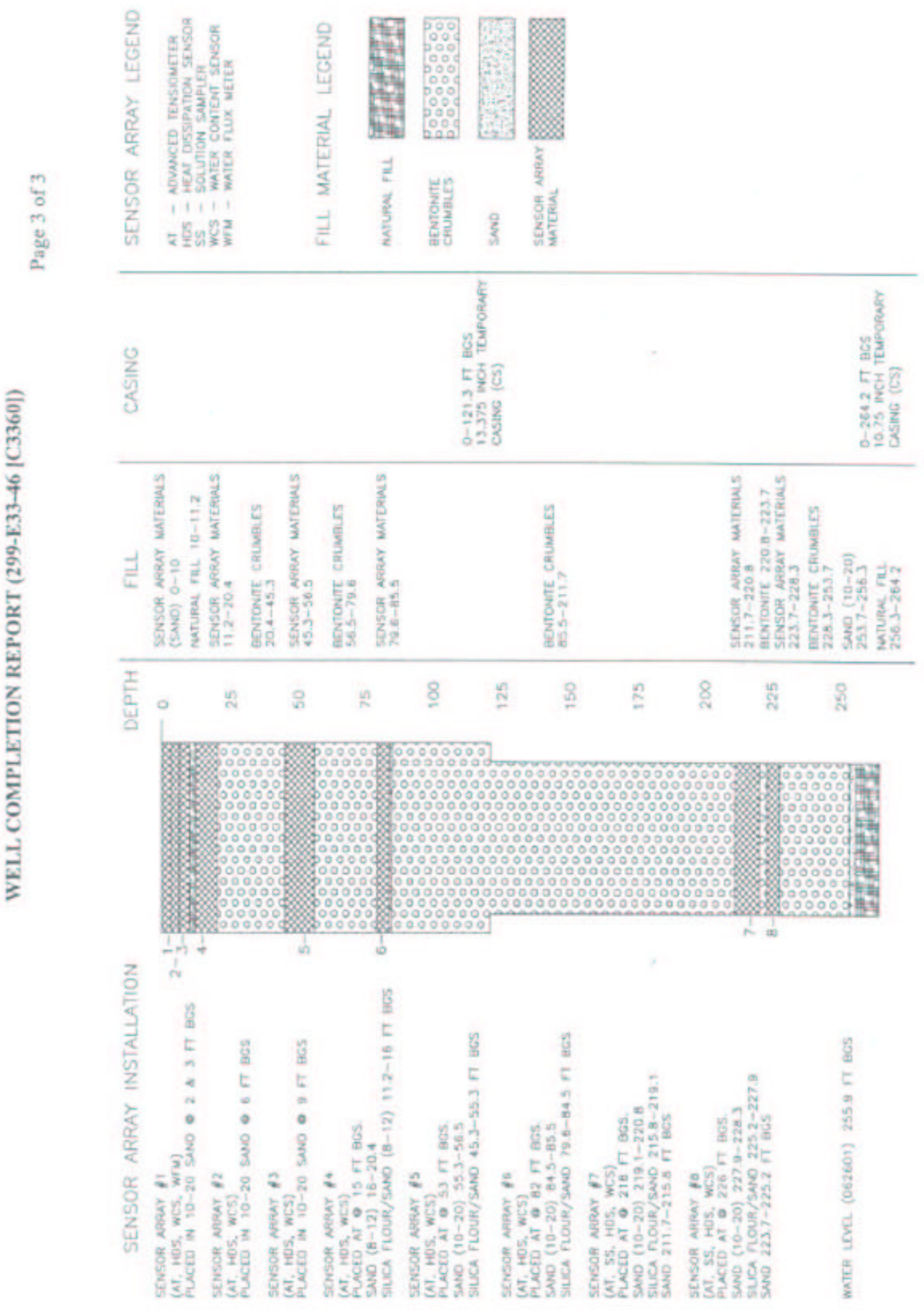




\section{Appendix B}

\section{Water Well Report for TX Tank Farm Borehole C3830}




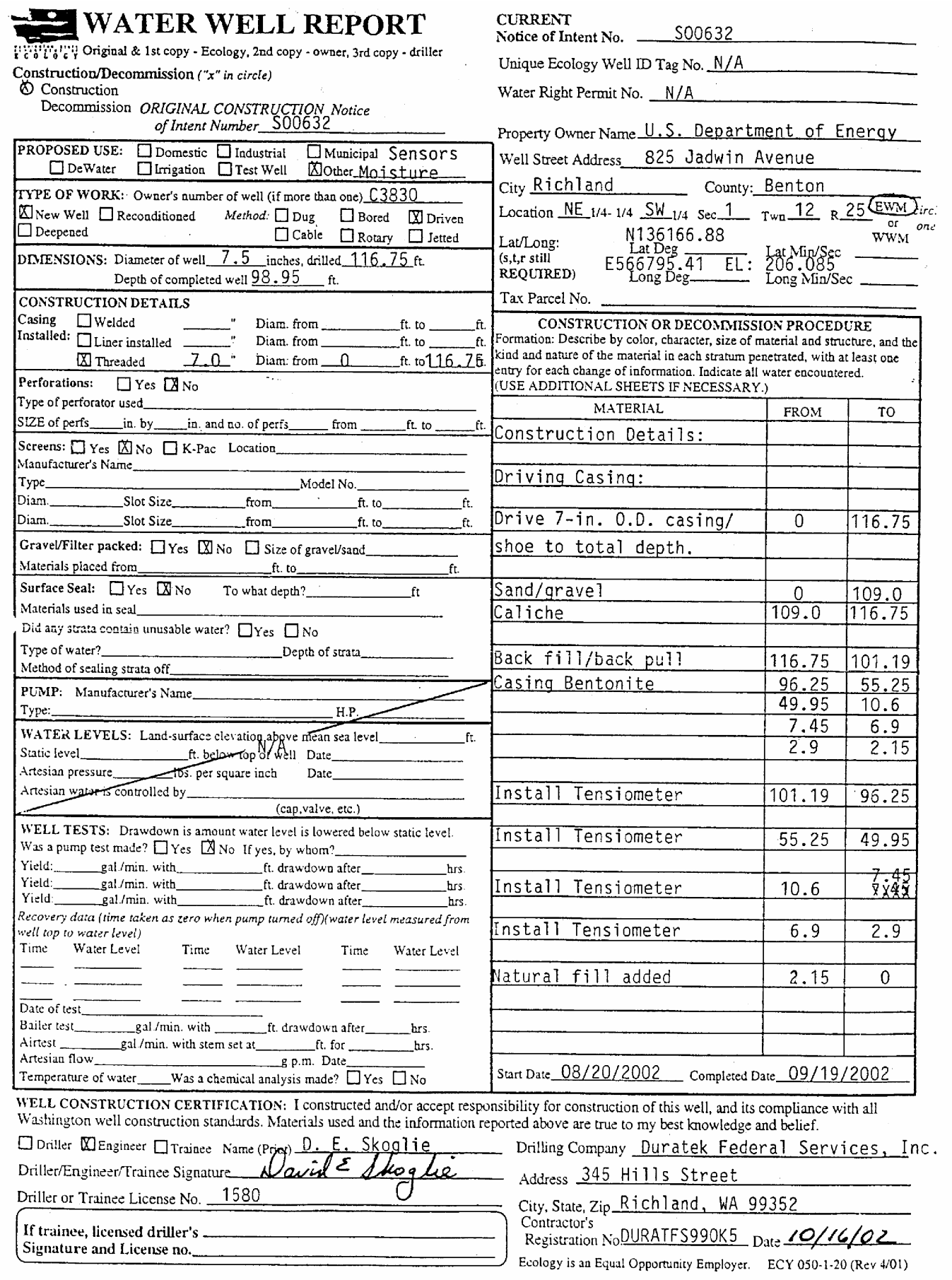

B. 1 


\section{Appendix C}

\section{Water Well Report for Tank Farm TX Water Fluxmeters - Geotechnical Borings C4089 and C4090}




\section{Duratek \\ Federal services}

October 17,2002
Duratek Federal Services, Inc. Northwest Operations

345 Hills Street

Richland, Washington 99352

(509) 376-7055 - Phone

(509) $372-1435 \cdot$ Fax

Mr. Joe A. Caggiano

State of Washington

Department of Ecology

1315 West $4^{\text {th }}$ Avenue

Kennewick, Washington 99336

Dear Mr. Caggiano:

\section{WATER WELL REPORT}

Attached are the Water Well Reports for geotechnical borings C4089 and C4090. These borings are located in the 200 West Area, Hanford Site.

These borings were completed per WAC 173-160 requirements and exemptions previously discussed with the State of Washington Department of Ecology, "WAC Exemption for Auger-installed Instrumentation at 200 West Area (TX Moisture Monitoring)," dated September 24, 2002.

Please reference Start Card Number S00635 regarding Notice of Intent to Construct a Geotechnical Soil Boring.

If you have any questions, please contact me at (509) 372-8029.

Very truly yours,

JMoin 6

M. G. Gardner, Manager

Sampling and Well Services

jmt

Attachment

$\mathrm{FH}$ - J. E. Auten

PNNL - G. W. Gee

DFSNW - M. C. Dorsey

D. E. Skoglie

S. H. Worley

MGG File/LB

PNNL/R41020 


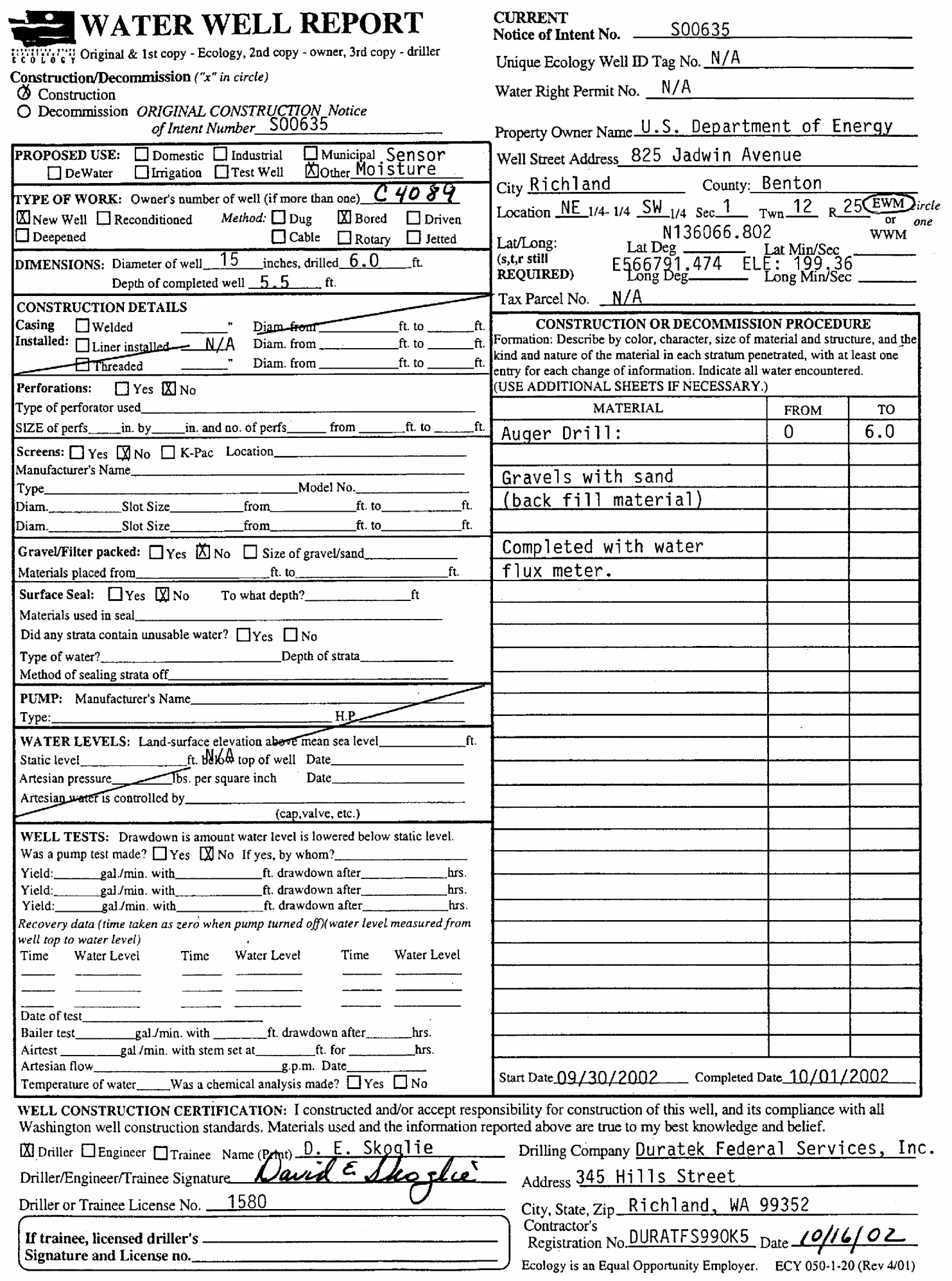




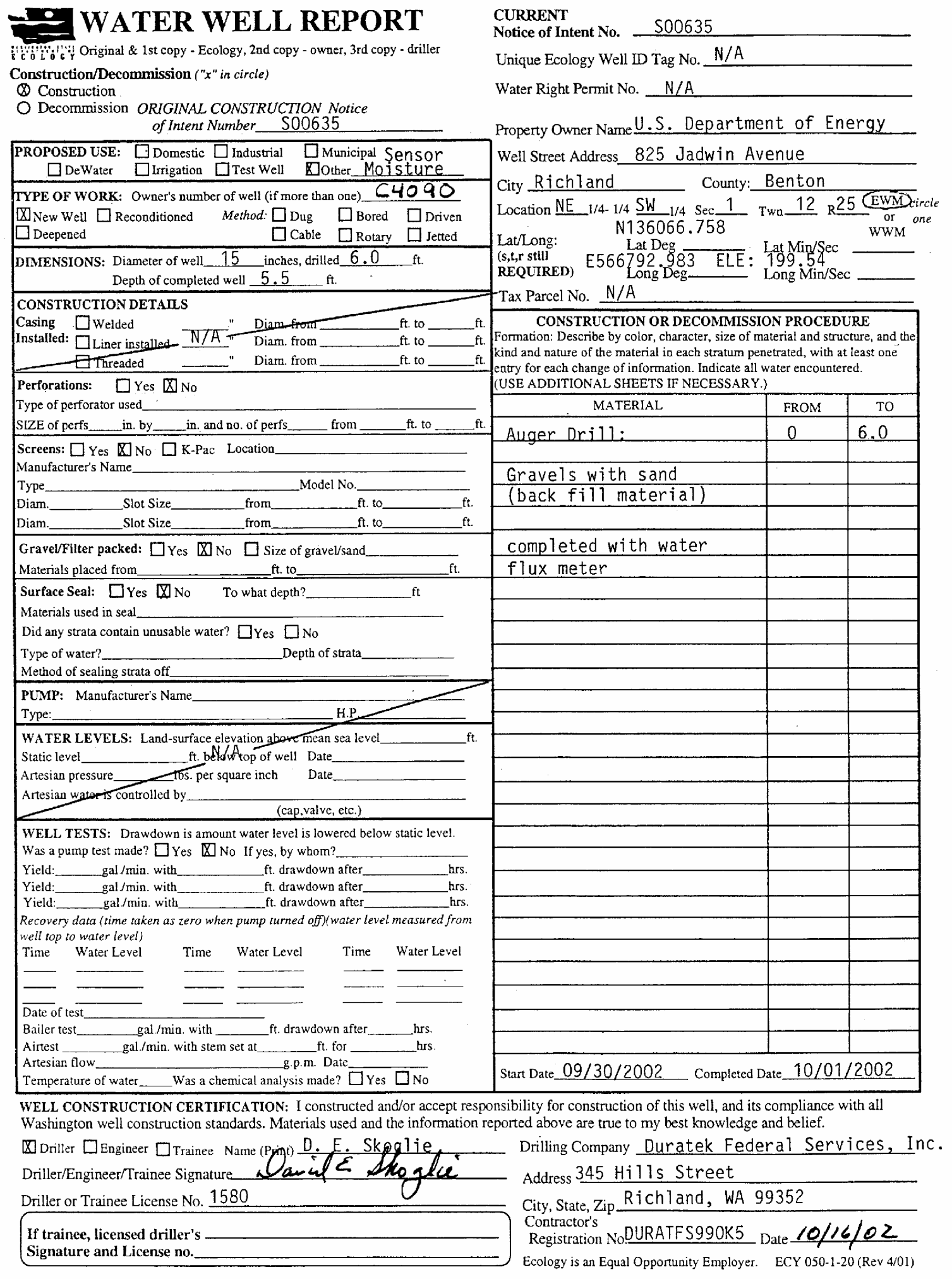


PNNL-14115

\section{Distribution}

No. of

Copies

OFFSITE

2 Lawrence Livermore National Laboratory

L-130

Livermore, California 94550

Attn: William D. Daily

Abe Ramirez

2 Lawrence Berkley National Laboratory

Department of Earth and Planetary Sciences

MS 4767

1 Cyclotron Road

Berkeley, California 94720-4767

Attn: Donald J. DePaolo

Mark Conrad

James B. Fink

HydroGEOPHYSICS, Inc.

5865 South Old Spanish Trail

Tucson, Arizona 85747

Marc Levitt

HydroGEOPHYSICS, Inc

586 Sout Old Spanish Trail

Tucson, Arizona 85747

Joel Hubbell

Idaho National Engineering and Environmental

Laboratory, BBWI

P.O. Box 1625, MS-2107

Idaho Falls, Idaho 83415-2107
No. of

Copies

\section{OFFSITE}

Jan W. Hopmans

Hydrology Program

Department of Land, Air and Water Resources

123 Veihmeyer Hall

University of California

Davis, CA 95616

Peter C. Lichtner

Los Alamos National Laboratory

Environmental Sciences Division (EES-5)

MS F-649

Los Alamos, New Mexico 87545

Brian J. Andraski

U.S. Geological Survey

333 W Nye Ln., Rm. 203

Carson City, NV, 89706

Ernest L. Majer

Lawrence Berkeley National Laboratory

1 Cyclotron Road (MS 90-116)

Berkeley, California 94720

Earl D. Mattson

Idaho National Engineering and Environmental Laboratory

P.O. Box 1625

2251 N. Boulevard

Idaho Falls, Idaho 83415-2107

Gregory A. Newman

Sandia National Laboratories

P.O. Box 5800

MS-0750

Albuquerque, New Mexico 87185-0750

Dist. 1 


\section{Distribution (Contd)}

No. of

Copies

\section{OFFSITE}

James B. Sisson

Idaho National Engineering and Environmental

Laboratory, BBWI

P.O. Box 1625, MS-2107

Idaho Falls, Idaho 83415-2107

John Baker

USDA-ARS

Department of Soil, Water, \& Climate

439 Borlaug Hall

University of Minnesota

1991 Upper Buford Circle

St. Paul, MN 55108

Alan and Lorrie Flint

US Geological Survey

Placer Hall

6000 J Street

Sacramento CA, 95819-6129

Rien van Genuchten

U.S. Salinity Laboratory

450 West Big Springs Road

Riverside, CA 92507-4617

John Nimmo

U.S. Geological Survey

345 Middlefield Road, MS-421

Menlo Park, CA 94025

Michael H. Young

Div. of Hydrologic Sciences, Desert Research

Institute

755 E. Flamingo Road, Las Vegas, NV 89119
No. of

Copies

OFFSITE

2 Los Alamos National Laboratory

Environmental Science Group

MSJ495

Los Alamos, New Mexico 87545

Attn: Everett P. Springer

Brent Neuman

P. J. Wierenga

Soil, Water, and Environmental Science

University of Arizona

Tucson, Arizona 85721

Michael Wilt

EMI

1301 S. $46^{\text {th }}$ St.

UCRFS Bldg. 300

Richmond, California 94804

T.C. Jim Yeh

University of Arizona

Department of Hydrology and Water Resources

The University of Arizona, Bldg. 11

Tucson, Arizona 85721

Bill Albright

Desert Research Institute

7010 Dandini Blvd.

Reno, NV 89506

Dirk Dunning, P.E.

Oregon Office of Energy

Nuclear Safety Division

625 Marion St. NE, Suite 1

Salem, OR 97301-3742

Dist. 2 


\section{Distribution (Contd)}

No. of

Copies

ONSITE

2 DOE Office of River Protection

C. A. BabelH6-60

R. M. Yasek H6-60

9 DOE Richland Operations Office

B. L. Foley

A6-38

J. P. Hanson

K8-50

R. D. Hildebrand

K. A. Kapsi

A5-13

K8-50

R. W. Lober

J. G. Morse

K. M. Thompson

R. M. Yasek

3 Bechtel Hanford Inc.

R. L. Biggerstaff

L. R. Curry

K. R. Fecht

7 CH2M Hill Hanford Group

J. W. Cammann

H6-22

A. J. Knepp

E6-35

E6-35

E6-35

D. A. Myers (5)

V. J. Rohay

E6-35

L. C. Swanson

E6-35

H. A. Sydnor (5)

E6-35

C. D. Wittreich

2 MACTER-ERS

J. F. Bertsch

B1-42

R. G. McCain

E6-35

B1-42
No. of

Copies

\section{ONSITE}

3 Waste Management Technical Services

M. G. Gardner

H1-11

J. E. Meisner

H1-11

R. K. Price

H1-11

6 Washington Department of Ecology

F. W. Bond

B5-18

J. Caggiano

B5-18

D. Goswami

B5-18

A. Huckaby B5-18

S. Leja

B5-18

N. H. Uziemblo

B5-18

1 U.S. Environmental Protection Agency

$$
\text { D. A. Faulk }
$$

B5-01

\section{Fluor Federal Services}

R. J. Fabre

X5-50

B. H. Ford

E6-35

T. W. Fogwell

E6-35

R. Jackson

E6-35

R. Khaleel

E6-17

R. T. Wilde

E6-35 


\section{Distribution (Contd)}

No. of

Copies

ONSITE

55 Pacific Northwest National Laboratory

B. Barnett

W. F. Bonner

R. W. Bryce

R. E. Clayton

P. W. Eslinger

M. J. Fayer

E. J. Freeman

M. D. Freshley

G. W. Gee (10)

T. J. Gilmore

D. G. Horton

J.M. Keller

C. T. Kincaid

G. V. Last

P. E. Long

W. J. Martin

P. D. Meyer

C. J. Murray

S. M. Narbutovskih
K6-81

K9-14

E6-35

P8-37

K6-80

K9-33

K9-33

H0-21

K9-33

K6-81

K6-81

K9-36

K9-33

K6-81

K9-33

K3-54

BPO

K6-81

K6-96
No. of

Copies

\section{ONSITE}

Mart Oostrom K9-33

W. E. Nichols K9-33

S. P. Reidel K6-81

M. L. Rockhold K9-33

R. J. Serne K6-81

C. E. Strickland K9-36

M. D. Sweeney K6-81

M. J. Truex K2-10

A. L. Ward (10) K9-33

K. Waters-Husted K9-33

M. White K9-36

B. A. Williams $\quad$ K6-81

M. D. Williams K9-36

S. B. Yabusaki K9-36

J. M. Zachara K8-96

F. Zhang K9-33

Technical Report Files (2) 